\title{
PFAS Environmental Pollution and Antioxidant Responses: An Overview of the Impact on Human Field
}

\author{
Marco Bonato ${ }^{\dagger}$, Francesca Corrà ${ }^{\dagger}$, Marta Bellio, Laura Guidolin, Laura Tallandini ${ }^{\dagger}$, Paola Irato * \\ and Gianfranco Santovito *(D) \\ Department of Biology, University of Padova, 35131 Padova, Italy; marco.bonato@unipd.it (M.B.); \\ francesca.corra@unipd.it (F.C.); marta.bellio@unipd.it (M.B.); laura.guidolin@unipd.it (L.G.); \\ laura.tallandini@unipd.it (L.T.) \\ * Correspondence: paola.irato@unipd.it (P.I.); gianfranco.santovito@unipd.it (G.S.) \\ + These authors contributed equally as first authors.
}

Received: 4 October 2020; Accepted: 27 October 2020; Published: 30 October 2020

\begin{abstract}
Due to their unique properties, perfluorinated substances (PFAS) are widely used in multiple industrial and commercial applications, but they are toxic for animals, humans included. This review presents some available data on the PFAS environmental distribution in the world, and in particular in Europe and in the Veneto region of Italy, where it has become a serious problem for human health. The consumption of contaminated food and drinking water is considered one of the major source of exposure for humans. Worldwide epidemiological studies report the negative effects that PFAS have on human health, due to environmental pollution, including infertility, steroid hormone perturbation, thyroid, liver and kidney disorders, and metabolic disfunctions. In vitro and in vivo researches correlated PFAS exposure to oxidative stress effects (in mammals as well as in other vertebrates of human interest), produced by a PFAS-induced increase of reactive oxygen species formation. The cellular antioxidant defense system is activated by PFAS, but it is only partially able to avoid the oxidative damage to biomolecules.
\end{abstract}

Keywords: antioxidant defenses; human health; environmental pollution; oxidative stress; epidemiology; perfluorinated substances; reactive oxygen species; toxicology

\section{Introduction}

Oxygen $\left(\mathrm{O}_{2}\right)$ is an essential molecule for the life of many organisms present on Earth as it participates in all the oxidation reactions that characterize aerobic cell metabolism, being the final acceptor in the electron transport chain that leads to the formation of ATP at the mitochondrial level. During these processes, $\mathrm{O}_{2}$ is reduced to water, but some electrons can react directly with the molecule, forming intermediates called reactive oxygen species (ROS) [1].

It has been calculated that about $3 \%$ of the $\mathrm{O}_{2}$ used by the cell is improperly converted into ROS [2] but this rate of formation can easily increase in numerous physiological and pathological conditions such as physical activity, aging, cardiovascular disease, and cancer. Other factors favoring the formation of ROS are mechanical and thermal stress, exposure to ionizing radiation, hypoxia, and high partial pressure of $\mathrm{O}_{2}$, biotransformation of xenobiotic compounds, such as toxins, drugs, and chemical contaminants of various kinds [3-6].

Among contaminants of emerging concerns a particular interest is currently focused on Persistent Mobile Organic Contaminants (PMOC), which are highly polar compounds and likely to move and persist in the water cycle and in raw waters used for drinking water production and irrigation. Since they degrade very slowly, PMOC are extremely mobile in aqueous medium and their preferable 
accumulation matrix is water (including water contained in the biological tissues). For this reason, the exposure to PMOC can lead to serious health effects, which in many cases cannot be adequately assessed because the lack of monitoring and eco-toxicological data [7]. This is the case of the most important family of PMOC, which are the perfluorinated substances (PFAS).

The cytotoxic effects of ROS include peroxidation of membrane lipids with increasing malondialdehyde levels through oxidation of polyunsaturated fatty acids, alteration of redox balance, enzyme inactivation, and DNA damage [8,9]. All living organisms respond to a high presence of ROS by increasing the expression of antioxidant enzymes and many other molecules that are elements of the defense and repair toward oxidative damage [10]. Enzymatic antioxidants include proteins such as superoxide dismutase (SOD) [11,12], catalase (CAT) [13], glutathione peroxidase (GPx) [14], peroxiredoxins (Prdx) [15,16], and methionine sulfoxide reductases (Msr) [17]. These enzymes represent a first line against ROS, but do not guarantee complete coverage from the risk of oxidative stress because some compounds, generated by their reactions, are still reactive and potentially cytotoxic, such as the hydrogen peroxide $\left(\mathrm{H}_{2} \mathrm{O}_{2}\right)$ produced by SOD. A joint and coordinated action of the various enzymatic components is therefore necessary to prevent further intracellular damage. The class of non-enzymatic antioxidants is represented by low molecular weight molecules rich in thiol groups such as metallothioneins $[18,19]$ and glutathione (GSH), which are biosynthesized by the cell. The latter, in addition to being a substrate for GPx, can act directly as a scavenger of ROS during the detoxification processes of $\mathrm{H}_{2} \mathrm{O}_{2}$ and lipid hydroperoxides. There are also other compounds that are usually acquired through the diet such as ubiquinol, provitamin A, vitamins C, E, B6, B9, B12 and P, selenium, $\beta$-carotenoids, and polyphenols [20]. These molecules are mostly considered chain-breaking antioxidants since they interrupt the autocatalytic action of radical reactions, blocking the propagation of oxidative damage.

PFAS are a group of more than 4600 man-made chemicals with little or no data available on their biological effects [21]. The most studied and well-known PFAS are perfluorooctanoic acid (PFOA), perfluorooctane sulfonic acid (PFOS) perfluorohexanesulfonic acid (PFHxS) and Perfluorononanoic acid (PFNA) [22]. PFAS have unique physicochemical properties, due to their dielectrical properties, resistance to heat and chemical agents, low surface energy and low friction properties, and to their high stability thanks to the carbon-fluorine bond. These properties give to the substance versatility, strength, resilience, and durability, and that is why their use is convenient in a multiplicity of technical applications [23]. It has to be emphasized that to this date there is no evidence of biodegradation of perfluorinated carboxylic acids (PFCAs) and perfluorinated alkane sulfonates (PFAS) [24-27] that, in addition to their direct production, can also be the result of the terminal biodegradation products of perfluorooctanesulfonyl fluoride-based and fluorotelomer-based products [28]. In fact, the extensive uses of PFAS, together with their persistence, resulted in a worldwide dispersion, including in the biosphere, with a global distribution in living organisms like fish, birds, mammals, and humans [29].

This review summarizes the available data on the presence of PFAS in the environment and the effects they have on human health, with particular reference to the condition of oxidative stress. For this purpose, we have included the results of epidemiological studies, and those of in vitro and in vivo research correlating PFAS exposure and oxidative stress effects (in mammals as well as in other vertebrates of human interest).

\section{PFAS and Their Distribution in the Environment}

PFAS are a chemical family of compounds that have been produced since late 1940s [30]. They are found nowadays worldwide; they have been detected in oceans, across continents and in remote parts of the globe [31] including the North and South Pole [32-38], with several ecosystems affected in the USA, China, Africa, and Europe [39-47]. Their presence has been recorded in several different matrices, from the aquatic system to flora and fauna [48]. They are used in multiple industrial and commercial applications such as water repellent on clothing, leather, cosmetics, cookware, and paper, as well as being used as surface tension lowering agents in firefighting foam $[49,50]$, due to their unique 
properties provided by the extreme strength of $\mathrm{C}-\mathrm{F}$ bonds and their surfactant nature [51]. Recent studies have shown that some PFAS are toxic for both animals and humans [52]. Among the most common PFAS found in the environment (Table 1), PFOA and PFOS are considered some of the most widespread organic pollutants for biota and humans [44,53-57]. In addition, they are highly mobile once introduced to the aquatic environment [58] and are not removed by conventional wastewater treatment $[59,60]$.

Table 1. A list of the most common perfluorinated substances (PFAS) with their applications and properties [31].

\begin{tabular}{|c|c|c|c|c|}
\hline PFAS & Use & Structure & $\begin{array}{l}\text { Molecular } \\
\text { Weight }\end{array}$ & $\begin{array}{l}\text { Confirmed } \\
\text { Toxic Effects }\end{array}$ \\
\hline PFBA & synthetic chemistry & & 214.04 & unknown \\
\hline PFPeA & $\begin{array}{l}\text { breakdown product of stain and } \\
\text { grease-proof coatings on food } \\
\text { packaging, couches, carpets }\end{array}$ & & 264.05 & $\begin{array}{l}\text { yes } \\
{[61]}\end{array}$ \\
\hline PFHxA & unknown & & 314.05 & $\begin{array}{l}\text { yes } \\
{[62]}\end{array}$ \\
\hline PFHpA & $\begin{array}{l}\text { breakdown product of stain and } \\
\text { grease-proof coatings on food } \\
\text { packaging, couches, carpets }\end{array}$ & & 364.06 & $\begin{array}{c}\text { yes } \\
{[63-65]}\end{array}$ \\
\hline PFOA & $\begin{array}{l}\text { water and oil repellant in fabrics } \\
\text { and textiles, food packaging }\end{array}$ & & 414.07 & $\begin{array}{c}\text { yes } \\
{[66-68]}\end{array}$ \\
\hline PFNA & $\begin{array}{l}\text { surfactant for synthesis of } \\
\text { textiles and polymers }\end{array}$ & & 464.08 & $\begin{array}{c}\text { yes } \\
{[61,69-71]}\end{array}$ \\
\hline PFDA & $\begin{array}{l}\text { breakdown product of stain and } \\
\text { grease-proof coatings on food } \\
\text { packaging, couches, carpets }\end{array}$ & & 514.08 & $\begin{array}{c}\text { yes } \\
{[72,73]}\end{array}$ \\
\hline PFUnA & unknown & & 564.09 & $\begin{array}{l}\text { yes } \\
{[74]}\end{array}$ \\
\hline PFDoA & unknown & & 614.1 & $\begin{array}{c}\text { yes } \\
{[75-77]}\end{array}$ \\
\hline PFBS & stain repellant & & 300.1 & $\begin{array}{l}\text { yes } \\
{[78]}\end{array}$ \\
\hline PFHxS & surfactant for textiles & & 400.11 & unknown \\
\hline PFOS & firefighting foam, textiles & & 500.13 & $\begin{array}{c}\text { yes } \\
\text { [79-81] }\end{array}$ \\
\hline
\end{tabular}

Contamination of agricultural soil with PFAS can occur as a result of direct soil contamination, e.g., by fluorochemical industrial plants [82] or aqueous film-forming foams [83] through the use of biosolids [84] or contaminated irrigation water [31,85]. Consumption of contaminated food and drinking water is regarded as the main pathway of human exposure [86,87], especially the consumption of fish, meat, and eggs [88]. Several studies have examined the risks associated with PFAS exposure 
through contaminated food and water [89]. Drinking water may also be a dominant exposure pathway, if the water source is situated in a PFAS-contaminated area [90], but other possible pathways are summarized in Figure 1.

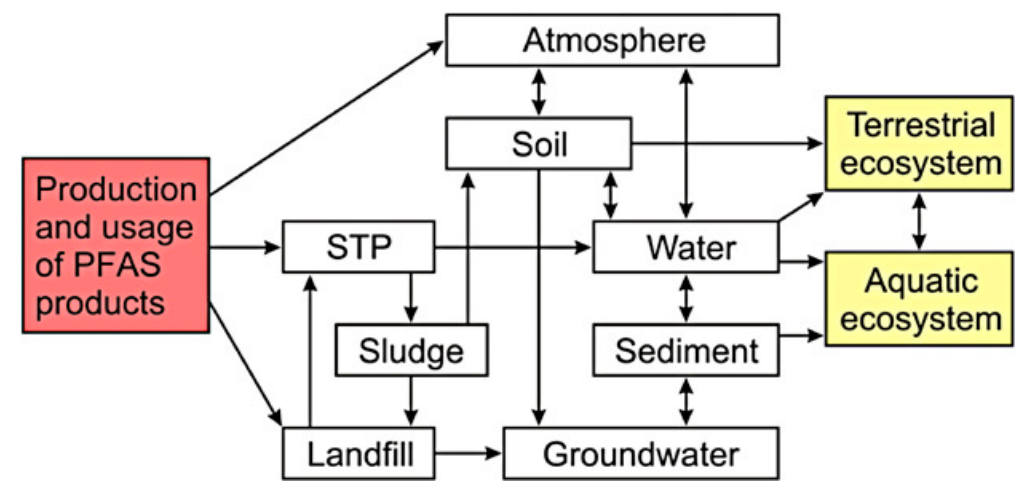

Figure 1. Pathways of PFAS into the environment and their fate. Adapted from Ahrens [53]. $\mathrm{STP}=$ sewage treatment plant.

\subsection{First Case: The USA}

PFOA is found at low levels in the serum of most people living in the United States, with higher levels observed in occupationally exposed workers [16,91]. PFOA was reported to induce liver, testes, and pancreatic tumors in male rats over a 2-year period [92]. Because of PFOA long half-life, potential environmental persistence, and possible toxicity in human, there is a rising concern about whether it might be associated with human cancers [93]. Most previous human studies on the association between PFOA and cancer concerned mortality studies of occupationally exposed workers with few cancer deaths. One study has followed workers employed at a Minnesota PFOA production plant between 1947 and 1997 [94] and the results show that there are positive trends for prostate and pancreatic cancer across job categories with increasing PFOA exposure, but estimates were based only on 16 and 13 deaths, respectively [95]. A second mortality study has followed workers who had been employed at any time between 1948 and 2002 at the West Virginia DuPont Washington Works plant [96]. Steenland and Woskie [97] have recently updated this study and reported a significant increase in kidney cancer mortality with increasing estimated cumulative PFOA serum concentrations based on 12 kidney cancer deaths. We must remember that the DuPont chemical plant in Washington, West Virginia, began using PFOA in its manufacturing process in 1951. The plant began to release PFOA into the Ohio River and in the air in the 1950s, peaking in the 1990s, and decreasing emissions after 2001. PFOA emitted from the plant entered the groundwater, which was the public drinking water source [95]. Moreover, according to a 2004 study by ChemRisk Inc. (San Francisco, CA, USA), an industry risk assessor, between 1951 and 2003, the Dupont plant in Washington Works, West Virginia released more than 1.7 million pounds of $\mathrm{C} 8$ into the environment. This has led to an increase of the average PFOA blood concentrations of $32.9 \mathrm{ng} / \mathrm{mL}$ in the population inhabiting the six counties near the Dupont Washington Works plant [98] compared to the average PFOA blood concentrations found by the National Health and Nutrition Examination Survey 1999-2000 of $5.2 \mathrm{ng} \mathrm{mL}^{-1}$ [91]. Based on all these data, Barry et al. [95] conclude that PFOA exposure is positively associated with kidney and testicular cancer in this Mid-Ohio Valley population.

\subsection{European Situation}

Perfluorinated compounds (PFCs) are used to manufacture coatings for cookware and clothing, stain resistant carpets, food packaging, firefighting foams, paints, and adhesives, with additional uses in the photo, electronics, and aerospace industries [99]. Moreover PFAS-contaminated groundwater has been inadvertently used as drinking water supply in Sweden, Germany, the United Kingdom and Italy [100-103]. Within continental waters, large lakes present special features because of their 
physical characteristics, especially a long residence time, and the services they can provide to human populations. In fact, they are the main source of drinking water for residential populations [104]. Concerns about PFCs, particularly PFOS and PFOA are growing because they are globally distributed, environmentally persistent, bioaccumulative, and potentially harmful $[105,106]$. Up until 2002, approximately $4500 \mathrm{t}$ of PFOS-related chemicals were produced worldwide annually, with a total historical production of about 100,000 tons [35]. From 2002 some users moved to alternative fluorine-based products, i.e., perfluorobutane sulfonate (PFBS) has been introduced as an alternative for PFOS [107]. This compound has recently been listed as chemical for regulation within the Stockholm Convention [108] and was banned in the European Union in 2007 for most applications [109]. In 2009, it was added as Annex B to the Stockholm Convention on Persistent Organic Pollutants (POPs). In 2015, more than 200 scientists signed the Madrid Statement [110], requiring the international community to cooperate in limiting the production and use of PFAS, and raising concern about the new short-chain perfluorinated compounds. PFOA was listed on Annex A of the Stockholm Convention in 2019 [111] and PFHxS has been proposed for listing under the Stockholm Convention and is currently under review [112]. In Europe, as well as in USA, a single European drinking water regulation for both PFOA and PFOS has not been established yet, and each member of European Union has a different regulation. The UK Health Protection Agency (HPA) set the PFAS levels in drinking water at $0.3 \mathrm{mg} \cdot \mathrm{L}^{-1}$ for PFOS and $10 \mathrm{mg} \cdot \mathrm{L}^{-1}$ for PFOA [113]. Other Regulatory Institutes set limits in terms of tolerable daily intake (TDI). The European Food Safety Authority (EFSA) indicated $0.15 \mathrm{mg} \cdot \mathrm{kg}^{-1}$ body weight (bw) for PFOS and $1.5 \mathrm{mg} \cdot \mathrm{kg}^{-1} \mathrm{bw}$ for PFOA as the limit [114]. The German Commission for Drinking Water [115] set the limit to $0.1 \mathrm{mg} \cdot \mathrm{kg}^{-1} \mathrm{bw}$ for both PFOS and PFOA. In Italy, on January 2014, the Italian National Health Institute (ISS) indicated the following performance limit: $\mathrm{PFOS} \leq 30 \mathrm{ng} \cdot \mathrm{L}^{-1} ; \mathrm{PFOA} \leq 500 \mathrm{ng} \cdot \mathrm{L}^{-1}$; and other PFAS $\leq 500 \mathrm{ng} \cdot \mathrm{L}^{-1}$.

\subsection{Veneto Region}

The Po valley has a strong agricultural history and is responsible for the success of the Veneto region as one of the most significant producers of fruits, vegetables, cereals and wine in Italy and Europe [116], making it among the most important economic sectors in the region. In general, Italy has the highest use of water for agricultural purposes in Europe, about $50 \%$ of which is in the form of surface and groundwater [117]. In 2013, a large-scale contamination of PFAAs was discovered in the Veneto region, Northern Italy, as a consequence of the emissions of a fluorochemical plant in the province of Vicenza [118] showed in Figure 2. The municipalities considered as "contaminated areas" were selected from the Veneto Region report of 2015, which listed municipalities with PFOS, PFOA, and the other PFAS exceeding at least one of the ISS performance limits of $30 \mathrm{ng} \cdot \mathrm{L}^{-1}$ for PFOS, $500 \mathrm{ng} \cdot \mathrm{L}^{-1}$ for PFOA and $500 \mathrm{ng} \cdot \mathrm{L}^{-1}$ for the other PFAS in drinking water but did not report PFAS concentration level [103]. The white areas were not selected in the Veneto Region Report.

In the Vicenza province, concentrations of PFOA up to $20 \mu \mathrm{g} \cdot \mathrm{L}^{-1}$ were detected in the groundwater, $3.4 \mu \mathrm{g} \cdot \mathrm{L}^{-1}$ in surface waters and $7.9 \mu \mathrm{g} \cdot \mathrm{L}^{-1}$ in spring waters of the Vicenza province were detected, with measured peaks up to $700 \mu \mathrm{g} \cdot \mathrm{L}^{-1}$ in industrially contaminated wells in the area [119]. According to Pitter et al. [103] residents of a vast territory of the Veneto Region have been inadvertently exposed to drinking water containing high concentrations of PFAS. Through public waterworks, contaminated groundwater was provided to roughly 140,000 people. This contamination is one the largest cases of high residential exposure to PFAS ever reported, and it resembles in origin, extent, and characteristics the one that occurred in the Mid-Ohio Valley, in the United States [98]. PFOA reached the highest concentrations both in drinking water and serum, consistent with previous reports from the Mid-Ohio Valley [98]. A recent study has showed that communities living near PFOA chemical plant have higher risk of diabetes, cerebrovascular diseases, myocardial infarction and Alzheimer's disease in both sexes and for kidney cancer, breast cancer, and Parkinson's disease in females [120]. Moreover, the effects of PFAS as endocrine disruptors are manly connected with hormonal unbalances, fertility 
decrease, birth outcomes defects [121], and alterations of many biochemical parameters, not inducing fatal outcomes [122].

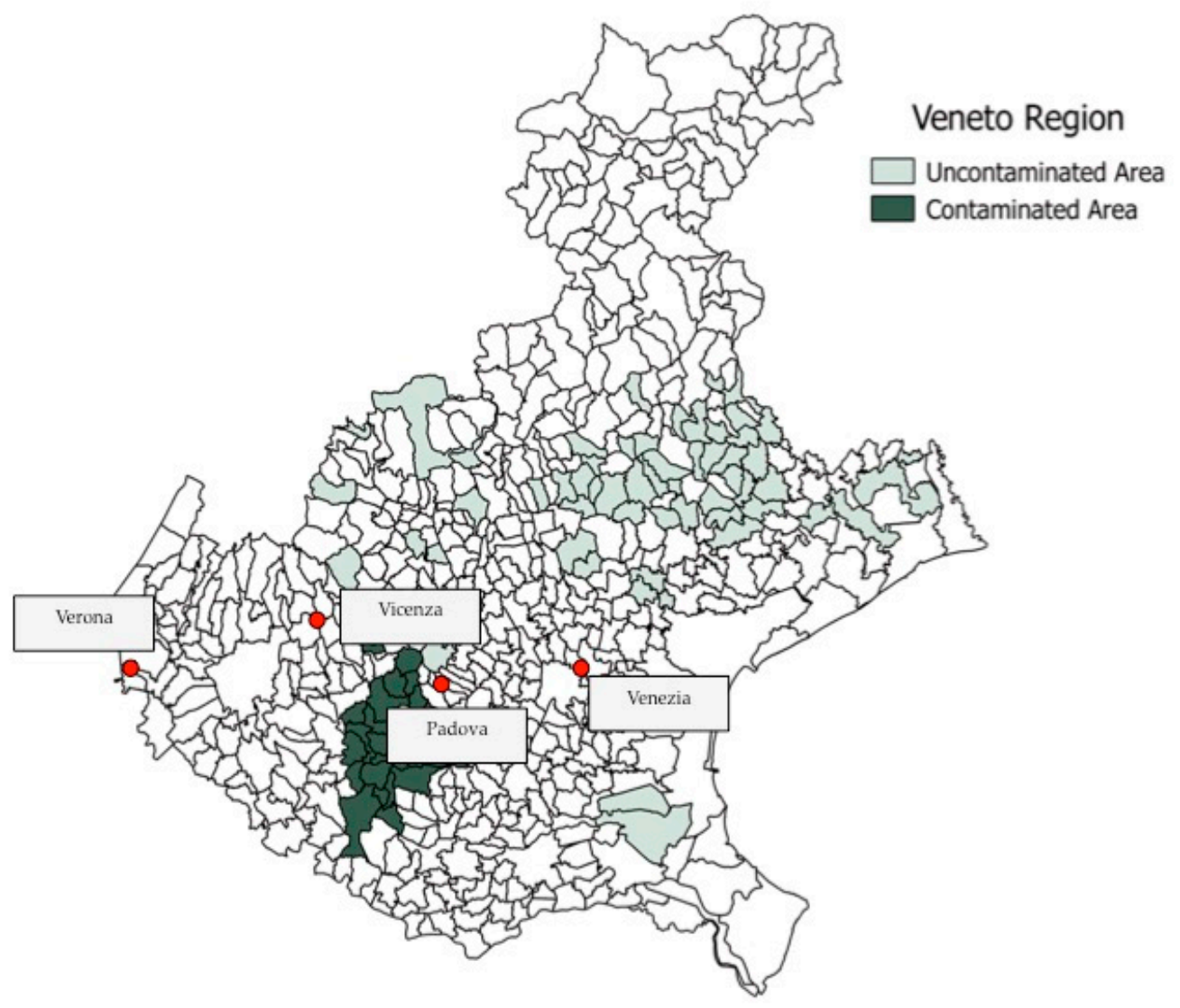

Figure 2. Contaminated (in dark grey) and uncontaminated (in light grey) municipalities on the basis of the Italian National Health Institute (ISS) performance limits in drinking water in the Veneto region. In many municipalities (in white) no analyzes were carried out [120].

\section{Epidemiological Studies}

In order to describe the interactions with the human population, a large number of biomonitoring, basic mechanistic and epidemiological studies have been increasingly developed worldwide since the early 2000s when the PFAS were found to be environmentally ubiquitous [10,123] but especially, during the last 10 years [124]. Before, the pioneristic works accomplished by Taves in the 1960s and in the early 1970s [125-128] about the presence of PFAS in human tissues, had little resonance. Studies on the PFAS presence and health status in people working in PFCs plants were also performed. Ubel et al., found higher than normal levels of organic fluorine in the blood of workers exposed to fluorochemicals in an industrial environment without ill health effects attributable to exposure to fluorochemicals [129]. The analysis of clinical examination data from PFOA production workers found clear associations between increased PFAS concentrations in the blood and decreased leukocyte counts, suggesting that cell-mediated immunity could be affected by PFOA $[130,131]$. In a study conducted on the mortality rates of workers exposed to PFOA no associations were seen in male employees between any cause of death and length of employment, but a standardized mortality ratio of 2.03 for prostate cancer was seen in exposed males compared to 0.58 in non-exposed males. A weak but significant positive association was seen between exposure and prostate cancer risk and the risk increased with the length of employment. A positive association was seen as well between age at first employment and prostate cancer mortality [132]. In a subsequent study, 115 occupationally exposed workers were examined for the cross-sectional associations between PFOA and hepatic enzymes, 
lipoproteins, and cholesterol. The findings indicated that no significant clinical hepatic toxicity was observed in the study at those PFOA levels, leading to the possibility that PFOA may modulate the previously described hepatic responses to obesity and xenobiotics [133]. Additionally, in 1976, 3M began testing for-and finding-PFOA in workers' blood (men and workers pregnant women) always with internal reports. Only in 1999, 31 years after Taves' initial discovery, 3M communicated with a Report to U.S. EPA the data about PFAS accumulation in humans [134]. Thus, it appeared also that from the 1950s until the early 2000s, the chemical plant, DuPont Washington Works, in southwest Parkersburg, WV, USA, released PFOA into the air and in the Ohio River. At that time it was named "C8" as PFOA, perfluorooctanoic acid, chemical formula $\mathrm{C}_{8} \mathrm{HF}_{15} \mathrm{O}_{2}$, is constituted by a chain of eight carbons, seven of them saturated with 15 fluorines, and the eighth in form of carboxylic acid (Table 1). Thanks to the emissions, PFOA reached drinking-water supplies by entering the groundwater where it was detected in six districts near the DuPont plant in 2002. This event gave rise to the famous class-action lawsuit done against Dupont by the residential population. Approved in February 2005 by West Virginia Circuit Court the class action obtained, as well as the carrying out of a water supply clean-up, the conduction of a biomonitoring study (the C8 Health project) and the establishment of the C8 scientific panel for the subsequent epidemiological health evaluations.

\subsection{The C8 Health Project}

As introduced above, the C8 health project, conducted between August 2005 and July 2006, collected interviews and blood samples, from about 69,000 people living near the $3 \mathrm{M}$ plant through a biomonitoring study. The mean levels for serum PFOA resulted 500\% higher than previously reported for a representative American population [91,98,135]. On the basis of the biomonitoring survey and the scientific data available at that time, the C8 scientific panel developed an important series of exposure and health epidemiological studies during 2005-2013, in the Mid-Ohio Valley communities, potentially affected by the releases of PFOA (or C8) emitted since the 1950s from the Washington Works plant in Parkersburg, West Virginia. Six probable cause-effect links were found between $\mathrm{C} 8$ and pregnancy-induced hypertension/preeclampsia, autoimmune ulcerative colitis, thyroid disease, teste and kidney cancers, and increased plasma cholesterol levels. The C8 panel study concluded that there was an absence of a probable link between exposure to C8 (PFOA) and chronic kidney disease, liver disease, osteoarthritis, Parkinson's disease, autoimmune diseases other than ulcerative colitis (i.e., rheumatoid arthritis, lupus, type1 diabetes, Crohn's disease, or multiple sclerosis), common infections, including influenza, in children or adults, neurodevelopmental disorders in children, including attention deficit disorders and learning disabilities, asthma or chronic obstructive airways disease, stroke, and Type II diabetes. [136]. The C8 Science Panel has completed its work in 2013, and no longer exists. Oxidative stress problems were not studied in the C8 panel activities. The discussion on PFAS risks, strongly reinforced after the Ohio accident, the results of $\mathrm{C} 8$ health project and the links between PFOA and human health detected by the $\mathrm{C} 8$ scientific panel, gave rise to three important statements:

- Helsingør Statement on Poly- and Perfluorinated Alkyl substances (PFAS) [137];

- The Madrid Statement on Poly- and Perfluoroalkyl Substances (PFAS) [110];

- Zürich Statement on Future Actions on Per- and Polyfluoroalkyl Substances (PFAS) [138].

- These statements increased the consciousness of researchers, managers and communities on the PFAS issues.

Plenty of studies were developed in the following years both by the C8 Panel scientists with collaborators (http://www.c8sciencepanel.org/publications.html, for a total of 29 additional papers up to Jan 2020) and by a large number of researchers worldwide, looking to enhance the knowledge about the risk of PFAS on human health. 


\subsection{Studies after the C8 Health Project and Panel}

In the following years the cause-effect links highlighted by the C8 panel were confirmed and other correlations were also studied. However, due to the intrinsic difficulties in developing epidemiological significant data on human pathologies, a major part of the studies was focused on the PFAS concentrations in cohorts of residential exposed populations. Limited information have been collected on PFAS accumulation in solid human tissues (e.g., adipose and liver). The major part of the studies reported data on PFAS levels in blood serum and breast milk and were mostly dedicated at the presence and concentrations of PFOA and PFOS, but other studies included also PFBS, PFHxS, PFDS, PFBA, PFPeA, PFHxA, PFHpA, PFNA, and PFDA.

In the U.S. general population, PFAS were detected in more than $99 \%$ of all serum samples from the 2009-2010 National Health and Nutrition Examination Survey (NHANES) [139]. The concentrations of PFOS and PFOA, the two most widely detected PFAS, showed a decrease in many countries following the drop in production after the year 2000 [140] but exposure to other short-chain and also other long-chain PFAS are increasing in U.S. as in many countries.

Investigation on plasma samples, collected in Sweden in the years between 1987 and 2007, showed PFOS and PFOA blood concentrations peaking around 2000 and then declining, while increasing PFHxS, PFNA, PFDA, and PFUnDA concentrations within the overall study period [141]. This tendency was confirmed by reported increasing concentrations of PFBS, PFHxS, PFNA, and PFDA in Swedish blood serum samples in a cohort of 413 primiparous women between 1996 and 2010 [142]. This is also in line with the study from Gebbink et al. [143] reporting increasing trends in pooled serum samples from Sweden for PFHxS, PFNA, PFDA, PFUnDA, PFODA, and PFTrDA and with analyses of serum samples from Norway from 1979 to 2007 that documented decreasing concentrations of PFOS and PFOA from 2001 onwards, whereas PFNA, PFDA, and PFUnDA were increasing, while for PFHxS and PFHpS no trend could be observed [144].

In Denmark, the concentrations of seven PFAS (PFHXS, PFHpS, PFOS, PFOA, PFNA, PFDA, and PFUnDA) decreased in the period 2008-2013 [145]. Schröter-Kermani et al. [146] reported decreasing concentrations from 2001 onwards for PFOS, from 2008 for PFOA and from 2005 for PFHxS and stable concentrations for PFNA in samples from Germany from 1982 to 2010. Also, Yeung et al. [147,148] observed decreasing concentrations for PFOA after 2000, but increasing concentrations for PFNA, PFDA, and PFUnDA. Decline in perfluorooctane sulfonate and perfluorooctanoate serum concentrations were reported in an Australian population from 2002 to 2011 [149]. In North Rhine-Westphalia, Germany, where 40,000 inhabitants were exposed to PFAS-contaminated soil conditioners used on fields, a cross-sectional study assessed the levels of PFAS contamination in 170 children (5-6 years of age), 317 mothers (23-49 years), and 204 men (18-69 years) and found that PFAS concentrations in blood plasma of children and adults exposed to contaminated drinking water were increased 4-to 8-fold compared with controls [150]. In Japan and Korea, PFOS was detected in human serum samples collected from 1994, 2000, 2003-2004, and 2007-2008 [151,152] with significant higher levels $(p<0.01)$ in samples from the urban region than the rural region, and with gender related discrepancies for significantly higher $(p<0.05)$ concentrations of PFOS in males than females. Higher PFOS concentrations were similarly observed in urban and rural zones in China, with significantly higher concentrations in males than females $[153,154]$.

In Italy, a study by Ingelido et al. [155] looked at PFAS biomonitoring data on blood samples to characterize the extent of exposure to PFCs in groups of the Italian general population residing in two different urban location. Analyses were carried out on blood samples collected in 2008 from 230 subjects residing in Rome, in the Lazio region, Central Italy (182 subjects), and in Brescia, an industrial town located in the Lombardia region, Northern Italy (48 subjects). PFOS and PFOA were detected and quantified in all samples. PFOS concentrations ranged from $0.06 \mathrm{ng} \cdot \mathrm{g}^{-1}$ to $29.6 \mathrm{ng} \cdot \mathrm{g}^{-1}$, PFOA concentrations from $0.22 \mathrm{ng} \cdot \mathrm{g}^{-1}$ to $51.9 \mathrm{ng} \cdot \mathrm{g}^{-1}$. The medians, geometric means, and arithmetic means were 6.31, 5.77, $6.86 \mathrm{ng} \cdot \mathrm{g}^{-1}$ for PFOS and 3.59, 3.32, and $4.15 \mathrm{ng} \cdot \mathrm{g}^{-1}$ for PFOA, respectively. The whole age range was 20-65 years, shared in three subgroups, $26-35,36-50$, 
and 51-65. Overall, PFOS concentrations were consistently higher than those of PFOA in all age groups. Concentrations of PFOA and PFOS were higher in males than in females across all age groups. This agrees with studies carried out in the USA [91,156], Australia [157], China [153], Japan [158], and Germany $[159,160]$. The strong correlation observed between PFOS and PFOA concentrations is in line with observations reported in other studies [135,160-162]. The observed correlation could be partly due to the uptake of both compounds from common sources or pathways (food and migration from food packaging, drinking water, indoor dust) [157,163-165]. Age-dependence of PFC concentrations is plausible to be related to the persistence and potential for bioaccumulation [29] of these chemicals, associated with conditions of constant exposure. The concentrations measured in the study, resulted to be among the lowest observed worldwide, and they were comparable with those observed in a group of subjects (50 adult donors, 42 males, and 8 females) enrolled in the town of Siena, Tuscany, Central Italy, in 2001 [162], and were confirmed by a later work realized within the WomenBioPOP project in six Italian regions [166].

One-third of households in Ronneby, Sweden (28,000 inhabitants), were supplied with drinking water contaminated with PFAS from firefighting foams used in a nearby airfield [167]. After the elimination, in 2013, of the contaminated drinking water supply, for two years (2014-2016) a total of 3418 people from Ronneby participated in the study and a reference group of 242 subjects from a nearby unexposed municipality (Karlshamn) was also examined in 2016. In that way was possible to evaluate the half live of different PFAS, the median value of the remaining half-lives for PFHxS was 5.5 years (5-95\% range: 3.0-9.2 years). For PFOS, the median half-life was 3.5 years (5-95\% range: 2.2-6.2 years). The median half-life for PFOA was 2.7 years (5-95\% range: $1.8-5.1$ years). Serial analyses of serum samples from former $3 \mathrm{M}$ production workers after retirement suggested elimination half-lives for long-chain PFAS to be three years (PFOA) and five years (PFOS). Declines in serum-PFOA concentrations after elimination of the water contamination suggest a median elimination half-life of 2.3 years, thus confirming the persistence of PFAS in the human body.

The case of the impressive Water Contamination by PFAS in the Veneto region, [118,168,169], principally ascribed to the Rimar-Miteni (RM) plant in Trissino-Vicenza led the Region Administration to design an ongoing health surveillance plan for people resident in the PFAS Impacted Area $(21+9$ Municipalities) in order to aid in the prevention, to get early diagnoses and treatment for some of the chronic disorders with epidemiological evidence of association with PFAS exposures, i.e., dyslipidemia, hyper-tension, diabetes mellitus, liver dysfunction, metabolic syndrome, kidney dysfunction, and thyroid disorders. The case requires a series of epidemiological studies on the distribution and effects of PFAS.

Ingelido et al. [170], in a study dedicated to the Veneto region areas under PFAS impact, involved 507 subjects. Of these, 257 were "Exposed" ("E"), residing in Veneto Region municipalities at high PFAS exposure, and 250 "Not Exposed" ("NE"), residing in municipalities in areas at presumed PFAS background exposure. PFAS serum concentration median value of the "E" group (13.77 $\mathrm{ng} \mathrm{g}^{-1}$ ) was 8 times higher than the median value of the "NE" group $\left(1.64 \mathrm{ng} \cdot \mathrm{g}^{-1}\right)$. PFOA was the analyte that presented the larger data dispersion in the " $\mathrm{E}$ " subjects with the $\mathrm{P} 95$ value that resulted 18 times higher than the median. Males showed PFAS serum concentrations more than 3 times higher $\left(26.07 \mathrm{ng} \cdot \mathrm{g}^{-1}\right)$ than females $\left(7.88 \mathrm{ng} \cdot \mathrm{g}^{-1}\right)$, both in the "E" and the "NE" group. Differently from sex, age did not seem to strongly affect the levels of PFAS, confirming other previously reported data [171-174]. A following study in the Veneto region has been conducted on a cohort of 18,345 participants $(49.1 \%$ females and 50.9\% males) born between 1978 and 2002, i.e., 14-39 years of age at the recruitment time in the municipalities impacted by the PFAS contamination [103]. The PFAS with the highest serum concentrations were PFOA. The median serum PFOA concentration in the study $\left(44.4 \mathrm{ng} \cdot \mathrm{mL}^{-1}\right)$ was substantially higher in comparison to the concertation found in the C8 Health Project $\left(28.2 \mathrm{ng} \cdot \mathrm{mL}^{-1}\right)$ [98], and 27 times higher than the median serum level $\left(1.64 \mathrm{ng} \cdot \mathrm{mL}^{-1}\right)$ of not exposed residents of the Veneto region [170]. The major predictors of serum levels were gender, municipality, duration of residence 
in the affected area and number of deliveries. Interindividual variation of serum PFAS levels was partially explained by the considered predictors.

The long PFAS half-lives and the duration of exposure time in the exposed populations are the baseline of epidemiological studies to evaluate long-term health and mortality effects in workers and residential cohorts associated with exposure to perfluoroalkyl and polyfluoroalkyl substances. In a cohort of 5791 workers at the DuPont chemical plant in West Virginia, Steenland, and Woskie [97] found evidence of positive exposure-response trends for malignant and nonmalignant renal diseases. These results were limited by low sample size and restriction to mortality data.

Girardi and Merler [175], comparing two cohorts of workers, the first one in a PFAS production plant (the RM plant in Trissino-Vicenza), the second one devoted to the railroad material maintenance, found a clear excess of overall mortality and of mortality for liver cancer, liver cirrhosis, malignant neoplasm of lymphatic and hematopoietic tissue among the subjects working at PFAS plant or in the highest cumulative PFOA concentration category. Their findings suggest an association between PFOA exposure and the risk of mortality not previously reported. Induced tumors have been ascribed to non-genotoxic mechanisms, such as an indirect genotoxic hazard, such as the ability of PFOA to induce oxidative stress, even if recently denied in an assessment on mice [176]. However there are no doubts of toxic effects on liver experienced by the workers under study: The surveillance of the RM factory workers showed a positive association for alanine aminotransferase (ALT) and $\gamma$-glutamyl transferase (GGT) hepatic enzymes and an inverse association with bilirubin [177]. A longitudinal study [178] on a cohort of 1002 individuals from Sweden (50\% women) at ages 70, 75, and 80 in 2001-2014, confirmed these observations, showing that exposure and biological persistence to PFAS caused liver dysfunction and toxicity, measured in terms of changes in ALT and alkaline phosphatase (ALP) levels. Furthermore, PFAS with long perfluoroalkyl chains are associated with increased GGT and decreased bilirubin levels, an important antioxidant and cytoprotectant, decreased levels of which have been associated with adverse health effects, including liver dysfunction, cardiovascular disease, and the metabolic syndrome.

At the present moment, relatively few studies have investigated the associations between plasma PFAS concentrations and markers of liver function. Most of them found evidence of a relationship between PFAS concentrations and liver enzymes including ALT, ALP, and GGT. Increased ALT activity is clinically used as a marker of liver dysfunction. Concentrations of PFHpA, PFOA, PFNA, and PFOS were positively associated with the activity of ALT in a large cross-sectional study on 47,092 Mid-Ohio Valley residents with elevated PFOA concentrations due to a drinking water contamination [179]. A positive association between PFOA and ALT was also reported in an ancillary study on 30,723 Mid-Ohio Valley residents [180]. In all people falling into the third tertile of cumulative internal dose of PFOA (which exceed the lowest-observed-adverse-effect level, estimated to cause liver toxicity in experimental animals [181]) liver toxicity was actually observed [180]. The IARC Monograph on PFOA noted that liver toxicity observed in rodents has been associated with both PPAR $\alpha$-dependent and independent mechanisms. The in vitro data from human are consistent with tests on multiple molecular pathways [182]. Hepatic effects of PFOS are clearly PPAR $\alpha$-independent [176].

Looking at previous studies in animal and cell models, in which the increased oxidative stress resulted as an important response to PFC exposure [183-186], the influence of low-level environmental PFC exposure on serum metabolome was studied in a cohort of 181 adult males individuals (males, in order to avoid the periodical female endocrine changes) from the general population was studied [187]. In particular, serum samples were investigated for different PFCs concentrations and metabolome changes. PFCs species relations to ten serum biomarkers were screened based on their internal doses. Eight biomarkers (i.e., D-glucurono-6,3-lactone (DG63L), $\alpha$-carboxyethyl hydroxychromanol, arachidonic acid, hypoxanthine, oxoglutaric acid, pyroglutamic acid, tetrahydrobiopterin, and xanthine) were negatively associated with the high exposure levels and two biomarkers (i.e., deoxyarabinohexonic acid and hydroxybutyric acid) were positively associated. PFC exposure resulted associated with the disturbance in GSH cycle, TCA cycle, nitric oxide (NO) generation, and purine oxidations. In fact, 
the obtained serum metabolic biomarkers implied that the lipid metabolism, xenobiotic detoxifying, anti-oxidation, and NO signal pathways may be affected by PFC exposure in a dose dependent trends between serum pollutant residuals and metabolic biomarkers. Oxidative stress may result in a distal linkage of DG63L to ascorbate. The observed alteration of oxoglutaric acid may further support the response of DG63L to PFC-induced fatty acid oxidation via ascorbate and aldarate metabolism pathway.

\section{Mammals: In Vitro and In Vivo Studies Correlating PFAS Levels and Oxidative Stress}

A certain amount of oxidative damage takes place even under normal conditions, such as aging. Cells act to counteract the oxidant effects and to restore redox balance. Cells react by resetting critical homeostatic parameters are reset, activating or silencing genes encoding defensive enzymes, transcription factors, and structural proteins. A consequence of this action can be the accumulation of oxidation products of lipids, nucleic acids, proteins, sugars, and sterols causing cellular dysfunction [188]. Oxidative stress occurs when oxidative action of ROS is stronger than antioxidant responses of the cellular defense system, and it usually determines peroxidation of membrane lipids, DNA damage and mutations, oxidation and deactivation of proteins and enzymes, and activation of apoptotic and/or necrotic processes.

ROS production is a common denominator in many pathological conditions and can lead to severe cellular damage leading to physiological dysfunction and cell death. Oxidative stress has been observed in relation to several diseases in humans, including diabetes, atherosclerosis, cardiovascular diseases, chronic inflammatory diseases, central nervous system disorders, age related disorders, and cancer [189-192], and has been linked to a shortening of life [193].

Oxidative stress can be also induced by exposure to environmental pollutants such as dioxins and heavy metals [194,195], and a similar effect can be relevant for PFAS [196]. As mentioned above, exposure to PFOS and PFOA is known to cause an increase in ROS formation and, consequently, cellular oxidative stress (Table 2). Oxidative stress and physiological process disruption based on fatty acid similarity are widely studied mechanisms of PFAS toxicity [197].

\subsection{PFAS Affect Oxidative Stress Biomarkers In Vitro}

PFAS are suspected carcinogens and the fact that they generate oxidative stress can be a potential action mode. Hu and $\mathrm{Hu}$ [198] reported a study in which they analyzed single antioxidants enzyme activity after exposure to PFAS in hepatoma Hep G2 cells. Exposure to PFOA and PFOS resulted in an increased activity of SOD, CAT, and glutathione reductase (GR) and decreased activity of GPx and glutathione S-transferase (GST). The authors suggested that the observed changes in activities of antioxidative enzymes indicated that PFOA and PFOS may overwhelm the balance of the antioxidant system, boost the generation of ROS, impact the mitochondria, and result in the initiation of apoptosis program.

Wielsøe et al. [196] conducted a study in which the results indicate a possible genotoxic and cytotoxic potential of the PFAS in human liver cells inducting oxidative stress.

In particular, they investigated the effect on oxidative stress factors of seven long chained PFAS: PFHxS, PFOA, PFOS, PFNA, PFDA, PFUnA, and PFDoA in human hepatoma cell line (HepG2) and an exposure time of $24 \mathrm{~h}$ using concentrations from $20 \mathrm{nM}$ to $200 \mu \mathrm{M}$ (much higher than the environmental ones).

Four of the PFAS (PFHxS, PFOA, PFOS, and PFNA) showed dose-dependent increase in DNA damage determined by the comet assay. A high level of DNA lesions may lead therefore to mutagenesis, cytostatsis, and cytotoxicity [199].

Six PFAS (except for PFDoA) increased ROS generation and the increase was dose-dependent for two PFAS (PFHxS and PFUnA).

PFOA significantly decreased the total antioxidant capacity (TAC), whereas a non-significant trend in TAC decrease was observed for PFOS and PFDoA and an increase tendency for PFHxS, PFNA and PFUnA. 
Among the tested PFAS, five were PFCA and two sulfonic acids (PFSA). The two investigated PFSA (PFHxS (C6) and PFOS (C8)) both increased the DNA damage dose dependently and induced intracellular ROS generation, but none of them affected the TAC level significantly. For the five PFCA (PFOA, PFNA, PFDA, PFUnA, and PFDoA) with carbons chains containing between 8 and 12 carbon atoms, the length of the carbon chain seemed be related to some degree to all the three endpoints with the highest potency of the shortest carbon length.

PFOA increases oxidative stress and mitochondrial dysfunction that lead to apoptosis and cytotoxicity in rat $\beta$-cell-derived RIN-m5F cells [200]. These mechanisms may contribute to the effects of subchronic, elevated exposures to PFAS on thyroid hormone homeostasis, liver toxicity, and body weight observed in animal experiments $[29,181]$.

PFAS have been shown to induce adipocyte differentiation and lipid metabolism in cell culture [201]. Recent evidence from in vitro studies has further demonstrated potentially estrogenic and antiestrogenic effects of PFAS [202,203].

All these results indicate a potential genotoxicity and cytotoxicity of PFAS in human cells.

\subsection{PFAS Affect Oxidative Stress Biomarkers In Vivo}

PFAS are suspected obesogens, and the obesogenic potential of PFAS has been shown by in vitro and in vivo studies.

In vivo experiments in mice showed that PFOA induced histopathological changes in the pancreas through the increasing of oxidative stress [204].

PFAS have the ability to activate the peroxisome proliferator-activated receptor alpha (PPAR $\alpha$ ) and induce peroxisome proliferation in rodents, but the human relevance for this mode of action has been questioned [205,206].

Experimental studies and animal models have shown that PFAS can act as agonists of the PPAR $\alpha$, which might lead to liver damage $[29,207,208]$. In particular, these studies have found that PFAS activate PPAR $\alpha[65,209]$ and PPAR $\gamma$ [209-211], which regulate energy homeostasis, lipid and glucose metabolism, and adipocyte differentiation and function [212].

PPAR $\alpha$ plays a crucial role in lipid homeostasis and in the proliferation of peroxisomes, cell organelles involved in lipid metabolism and in the conversion of ROS in less harmful compounds (reduction of hydrogen peroxide). Upregulation occurs because PFOA (as a structural analogue of endogenous fatty acids) can be transported to the nucleus, where it activates PPAR $\alpha$. Consequently, peroxisomal proliferation is a process involving oxidative stress and is a specific biomarker of exposure to many xenobiotics.

\section{Oxidative Stress in Human Health Due to PFAS Pollution}

PFAS exposure has been associated with multiple adverse health effects in humans (Table 2), including perturbations in thyroid [213-215], kidney [216,217], and metabolic function [218-220]. Because, as already mentioned, PFAS are known to persist in the body and in the environment for years, biomonitoring efforts focused on highly exposed populations with long-term periods of follow up would provide invaluable information on the health risks imposed by this chemical class.

In adults PFAS interfere also with reproductive [221] and steroid hormones [222], adipokines [223], asthma and allergies [224], and maternal fatty acids [225].

In general, in adult people lung tissue is thought to accumulate the highest concentration of PFAS, although PFOS and PFOA tend to accumulate predominantly in the liver and bone structure, respectively. PFOA, PFOS, PFNA, PFDA, and PFUnA were found in all human tissues [226].

\subsection{Male Infertility}

Endocrine disruptors (EDs) are exogenous substances able to impair endocrine system; consequently, they may cause numerous adverse effects. Over the last years, particular focus has been given to their harmful effects on reproductive system, but very little is known, especially in 
males. A study of Cargnelutti et al. [227], aimed to discuss the detrimental effects of EDs exposure on fetal testis development, male puberty and transition age, searching in the existing literature. According to WHO/IPCS 2002 definition, "an endocrine disruptor (ED) is an exogenous substance or mixture that alters functions of the endocrine system and consequently causes adverse effects in an intact organism, or its progeny". Examples of these molecules are phthalates, bisphenol A (BPA), dichlorodiphenyldichloroethylene (DDE), polychlorinated biphenyls (PCBs), and, of course, per- and poly-fluoroalkyl substances (PFAS).

EDs mimic naturally occurring hormones like estrogens and androgens, and exert their toxicity by interfering with the normal hormonal homeostatic mechanisms (including pre- and postnatal development [228]) that promote growth and development of tissues, interfering with the hormonal binding to the corresponding receptor, notably the androgen receptor (AR) or the estrogen receptor (ER) [229]. Moreover, EDs exposition brings to an inflammatory response which triggers leukocytes and macrophages (present in the prostate and in seminal vesicles) to generate ROS about 100 times more than it is produced under normal conditions (just think about spermatozoa which possess numerous mitochondria in the mid-piece of the flagellum in order to produce the immense amount of energy needed for motility) [230]. Therefore, EDs may have negative effects not only on exposed individuals, but also on their offspring and on future generations.

The effects of EDs on the male reproductive system are usually attributed to the interactions of these chemicals with the normal production and/or function of steroid hormones that are responsible for the masculinization of the Wolffian ducts. Testis development during fetal life is crucial for male reproductive function in adulthood. Indeed, fetal period is critical for the regular development of the testis and is known as a period of high sensitivity to many EDs [227]. Both functions of testis (spermatogenesis and steroidogenesis) are set up early during fetal life, involving Sertoli cells development and Leydig cells differentiation. In particular, Leydig cells are responsible for testosterone production (responsible for masculinization) [227] which can be compromised by the presence of xenobiotics, as PFASs, and so altering ROS production.

In rats, PFOA does not seem to affect fetal Sertoli cells but may increase tendency of apoptosis in fetal Leydig cells. This damage seems to affect both proliferation and differentiation of stem Leydig cells or their progeny $[227,231]$. An altered redox environment is characteristic of the aging of many cell types, including Leydig cells, which steroidogenic function is regulated in part by luteinizing hormone (LH). Beattie et al. [231] study demonstrates how LH stimulation resulted in a significant increase of genes associated with stress response expression, antiapoptotic pathways and ROS production which brings to DNA damage (but also proteins and lipids). LH binds to $G$ protein-coupled receptors, thereby initiating a cascade of events that include activation of adenylate cyclase, increased intracellular cAMP levels, activation of cAMP-dependent protein kinase, phosphorylation of proteins, and transfer of cholesterol to the inner mitochondrial membrane. Superoxide anions and other ROS are produced by the mitochondrial electron transport chain during the process of oxidative phosphorylation. Leydig cells, in addition, contain cytochrome P450 enzymes that catalyze the oxidation of metabolic intermediates in the steroidogenic pathway and in doing so can leak electrons and serve as a source of free radical generation. Cells contain enzymes and other molecules that can neutralize or scavenge ROS.

Regarding PFOS, it seems to damage Sertoli cells by perturbing actin cytoskeleton in primary cultures of rodent and human and may directly inhibit pubertal development of rat Leydig cells. In humans, prenatal PFOS exposure may increase fetal steroid hormone production, although no association with cryptorchidism or hypospadias has been observed [227].

Alterations of testosterone concentrations could also have detrimental effects on ROS generation in the vascular system. In a review written by Tostes et al. [232], testosterone has been shown to increase ROS in smooth muscle cells via different cellular sources, such as activation of NAD $(\mathrm{P}) \mathrm{H}$ oxidase, mitochondria, cyclooxygenase 2 (COX-2), and xanthine oxidase. The genomic action of testosterone induces c-Src and PI3K/Akt pathways which, in turn, activates NAD(P)H oxidase and xanthine oxidase, respectively. Testosterone may also increase ROS, via its nongenomic action, through GPRC6A receptor. 
Increased ROS production may lead to migration, apoptosis, hypertrophy, and inflammation causing vascular dysfunction [232].

Darbandi et al. [230] observed that EDs, as PFCs, could induce excessive production of ROS beyond that of cellular antioxidant capacity, thus causing oxidative stress. In turn, oxidative stress negatively affects male reproductive functions and may induce infertility either directly or indirectly by affecting the hypothalamus-pituitary-gonadal axis and/or disrupting its crosstalk with other hormonal axes [233-236]. A direct effect could be the production of superoxide anions by the NADH-dependent oxidoreductase and $\mathrm{NAD}(\mathrm{P}) \mathrm{H}$-oxidase present respectively in the inner membrane of the mitochondria (present in the midpiece of spermatozoa) and in the plasma membrane $[237,238]$. In the plasma membrane of germ cells, $\mathrm{H}_{2} \mathrm{O}_{2}$ was also found, an uncharged molecule which is membrane permeable and which can lead to the production of other ROS [238]. An excessive ROS production may lead to either apoptotic or necrotic cell death [239]. On the other hand, EDs can indirectly cause the enhance of the circulating cortisol level, leading to oxidative stress induction and reducing circulating testosterone levels. Increased cortisol decreases LH secretion through crosstalk between the hypothalamus-pituitary-gonadal and hypothalamus-pituitary-adrenal axes [230]. Decreased LH concentration fails to stimulate the Leydig cells resulting in decreased testosterone production, whereas decreased FSH affect normal Sertoli cell functions. These toxicants also interfere with the cellular communications and adhesions between Sertoli-Sertoli cells and Sertoli-germ cells via the $\mathrm{PI} 3 \mathrm{~K} / \mathrm{c}-\mathrm{Src} /$ focal adhesion kinase signaling pathway that leads to reproductive dysfunction and disrupted hormonal secretion [230].

There are controversial results about these studies, but PFAS are for sure endocrine disruptors that compromise many processes and alter redox environment.

\subsection{Female Infertility}

Polycystic ovarian syndrome (PCOS), one of the main reasons of the ovarian infertility, is a common endocrine disorder in reproductive age women. In a study of Wang et al. [240] blood concentrations of ten PFAS were measured and associated with 180 infertile PCOS-cases and 187 healthy controls recruited from the Center for Reproductive Medicine of Shandong University (China). The plasma concentration of the perfluorododecanoic acid (PFDoA), 12 carbons lengths of perfluorocarboxylic acids, was associated with a significantly increased risk of PCOS-related infertility. Of course, PCOS is accompanied with many disturbances in hormone synthesis and antioxidant defense. Masjedi et al. [241] investigated the effects of vitamin D on steroidogenesis, apoptosis, ROS production and antioxidant defenses on human normal granulosa cells (N-GCs) and granulosa cells from polycystic ovaries (PCO-GCs). In particular, basal ROS production in PCO-GCs was markedly greater than that of $\mathrm{N}-\mathrm{GCs}$ (which was attenuated by vitamin D treatment) and consequently cell apoptosis was correlated with ROS production which could be enhanced by the presence of pollutants such as PFAS. Antioxidant defenses were instead compromised; indeed basal expression and activity of GPx were significantly lower in PCO-GCs than those of N-GCs.

PFOA also shows consistent binding affinity for progesterone [242] dysregulating progesteroneactivating genes in endometrial cells. This study was conducted in cohorts of 146 exposed females aged 18-21 from the Veneto region in Italy and 1080 non-exposed cohorts. The dysregulation of the genetic cascade leading to embryo implantation and endometrial receptivity was significant, a sad finding since the endometrium clearly represents an important fertility determining factor. Melatonin plays an antioxidant role in protecting luteinizing granulosa cells from ROS, therefore enhancing progesterone production in the follicle during ovulation [243]. Indeed, progesterone production can be inhibited by $\mathrm{H}_{2} \mathrm{O}_{2}$ which production can be induced by the presence of pollutants. In the end PFAS (PFOA in particular) could induce female infertility compromising progesterone production and enhancing ROS production and also interfering with progesterone hormonal activity. 


\subsection{Pregnant Women and Developmental Consequences}

ROS have both physiologic and pathologic roles in placenta, embryo, and fetus. The development of the embryo occurs in a relatively low-oxygen environment and this structure has low antioxidant capacity. As placentation progresses, there is an increased oxygen exchange with maternal blood, with an increased the cellular generation of ROS.

PFAS are bioaccumulative pollutants, and prenatal exposure to PFAS is believed to impact human fetal development and may have long-term adverse health effects later in life. Mamsen et al. [244] had monitored the concentrations of 5 PFAS molecules (PFOA, PFOS, PFNA, PFUnDA, and PFDA) in human fetus, placentas, and maternal plasma to evaluate to what extent these compounds were transferred from mother to fetus. PFAS concentration in fetal organs increase with fetal age. In maternal plasma, PFOS was detected at the highest concentrations, followed by PFOA, PFNA, PFUnDA, and PFDA, whereas in placentas and fetal organs the concentrations were greatly reduced, compared to maternal plasma.

Sagiv et al. [245] measured plasma concentrations of 4 PFAS in early pregnancy among 1645 women in Project Viva, a study of a birth cohort recruited during 1999-2002 in Eastern Massachusetts. They concluded that concentrations of early-pregnancy PFOS, PFOA, and PFNA were inversely associated, albeit modestly, with fetal growth and gestation length in Project Viva.

However, all the evaluated PFAS were transferred from mother to fetuses indicating that fetuses were systematically exposed to these compounds, even if not with the same level of danger because of these molecules pass from the mother to the fetus with different efficiencies [246-249], while another study conducted in China did not found any significant association [250].

Infant and children health is related to maternal characteristics such as maternal age and lifestyle during or before pregnancy. People may be exposed to PFAS in their living environment, through contaminated food, food packaging, and drinking water [251-258], but still many results are inconsistent.

PFAS levels varied between different maternal characteristics including maternal delivery age, pre-pregnant BMI, parity, maternal education level, smoking status, alcohol consumption history, and annual household income. Numerous epidemiological studies have reported associations between prenatal PFAS exposure and adverse health outcomes [259].

Some of these compounds are suspected to impact fetal development, and may disturb the endocrine system [260-263] or cause or pregnancy loss [264].

Prenatal exposure to PFOA has been associated with a dose-dependent decrease in birth weight [265,266], reduction in birth length [267], reductions in abdominal circumference [267], ponderal index [265], and also reduction in head circumference [265].

Prenatal exposure to PFAS has been associated with immunomodulation and may contribute to the etiology of asthma, a common non-communicable disease in children. Recently, higher serum-PFAS concentrations in childhood have been associated with increased odds of concurrent asthma [268], perhaps due to a shift towards a T-helper type 2 cell (TH2) immune response [269] as seen in allergic asthma and allergic diseases. However, other studies could not replicate this association $[224,270]$. Furthermore, measles, mumps and rubella (MMR) vaccination in early life may have a protective effect against asthma or asthma symptoms [271], an association that was previously substantiated in other analyses [272]. The protective effect is possibly due to the elicitation of a TH1-biased response [273], and it is possible that a TH1-biased response induced by MMR vaccination could suppress a PFAS induced TH2 immune response thus minimizing the effect of PFAS on asthma among MMR-vaccinated children.

Mora et al. [274] suggest that prenatal and mid-childhood PFAS exposure may be associated with modest, but somewhat conflicting changes in the lipid profile and ALT levels in children, particularly among girls. They also found that higher prenatal and mid-childhood PFOS, PFOA, and/or PFDeA concentrations were associated with some beneficial changes in the lipid profile, including slightly 
higher HDL-C, lower triglycerides (TG), and/or lower total cholesterol (TC)/HDL-C ratio, again mainly among girls.

In rodents, exposure to high doses of PFOS and PFOA during pregnancy reduced postnatal survival, birth weight, growth of the pups, and increased disturbed lactation [275].

Notably, the half-lives of PFAS in rats are few days short [276] compared to the 200 days in the cynomolgus monkey [80], and the 2.5-4.5 years in humans [277], suggesting a large difference in the elimination kinetics between species, and animal models may, therefore, only reflect the human situation to a limited extent.

\subsection{Kidney and Thyroid Disorders}

The kidney is another target of PFAS as it is involved in its excretion and it has been hypothesized that PFAS may damage kidneys via reabsorption of PFAS across the renal tubules. This reabsorption is hypothesized to occur due to renal tubule efflux transporters that actively transport PFAS back into systemic circulation, contributing to their long half lives in the human body $[278,279]$.

Although the mechanisms of toxicity are not well understood for each individual PFAS, it is possible that individual compounds impact target tissues via different modes of action. For example, peroxisome proliferator alpha (PPAR $\alpha$ ) is a suspected nuclear receptor target of PFAS and is expressed in the liver and kidney, however the extent to which PFAS activate PPAR $\alpha$ is thought to vary by carbon chain length and functional group, with some PFAS exhibiting high levels of PPAR $\alpha$ activation (e.g., PFOA) and others exhibiting none (e.g., PFDeA) [280]. It is possible that some PFAS alter kidney function via activation of nuclear receptor PPAR $\alpha$ and others may exert their effects through other toxicological mechanisms such as mitochondrial dysfunction [281]. As already said, PPAR $\alpha$ can be involved in the conversion of ROS in less harmful compounds (reduction of hydrogen peroxide) which potentially can be produce by the presence of xenobiotics like PFASs.

Toxicology studies by Stanifer et al. [282] demonstrated associations between PFAS exposure and lower kidney function and/or kidney cancer. Pharmacokinetic studies demonstrated that kidneys were major routes of elimination, with active proximal tubule transport. In several studies, PFAS exposure altered several pathways linked to kidney diseases, including oxidative stress pathways, peroxisome proliferators-activated receptor pathways, nuclear factor erythroid 2-related factor (Nrf2) pathways, partial epithelial mesenchymal transition, and enhanced endothelial permeability through actin filament modeling.

It is possible that the relationship between the thyroid hormone and glomerular filtration rate (GFR) may contribute to the associations with serum PFAS. Reduced GFR is a consequence of hypothyroidism whereas increased GFR is a consequence of hyperthyroidism [283]. It is possible that PFAS indirectly affect GFR by disrupting the thyroid, or that PFAS affect the thyroid and kidney independently, or that reverse causation stemming from thyroid disease-related alterations in GFR accounts for the associations reported by Blake et al. [278]. A combination of reverse causality with respect to GFR and true adverse effect on the thyroid could be responsible for the associations reported by the same authors

Verner et al. [284] have evaluated how much of the epidemiologic association between prenatal exposure to PFAS and reduced birth weight might be attributable to confounding by GFR. Their results suggest that GFR drives a portion of this association, but not all of it, and that its influence becomes more important with increasing gestational weeks.

\subsection{Cholesterol}

PFAS exposure may affect metabolic functions. The possible binding of PFAS to PPARs and other nuclear receptors raises concerns that PFAS may affect cholesterol levels [285]. Previous studies have reported that PFAS may elevate cholesterol levels in animals, as illustrated by the decreased TC in serum occurred in the $0.75 \mathrm{mg} \cdot \mathrm{kg}^{-1} /$ day dose group at serum PFOS levels $>100 \mathrm{ppm}$ in Cynomolgus Monkeys [80]. However, when using the animal data, the relevance between human and animal response to adverse health effects should be clarified. Given the apparent between-species differences 
in pharmacokinetics and tissue distribution of PFAS, as well as functional and structural differences in PPARs $[16,80,81,286]$, caution must be taken when extrapolating data regarding PFAS from animal studies to humans. Steenland et al. [287] suggested that higher serum PFOS was associated with higher levels of TC, LDL, and TG. Contrastingly, in a cross-sectional study conducted by Olsen and Zobel [288], PFOA was not significantly associated with TC or LDL. Thus, the association between cholesterol levels and PFAS exposure are not consistent among the human studies [289].

Positive correlations among PFOA, PFOS, and total cholesterol were addressed in both Dong et al. and Nelson et al.'s studies [290,291].

A statistically significant and positive association between self-reported high cholesterol and PFNA exposure was observed, consistent with reports that other PFAS may affect blood lipid levels [292].

Jain and Ducatman [293] hypothesized that the combination of PFAS exposure and obesity increases the risk of alteration of lipid metabolism. Lipids are the class of biological molecules most susceptible to be attacked by ROS. Oxidation occurs on the fatty acids present in cell membranes or lipoproteins and, as the number of double bonds present in the molecule increases, their susceptibility to oxidation increases as well. Peroxidation leads to the formation of secondary products such as aldehydes and ketones, recognized as toxic or carcinogenic. Following the oxidation of the thiol groups of some amino acids and the release of Fe by degradation of porphyrin rings, the proteins lose their physiological structure and consequently their functionality.

\subsection{Diabetes}

PFAS are structural homologs of fatty acids, and scientific evidence suggests that PFAS can disrupt metabolism and endocrine function [294,295]. Accumulating evidence has also suggested that PFAS may also interfere with human metabolism through PPAR independent pathways, as mentioned in the previous paragraph. As example of this is how PFOA alters expression of proteins in human liver cells that are regulated by hepatocyte nuclear factor 4a [296], which is a key regulator of lipid metabolism and gluconeogenesis $[297,298]$ as well as being involved in thyroid hormone homeostasis [299]. In particular, emerging evidence suggests that PFAS are endocrine disruptors and may contribute to the etiology of type 2 diabetes (T2D).

Several epidemiological studies have investigated the association between exposure to PFAS, diabetes incidence, and markers of both metabolism and glycemia with inconsistent results.

Sun et al. [300] have examined the associations between PFAS exposures and subsequent incidence of T2D in the Nurses' Health Study II (NHSII) and evaluated potential demographic and lifestyle determinants of plasma PFAS concentrations. After multivariate adjustment for T2D risk factors, including body mass index, family history, physical activity, and other covariates, higher plasma concentrations of PFOS and PFOA were associated with an elevated risk of T2D. Strong correlations between PFAS levels and established diabetes risk markers, such as adiponectin, insulin, or HbA1c, were not observed, although the cross-sectional nature of these correlations has excluded causal inference. These findings support a potential diabetogenic effect of PFAS exposures, especially PFOS and PFOA. Oxidative stress and estrogenic effects observed in experimental studies are among other possible modes of action that may explain the PFAS-T2D associations. In addition, it is possible that PFAS have stronger effects among individuals at a higher risk of diabetes (e.g., overweight) or during periods of weight change (e.g., growth spurts in childhood and puberty) [272,301].

Associations for markers of insulin resistance and metabolism are also conflicting across epidemiological studies. For example, in a cross-sectional analysis of a U.S. representative sample from NHANES 1999-2000 and 2003-2004, higher serum PFNA was associated with hyperglycemia but with lower risk of metabolic syndrome, while PFOA was associated with higher $\beta$-cell function, and PFOS was associated with higher insulin, HOMA-IR, and $\beta$-cell function [220]. However, an analysis limited to the 2003-2004 NHANES cycle found no evidence of an association of PFAS with HOMA-IR [291]. Similarly, in the 2007-2008 Canadian Health Measures Survey, PFOS, PFOA, and PFHxS serum concentrations were not associated with plasma insulin, HOMA-IR, or metabolic syndrome [219]. In a 
study on Taiwanese adults, only PFOS was associated with higher glucose levels post-OGTT, but PFOA, PFNA, and PFUA were inversely associated with post glucose-load measurements, suggesting a protective effect [302]. In the elderly Swedish cohort, PFOA was positively associated with the ratio of proinsulin to insulin [303].

Another study has examined adults at high risk of T2D with plasma concentrations of several PFAS utilizing higher markers of insulin resistance and $\beta$-cell function at baseline: there was no strong evidence that baseline plasma PFAS influenced trajectories of insulin resistance and $\beta$-cell function during up to $4.6 \mathrm{y}$ of follow-up [304].

Further studies are needed to elucidate whether effects of PFAS exposure may be age and/or sex dependent. Potential mechanisms underlying associations between PFAS and T2D risk are unclear.

\subsection{Platelets and Cardiovascular Desease}

The effect of ROS on platelet function in coronary heart diseases is complex and poorly defined. Oxidative stress is recognized as an important mediator of atherothrombotic events in cardiovascular diseases. It is known that ROS directly participate in the regulation of platelet activation and thrombus formation. Platelets themselves also generate ROS through several intracellular sources. However, the direct effects of ROS on platelets are reportedly varied.

De Toni et al. [305] investigated the effect of PFOA exposure on platelet function, a key player in the atherosclerosis process and in the development of acute thrombotic events. Their importance in coronary diseases and in acute coronary syndromes is indirectly confirmed by the benefit of antiplatelet agents in these disorders. Platelet reactivity is altered by a number of environmental factors, such as age, serum cholesterol, diabetes, catecholamine levels, cigarette smoking, obesity, and alcohol consumption. In addition, a role for platelets in the evolutionary phase of the atherosclerotic plaque has been suggested by the observation that platelets can promote foam cell formation even in the absence of hyperlipidemia.

In this study, PFOA accumulation in platelets, changes in platelet membrane fluidity and activation after dose-dependent exposure to PFOA were evaluated, intracellular calcium trafficking and platelets aggregation state was evaluated in 48 men living in a specific area of the Veneto region with high PFAS environmental pollution and compared with 30 low-exposure control subjects.

Platelet membrane was the major target of PFOA, whose dose-dependent accumulation was associated in turn with increased membrane fluidity. Most platelet agonists, including thrombin, ADP, and epinephrine, stimulate cell surface receptors that span the platelet membrane, representing a potential target for chemicals that induce alterations in membrane fluidity. These data let to hypothesize a major production of ROS after the interaction of PFAS with fatty acids metabolism and steroidogenic machinery, in particular interfering with NO production [187].

Exposed subjects had higher serum and platelet levels of PFOA, together with increased aggregation parameters, compared with controls. In the presence of PFOA, platelets increase their cytosolic calcium concentration. These data help to explain the emerging association between PFAS exposure and cardiovascular diseases.

\section{PFAS and Oxidative Stress in Other Vertebrates}

We wanted to dedicate this section to the PFAS-induced oxidative stress in non-human vertebrates. This choice is only apparently peculiar for a review that wants to focus on aspects related to humans, as many current scientific studies on non-human vertebrates are collecting data that may have important practical implications on human health. Certainly, most of them are using model organisms whose validity is universally recognized, among all the zebrafish (Danio rerio). But even those who study non-model animals are important, because those species constitute food products or because they are bioindicators of the environmental quality.

What emerges clearly from the literature data is that PFAS induce oxidative stress in animals. This claim is supported by chemical, biochemical, and molecular data (Table 2). 


\subsection{Chemical Data}

The chemical data concern the formation of ROS and lipid peroxidation. In vitro studies, using goldfish (Carassius auratus) lymphocytes exposed to PFOA and freshwater tilapia (Oreochromis niloticus) hepatocytes treated with PFOS or PFOA, reveal that PFAS significantly increased ROS formation rate in a dose dependent manner [184,306].

In zebrafish experimentally exposed to various doses of PFOS, ROS formation increased significantly in embryos [307,308] and in liver of adult specimens, while in gills, intestines, and brain no significant changes were highlighted [309]. The rate of ROS formation also increased in zebrafish embryos and larvae exposed to PFNA [310], and to two novel PFOS alternatives, 6:2 fluorotelomer sulfonamide alkylbetaine (6:2 FTAB) [311] and 6:2 chlorinated polyfluorinated ether sulfonate (commercial name F-53B) [312].

Lipid peroxidation is reported in fathead minnow (Pimephales promelas) embryos and zebrafish larvae in response to PFOS [307,313], in goldfish lymphocytes and freshwater tilapia hepatocytes exposed to PFOA [184,306], and in zebrafish embryos under PFOS, PFOA, and PFNA [308,314]. An interesting result was obtained in fathead minnow, where PFOA was discovered having a different effect in males rather than females, the former showing a significant increase in damaged lipids but no such change was observed in female fish [315]. These data well correlate with the increase of ROS formation rate and suggest that antioxidant defense systems are not totally able to avoid oxidative damage to macromolecules and cell structures [316].

Exposure to PFOS alternatives gave mixed results. In fact, a decrease in lipid damage was highlighted in liver and larvae of zebrafish after F-53B exposure [317,318] but there was an increase in zebrafish embryos exposed to 6:2 FTAB [311].

The data of one of few papers that does not deal with fish, in which embryonic exposure of chicken (Gallus gallus domesticus) to PFOS and F-53B at environmentally relevant concentrations, bucked this trend. The treatment did not cause oxidative damage to lipids or proteins [319].

\subsection{Biochemical Data}

Biochemical data concern the biosynthesis of GSH and the induction of antioxidant enzymes, usually expressed as cellular and tissue enzymatic activity. Very few studies analyzed GSH levels in organisms exposed to PFAS, and they exclusively performed in vitro experiments. Among those, we mention one on goldfish lymphocytes treated with PFOA [306] and one on tilapia hepatocytes exposed to PFOS or PFOA [184]. In both cases, a decrease was observed in GSH content. The authors correlated these results to the detoxifying activity of enzymes such as GPx and GST, which use this tripeptide as co-factor. However, the situation is much more complex, because we must take into account not only the oxidation of GSH in GSSG but also its biosynthesis, catalyzed by $\gamma$-glutamyl-cysteine ligase (GCL) and glutathione synthetase, and GSSG depletion by Multidrug Resistance Protein 1 [320].

On the other hand, studies using zebrafish as a model organism, aimed to evaluate the toxicity of F-53B, are slightly more abundant. In larvae, the exposure to F-53B resulted again in a dose dependent decrease of GSH content [312,318]. Instead, the data relating to adult organisms show a differential response between sexes, with females presenting no significant difference in GSH content in liver of treated specimens compared to the controls [317].

Regarding the activity of antioxidant enzymes, the most analyzed proteins are SOD, CAT, and GPx. Exposure to PFAS leads to a generalized increase in SOD induction, which is reflected in an increased enzymatic activity. This occurs both in zebrafish treated with PFOS [307-309] and in non-model species used in laboratory treatments such as freshwater tilapia exposed to PFOA [184], or living in a PFAS polluted environment such as yellow perch (Perca flavescens) sampled from St. Lawrence River [321]. However, there are some exceptions, such as those highlighted with Japanese medaka (Oryzias latipes) and goldfish, in which exposure to PFOA did not change or decreased the SOD activity, respectively [306,322]. 
A non-unique effect is also produced by alternatives to PFOS. F-53B significantly decreased the SOD activity in zebrafish larvae and adults $[312,317,318]$, and 6:2 FTAB did not produce variations in treated zebrafish embryos [311].

All these data refer to the activity of $\mathrm{Cu}, \mathrm{ZnSOD}$, while for mitochondrial SOD (SOD2) the only available data have been found in chicken, where the activity of this enzyme increased after the treatments with PFOS or F-53B [319].

SOD induction is probably related to an increase in the formation rate of superoxide radicals, that are the specific target of this enzyme, whereas a decrease in cellular or tissue activity (for SOD as well as other antioxidant enzymes) is indicative of a more or less strong oxidative stress condition, in which an inactivation of the antioxidant defenses begins to occur [323].

CAT activity showed even greater variability than SOD one, with responses that are not only species-specific but also dose dependent. For example, in environmental conditions, where relatively low concentrations of PFAS are usually found, there was an increase in CAT activity, as in the case of yellow perch [321]. Exposure to higher concentrations under laboratory conditions may lead to an increase of CAT activity, as in zebrafish embryos exposed to $0.2,0.4$, and $1.0 \mathrm{mg} \mathrm{L}^{-1}$ PFOS [307], but a further slight increase $\left(1.6 \mathrm{mg} \mathrm{L}^{-1}\right)$ can be sufficient to exert inhibitory effects characteristic of oxidative stress [308]. Other fish species, such as freshwater tilapia, seems to be more resistant to oxidative stress, with CAT activities that continue to increase even in specimens exposed to $30 \mathrm{mg} \mathrm{L}^{-1}$ of PFOS or PFOA [184]. However, very high PFAS concentrations lead to a sharp decrease in enzymatic activity, as observed in zebrafish and Japanese medaka specimens exposed to PFOA [281,322].

The route of acquisition of these pollutants could also influence the variations in CAT activity, and in particular the food route does not seem to be useful to favor oxidative stress, as highlighted in rainbow trout (Oncorhynchus mykiss) fed with a PFOA enriched diet [324].

Even in the case of CAT, there are different effects between F-53B and 6:2 FTAB. The first significantly decreases the CAT activity in zebrafish larvae and adults $[312,317,318]$, the second produces incremental variations in treated zebrafish embryos [311]. In chicken, CAT activity was not significantly affected by the treatments with F-53B [319].

A similar variability was also observed for GPx. In some cases, exposure to PFAS did not produce any change in enzymatic activity, as in Japanese medaka after treatment with PFOA [322], in Arctic kittiwakes (Rissa sp.) that accumulate PFAS from the environment [325], or in chicken experimentally exposed to PFOS [319].

In other cases, an increase in GPx activity was observed, such as in zebrafish exposed to PFOS [307-309]. Instead, in freshwater tilapia was observed a dose dependent reduction of GPx activity after both PFOS and PFOA exposure [184].

Again, alternatives to PFOS produce variable effects, with F-53B that significantly induce GPx in zebrafish larvae and adults $[312,317,318]$, and 6:2 FTAB that instead decreases the GPx activity in treated zebrafish embryos [311].

It is interesting to note that often the enzymatic activities of CAT and GPx are inversely correlated. This has a physiological significance, as both enzymes target $\mathrm{H}_{2} \mathrm{O}_{2}$, and therefore they can play a complementary role within the antioxidant system, ensuring adequate protection of the cell against the negative effects of inorganic and organic peroxides [326].

In the literature there are no data on the activity of Prdxs, which are enzymes that have only recently received great attention from the scientific community and are therefore still poorly studied. Instead, there are some data, even if very limited, on the GR. In freshwater tilapia, GR activity significantly increased after exposure to PFOS or PFOA [184]. In chicken, GR activity were not significantly affected by the treatments with PFOS or F-53B [319], as well as GCL. This enzyme is not directly part of the antioxidant system but plays an essential role in the detoxification of ROS as it catalyzes the biosynthesis of GSH [327]. 


\subsection{Biomolecular Data}

The biomolecular data concern the expression of mRNA, analyzed by microarray or quantitative Real Time PCR. Generally, a transcription up-regulation of various genes encoding antioxidant enzymes was observed. In Juvenile Atlantic salmon (Salmo salar) sod, cat, and gpx genes were significantly up-regulated in kidney and liver upon exposure to PFOA or PFOS [328]. In rare minnow (Gobiocypris rarus) an up-regulation of $g p x 1$, prdx, and $m s r$ in specimens exposed to PFOA was reported $[329,330]$. In zebrafish $g p x 1$ and $p r d x 1$ gene transcriptions were significantly up-regulated in larvae and embryos under PFAS treatment [314,331]. In yellow perch an over-transcription of cat gene was observed in specimens from a PFAS polluted environment [321]. In largemouth bass (Micropterus salmoides) living in a PFOS polluted environment was observed an activation of gpx1a in testis and gpx4a in liver [332]. PFOS also triggered a mild increase in sod2 expression in chicken [319].

The activation of all these genes is probably related to a gene regulation that involves some enhancer sequences (antioxidant response elements, ARE) that are present in the gene promoters. This hypothesis is supported by the concomitant increase in mRNA expression of the gene that encodes the Nrf2 protein, the transcription factor that interacts with the ARE sequences, initiating gene transcription. The Nrf2 gene expression was significantly upregulated in liver of dark-spotted frog (Pelophylaxnigro maculatus) in response to PFOA [310], in zebrafish embryos upon exposure to PFOS [307], but also in larvae of this species exposed to F-53B [312].

However, the literature also reports other cases in which exposure to PFAS did not lead to an increase in the mRNA expression of the genes encoding antioxidant enzymes. For example, PFAS or F-53B exposure did not significantly affect the transcript levels of sod1 in zebrafish larvae [312,331]. This is evidently an indication that under those experimental conditions there was no consistent implementation of ROS formation rate. A similar situation, but involving other antioxidant enzyme genes (cat, gpx4, gr, and $g c l$ ), was found in chicken, where the exposure to a low dose of PFOS or a high dose of F-53B did not significantly affect the mRNA expression [319].

Finally, there are still other cases in which there was even a decrease in gene expression. This occurred in zebrafish, where exposure to PFAS significantly altered the gene transcription of sod1, cat, gpx1a, and prdx6 [281,308], in rare minnow, where gpx expression diminished in liver under treatment with PFOA [330], and in largemouth bass living in a PFOS polluted environment, where an inhibition of sod2, cat, $p r d x 1, \operatorname{prd} x 3$, and $\operatorname{prd} x 4$ was observed in various organs [332]. These inhibitions may be the result of a negative feedback control of gene expression but also of a toxic effect that can affect the activity of Nrf2.

These data, in addition to hint out a complex regulatory system that differentially involves the various antioxidant enzymes, highlight a feature of gene expression regulation already found for other antistress proteins. In fact, in many cases there was no correlation between the variation of active protein biosynthesis and the increase of mRNA expression. This may certainly be due to the different half-lives of these two types of molecules, but it is also known that mRNAs of stress proteins can be stored in cytoplasmic foci, such as P bodies or stress granules (SG), where they undergo degradation or future translation, respectively $[333,334]$. This condition is a common trait in organisms adapted to have a rapid response to the presence of a new stressor [335-337].

Table 2. PFAS effects on human and other vertebrates.

\begin{tabular}{|c|c|c|c|}
\hline Species & PFAS & Effects & References \\
\hline Carassius auratus & PFOA & $\begin{array}{l}\text { Increased ROS formation }{ }^{1} \text {, lipid peroxidation }{ }^{2}, \\
\text { GSH decrease }{ }^{3} \text {, SOD induction }{ }^{4} \text {, CAT induction }{ }^{4} \text {, } \\
\text { GPX inhibition }{ }^{4} \text {, GR induction }{ }^{4}\end{array}$ & [184] \\
\hline Danio rerio & PFOA & $\begin{array}{c}\text { CAT inhibition }{ }^{7} \text {, cat down-regulation }{ }^{8} \\
\operatorname{prdx} \text {, down-regulation }{ }^{8}\end{array}$ & [281] \\
\hline
\end{tabular}


Table 2. Cont.

\begin{tabular}{|c|c|c|c|}
\hline Species & PFAS & Effects & References \\
\hline Danio rerio & PFOS & $\begin{array}{l}\text { Increased ROS formation }{ }^{1} \text {, lipid peroxidation }{ }^{2} \text {, } \\
\text { SOD induction }{ }^{4} \text {, CAT induction }{ }^{4}, \\
\text { GPX induction }{ }^{4}, n r f 2 \text { up-regulation }{ }^{5}\end{array}$ & [307] \\
\hline Danio rerio & PFOS & $\begin{array}{l}\text { Increased ROS formation }{ }^{1} \text {, lipid peroxidation }{ }^{2} \text {, } \\
\text { SOD induction }{ }^{4} \text {, CAT inhibition }{ }^{4}, \\
\text { GPX induction }{ }^{4} \text {, sod down-regulation }{ }^{5} \\
\text { cat down-regulation }{ }^{5}, \text { gpx down-regulation }{ }^{5}\end{array}$ & [308] \\
\hline Danio rerio & PFOS & $\begin{array}{l}\text { Increased ROS formation }{ }^{1}, \text { SOD induction }{ }^{4} \\
\text { GPX induction }\end{array}$ & [309] \\
\hline Danio rerio & PFNA & Increased ROS formation ${ }^{1}$ & [310] \\
\hline Danio rerio & PFOA, PFNA & $\begin{array}{l}\text { Lipid peroxidation }{ }^{6}, g p x \text { up-regulation }{ }^{4} \\
\qquad r d x \text { up-regulation }{ }^{5}\end{array}$ & [314] \\
\hline Danio rerio & PFPiAs & $\begin{array}{c}\text { gpx up-regulation }{ }^{5}, p r d x \text { up-regulation }{ }^{5} \text {, } \\
m s r \text { up-regulation }{ }^{5}\end{array}$ & [331] \\
\hline $\begin{array}{l}\text { Gallus gallus } \\
\text { domesticus }\end{array}$ & PFOS & SOD induction ${ }^{4}$ & [319] \\
\hline Gobiocypris rarus & PFOA & $\begin{array}{c}g p x \text { down-regulation }{ }^{5}, p r d x \text { up-regulation }{ }^{5}, \\
m s r \text { up-regulation }{ }^{5}\end{array}$ & [329] \\
\hline Gobiocypris rarus & PFOA & $g p x$ up-regulation ${ }^{5}$ & [330] \\
\hline Homo sapiens & PFOA, PFOS & $\begin{array}{l}\text { Increased ROS formation }{ }^{1} \text {, apoptosis }{ }^{11} \\
\text { SOD induction }{ }^{4}, \text { CAT induction }{ }^{4} \\
\text { GR induction }{ }^{4}, \text { GPX inhibition }{ }^{4}\end{array}$ & [192] \\
\hline Homo sapiens & $\begin{array}{l}\text { PFHxS, PFOA, } \\
\text { PFOS, PFNA, } \\
\text { PFDA, PFUnA, } \\
\text { PFDoA }\end{array}$ & $\begin{array}{l}\text { Increased ROS formation }{ }^{1} \text {, increased DNA } \\
\text { damage }{ }^{9} \text {, antioxidant defense inhibition } 10\end{array}$ & [196] \\
\hline Homo sapiens & PFOA, PFOS & Estrogenicity and anti-estrogenicity 12 & [202] \\
\hline Homo sapiens & $\begin{array}{l}\text { PFOA, PFOS, } \\
\text { PFNA }\end{array}$ & $\begin{array}{l}\text { Estradiol production }{ }^{13}, \text { progesterone }{ }^{13} \\
\text { production, testosterone production }{ }^{13}\end{array}$ & [203] \\
\hline Homo sapiens & PFOA, PFOS & Thyroid diseases & [213] \\
\hline Homo sapiens & PFOA, PFOS & Chronic kidney diseases & [216] \\
\hline Homo sapiens & $\begin{array}{l}\text { PFHxS, PFOA, } \\
\text { PFOS, PFNA }\end{array}$ & Decreased eGFR ${ }^{14}$ & [217] \\
\hline Homo sapiens & $\begin{array}{l}\text { PFHxs, PFOA, } \\
\text { PFOS }\end{array}$ & Increased cholesterol outcomes 15 & [218] \\
\hline Homo sapiens & $\begin{array}{l}\text { PFOA, PFOS, } \\
\text { PFNA }\end{array}$ & $\begin{array}{l}\text { Hyperglycemia }{ }^{16} \text {, increased serum HDL } \\
\text { cholesterol }{ }^{16} \text {, increased blood insulin }{ }^{17}\end{array}$ & [219] \\
\hline Homo sapiens & PFOA, PFOS & $\begin{array}{l}\text { Increased blood levels of glucocorticoid }{ }^{17} \\
\text { increased blood levels of androgenic hormones }\end{array}$ & [222] \\
\hline Homo sapiens & PFOA, PFOS & $\begin{array}{l}\text { Increased total adiponectin levels }{ }^{19}, \\
\text { body weight decrease }\end{array}$ & [223] \\
\hline Homo sapiens & $\begin{array}{c}\text { PFHxS, PFHxA, } \\
\text { PFHpA, PFOA, } \\
\text { PFOS, PFNA, } \\
\text { PFDA, } \\
\text { PFUnDA, } \\
\text { PFDoDA, } \\
\text { PFTrDA, } \\
\text { PFTeDA }\end{array}$ & Allergic diseases & [224] \\
\hline
\end{tabular}


Table 2. Cont.

\begin{tabular}{|c|c|c|c|}
\hline Species & PFAS & Effects & References \\
\hline Homo sapiens & PFOA, PFOS & $\begin{array}{l}\text { Polyunsuturated fatty acids levels decrease }{ }^{20} \\
\text { birth weight decrease }\end{array}$ & [225] \\
\hline Homo sapiens & PFOA & Up-regulation of progesterone activated genes ${ }^{5}$ & [242] \\
\hline Homo sapiens & PFOA, PFOS & Increased T4 levels ${ }^{21}$ & [260] \\
\hline Homo sapiens & PFOA & Reduced fetal growth & [261] \\
\hline Homo sapiens & PFOA, PFOS & Reduced birth weight & [262] \\
\hline Homo sapiens & PFOA, PFOS & $\begin{array}{l}\text { Reduced cord serum concentrations and } \\
\text { birth weight size }\end{array}$ & [265] \\
\hline Homo sapiens & PFOA, PFOS & Affected growth of organs and the skeleton & [267] \\
\hline Homo sapiens & $\begin{array}{c}\text { PFBS, PFHxA, } \\
\text { PFHpA, PFHxS, } \\
\text { PFOA, PFOS, } \\
\text { PFNA, PFDA, } \\
\text { PFTA, PFDoA }\end{array}$ & Asthma & [268] \\
\hline Homo sapiens & $\begin{array}{l}\text { PFHxS, PFOA, } \\
\text { PFOS, PFNA }\end{array}$ & Asthma & [270] \\
\hline Homo sapiens & PFOA, PFOS & High insulin and trygliceride concentrations & [272] \\
\hline Homo sapiens & $\begin{array}{c}\text { PFOA, PFOS, } \\
\text { PFDeA }\end{array}$ & $\begin{array}{l}\text { Changes in lipid profile }{ }^{16}, \\
\text { changes in ALT levels }{ }^{16}\end{array}$ & [274] \\
\hline Homo sapiens & $\begin{array}{c}\text { PFOA, PFOS, } \\
\text { PFNA, PFHxS, } \\
\text { PFDeA, PFOSA, } \\
\text { Et-PFOSA, } \\
\text { Me-PFOSA }\end{array}$ & Increased $\mathrm{TSH}^{22}$, increased eGFR ${ }^{14}$ & [278] \\
\hline Homo sapiens & PFOA, PFOS & Reduced birth weight & [284] \\
\hline Homo sapiens & PFOA, PFOS & Increased cholesterol outcomes 16 & [287] \\
\hline Homo sapiens & $\begin{array}{l}\text { PFOA, PFOS, } \\
\text { PFNA, PFHxS }\end{array}$ & High serum cholesterol ${ }^{16}$ & [290] \\
\hline Homo sapiens & $\begin{array}{l}\text { PFOA, PFOS, } \\
\text { PFNA, PFHxS }\end{array}$ & High serum cholesterol ${ }^{16}$ & [291] \\
\hline Homo sapiens & PFOA & HNF $4 \alpha$ inhibition ${ }^{23}, h n f 4 \alpha$ down-regulation ${ }^{5}$ & [296] \\
\hline Homo sapiens & $\begin{array}{c}\text { PFOS, PFOA, } \\
\text { PFHxS, PFNA, } \\
\text { PFDA }\end{array}$ & Potential diabetogenic effect & [300] \\
\hline Homo sapiens & PFOA, PFOS & Potential adiposity, decreased beta-cell function & {$[301]$} \\
\hline Homo sapiens & PFOA & $\begin{array}{c}\text { Impaired platelet aggregation and increased } \\
\text { cardiovascular risk }\end{array}$ & [305] \\
\hline $\begin{array}{l}\text { Homo sapiens, } \\
\text { Mus musculus }\end{array}$ & $\begin{array}{l}\text { PFPA, PFHpA, } \\
\text { PFOA, PFUnA, } \\
\text { PFDoA }\end{array}$ & Increased PPAR $\alpha$ activity 24 & [65] \\
\hline $\begin{array}{l}\text { Homo sapiens, } \\
\text { Mus musculus }\end{array}$ & $\begin{array}{c}\text { PFOA, PFOS, } \\
\text { PFHxS, PFHxA, } \\
\text { PFNA, PFDA, } \\
\text { PFBA, PFBS }\end{array}$ & Increased PPAR $\alpha$ activity ${ }^{24}$ & [280] \\
\hline $\begin{array}{l}\text { Homo sapiens, } \\
\text { Mus musculus, } \\
\text { Rattus norvegicus }\end{array}$ & PFOA, PFOS & $\begin{array}{l}\text { Increased PPAR } \alpha \text { activity }{ }^{24} \text {, increased PPAR } \beta \\
\text { activity }{ }^{24} \text {, increased PPAR } \gamma \text { activity } 24\end{array}$ & [211] \\
\hline
\end{tabular}


Table 2. Cont.

\begin{tabular}{|c|c|c|c|}
\hline Species & PFAS & Effects & References \\
\hline $\begin{array}{l}\text { Homo sapiens, } \\
\text { Mus musculus, } \\
\text { Rattus norvegicus }\end{array}$ & PFOA, PFOS & Reduced birth weight & [266] \\
\hline $\begin{array}{l}\text { Homo sapiens, } \\
\text { Rattus norvegicus }\end{array}$ & PFOA, PFOS & $\begin{array}{l}\text { Up-regulation of multiple nuclear } \\
\text { receptor genes } 5\end{array}$ & [285] \\
\hline $\begin{array}{l}\text { Micropterus } \\
\text { salmoides }\end{array}$ & PFOS & $\begin{array}{l}\text { gpx up-regulation }{ }^{8}, \text { sod down-regulation }{ }^{8} \text {, cat } \\
\text { up-regulation }{ }^{8}, p r d x \text { down-regulation }{ }^{8}\end{array}$ & [332] \\
\hline Mus musculus & PFOA & $\begin{array}{c}\text { Lipid peroxidation }{ }^{25} \text {, amylase induction, lipase } \\
\text { induction, sod1 up-regulation }{ }^{5} \\
\text { sod2 up-regulation } 5, \text { gp } x 2 \text { up-regulation }{ }^{5} \\
\text { nqo1 up-regulation }{ }^{5}\end{array}$ & [204] \\
\hline Mus musculus & PFOS & $\begin{array}{l}\text { Increased in peroxisomal fatty acid beta-oxidation } \\
4, \text { increased peroxisomal catalase activity }{ }^{4}\end{array}$ & [208] \\
\hline Mus musculus & PFOA & ppar $\alpha$ up-regulation ${ }^{5}$, ppary up-regulation ${ }^{5}$ & [209] \\
\hline Mus musculus & PFOS & $\begin{array}{l}\text { Serum testosterone decrease }{ }^{19} \text {, epididymal sperm } \\
\text { counts decrease, down-regulation of genes } \\
\text { encoding testicular receptors for gonadotropin, } \\
\text { growth hormone, insulin-like growth factor } 1 \text { and } \\
\text { steroidogenic enzymes }{ }^{5}\end{array}$ & [234] \\
\hline Mus musculus & PFOA & $\begin{array}{l}\text { Damaged seminiferous tubules, reduced sperm } \\
\text { quality, reduced serum testosterone and } \\
\text { progesterone levels }{ }^{13} \text {, INSL3 enzyme decrease }{ }^{23} \text {, } \\
\text { cytochrome P450 decrease } 23\end{array}$ & [235] \\
\hline Mus musculus & PFOS & Immune response induction ${ }^{19}$ & [269] \\
\hline $\begin{array}{l}\text { Oncorhynchus } \\
\text { mykiss }\end{array}$ & PFOA & CAT inhibition ${ }^{4}$ & [324] \\
\hline $\begin{array}{l}\text { Oreochromis } \\
\text { niloticus }\end{array}$ & PFOA, PFOS & $\begin{array}{l}\text { Increased ROS formation }{ }^{1} \text {, lipid peroxidation }{ }^{2} \text {, } \\
\text { GSH decrease }\end{array}$ & [306] \\
\hline Oryzias latipes & PFOA & SOD inhibition ${ }^{4}$, CAT inhibition ${ }^{4}$ & [322] \\
\hline $\begin{array}{l}\text { Pelophylaxnigro } \\
\text { maculatus }\end{array}$ & PFOA & $n r f 2$ up-regulation ${ }^{5}$ & [313] \\
\hline Perca flavescens & $\begin{array}{l}\text { PFHxS, PFOS, } \\
\text { PFDS, PFECHS, } \\
\text { PFOA, PFNA, } \\
\text { PFDA, PFUnA, } \\
\text { PFDoA, PFTriA, } \\
\text { PFTetraA }\end{array}$ & $\begin{array}{c}\text { SOD induction }{ }^{4}, \text { CAT induction } \\
\text { down-regulation }\end{array}$ & [321] \\
\hline $\begin{array}{l}\text { Pimephales } \\
\text { promelas }\end{array}$ & PFOA, PFOS & Lipid peroxidation 6 & [315] \\
\hline Rattus norvegicus & PFOA & $\begin{array}{l}\text { Increased ROS formation }{ }^{1} \text {, increased } \\
\text { mithocondrial superoxide formation }{ }^{25} \text {, increased } \\
\text { nitric oxide formation }{ }^{1} \text {, apoptosis }{ }^{19} \text {, increased } \\
\text { proinflammatory cytokines }{ }^{19} \text {, reduced adenosine } \\
\text { triphosphate levels }{ }^{26} \text {, reduced cardiolipin } \\
\text { peroxidation }{ }^{27} \text {, reduced cytochrome c release }\end{array}$ & [200] \\
\hline Rattus norvegicus & PFOA & $\begin{array}{c}\text { Increased ACO activity }{ }^{4}, \\
\text { increased PPAR } \alpha \text { activity }\end{array}$ & [207] \\
\hline Rattus norvegicus & PFDoA & $\begin{array}{l}\text { Serum testosterone decrease }{ }^{19}, \text { serum estradiol } \\
\text { decrease }{ }^{19}, \text { down-regulation of genes involved in } \\
\text { cholesterol transport and steroid biosynthesis }{ }^{5}\end{array}$ & [233] \\
\hline
\end{tabular}


Table 2. Cont.

\begin{tabular}{|c|c|c|c|}
\hline Species & PFAS & Effects & References \\
\hline Rattus norvegicus & PFOA & $\begin{array}{l}\text { Up-regulation of genes involved in metabolism of } \\
\text { lipids, cell communication, growth, hormone } \\
\text { regulatory pathways, proteolysis, peptidolysis and } \\
\text { signal transduction } 8 \text {, down-regulation of genes } \\
\text { involved in inflammation and immunity, } \\
\text { regulation of hormones, general metabolism and } \\
\text { G-protein coupled receptor protein signaling } \\
\text { pathways }{ }^{8}\end{array}$ & [294] \\
\hline Salmo salar & PFOA, PFOS & $\begin{array}{c}\text { sod up-regulation }{ }^{5} \text {, cat up-regulation }{ }^{5} \\
g p x \text { up-regulation }\end{array}$ & [328] \\
\hline Ursus marittimus & PFASs & Increased levels of brain steroid hormones 28 & [295] \\
\hline \multicolumn{4}{|c|}{$\begin{array}{l}{ }^{1} 2^{\prime}, 7^{\prime} \text {-dichlorofluorescein deacetate; }{ }^{2} \text { malondialdehyde; }{ }^{3} \text { 4-chloro-1-methyl-7-trifluoromethylquinolinium } \\
\text { methylsulfate; }{ }^{4} \text { enzymatic activity; }{ }^{5} \text { quantitative real-time PCR; }{ }^{6} \text { thiobarbituric acid reactive species; }{ }^{7} \\
\text { MALDI-TOF-TOF mass spectrometry; }{ }^{8} \text { microarray; }{ }^{9} \text { comet assay; }{ }^{10} \text { total antioxidant capacity; }{ }^{11} \text { FACSort flow } \\
\text { cytometry; }{ }^{12} \text { E-SCREEN bioassay; }{ }^{13} \text { Coat-a-count radioimmunoassay; }{ }^{14} \text { serum creatinine; }{ }^{15} \text { Ortho VITROS Clinical } \\
\text { Analyzer; }{ }^{16} \text { enzymatic assay; }{ }^{17} \text { immunoenzymometric assay; }{ }^{18} \text { liquid chromatography-tandem mass spectrometry; } \\
{ }^{19} \text { Enzyme Linked ImmunoSorbent Assay; }{ }^{20} \text { gas chromatography-mass spectrometry; }{ }^{21} \text { AutoDELFIA fully } \\
\text { automated system; }{ }^{22} \text { isometric assay; }{ }^{23} \text { Wester blotting; }{ }^{24} \text { transactivation assay; }{ }^{25} \text { MitoSOX }{ }^{\mathrm{TM}} \text { Red mitochondrial } \\
\text { superoxide indicator; }{ }^{26} \text { ATP colorimetric assay; } ;{ }^{27} 10-\mathrm{N} \text {-nonyl-Acridine Orange; }{ }^{28} \text { mass spectrometry. }\end{array}$} \\
\hline
\end{tabular}

\section{Conclusions}

Although many PFAS are no longer used in industrial activities, these chemicals are expected to pose a serious threat to humans and the environment in which they live for many years to come, because of their bioaccumulative properties and environmental persistence. In parallel, the production and use of replacement chemicals, some of which may already have been under production for decades, has been on the rise [338]. Among these, the F-53B component 6:2 chlorinated polyfluoroalkyl ether sulfonate (6:2 Cl-PFESA) has attracted attention since 2013 when the first report on its persistence, toxicity, and environmental occurrence was published [339]. Hexafluoropropylene oxide dimer acid (HFPO-DA; Gen-X) and dodecafluoro-3H-4,8-dioxanonanoate (ADONA) have also been the subject of several monitoring surveys of surface water and drinking water [340]. However, limited data are available regarding the environmental fate and ecotoxicology of such alternatives [338,341].

The available literature on PFAS shows that this group of chemicals causes a wide range of adverse outcomes in humans, most of which are related to oxidative stress, but there are still significant gaps in the current knowledge on the toxicity of these compounds. In particular, the knowledge on mechanisms by which PFAS act in generating cell toxicity is still very limited, starting from the role that is played by PPARs in the activation of cellular signaling when they bind and are activated by PFAS [342]. Therefore, future studies should focus on these gaps, in order to better counteract the negative consequences of PFAS on people exposed to these pollutants, but also on ecosystems, whose health and biodiversity of species is not at all unrelated to survival of the human species.

Author Contributions: Conceptualization, M.B. (Marco Bonato), F.C. and L.T.; Writing-Original draft preparation, M.B. (Marco Bonato), F.C., L.T., P.I., and G.S.; writing-Review and editing, M.B. (Marta Bellio), L.G., P.I. and G.S.; supervision, G.S. All authors have read and agreed to the published version of the manuscript.

Funding: This research received no external funding.

Conflicts of Interest: The authors declare no conflict of interest.

\section{Abbreviations}

acyl CoA oxidase 
Bisphenol A BPA

Catalase CAT

Cyclooxygenase 2

Dichlorodiphenyldichloroethylene

COX-2

Endocrine Disruptors

DDE

Glutamyl-Cysteine Ligase

ED

Glomerular Filtration Rate

GCL

GFR

$\gamma$-glutamyl transferase

GGT

Glutathione peroxidase $\quad$ GPx

Glutathione Reductase GR

Glutathione S-transferase GST

Hepatocyte nuclear factor 4 alpha $\quad H N F 4 \alpha$

Health Protection Agency HPA

insulin like factor $3 \quad$ INSL3

Luteinizing Hormone LH

Methionine sulfoxide reductases $\quad$ Msr

Normal Granulosa Cells $\quad$ N-GCs

National Health and Nutrition Examination Survey NHANES

Nurses' Health Study II NHSII

Nitric Oxide NO

Polychlorinated Biphenyls $\quad$ PCBs

Granulosa Cells from Polycystic Ovaries PCO-GCs

Perfluorinated Alkyl Substances PFAS

Perfluorinated Carboxylic Acids PFCA

Perfluorinated compounds PFCs

Perfluorobutanoic acid PFBA

Perfluorobutane sulfonate PFBS

Perfluorodecanoic acid PFDA

Perfluorododecanoic acid PFDoA

Perfluoroheptanoic acid PFHpA

Perfluorohexanoic acid PFHxA

Perfluorohexanesulfonic acid PFHxS

Perfluorononanoic acid PFNA

Perfluorooctanoic acid PFOA

Perfluorooctane sulfonic acid PFOS

Perfluoropentanoic acid PFPeA

Perfluoroalkyl phosphinic acid PFPiAs

Perfluoroundecanoic acid PFUnA

Persistent Mobile Organic Contaminants PMOC

Peroxisome Proliferator-Activated Receptor PPAR

Peroxiredoxins Prdx

Reactive Oxygen Species ROS

Stress Granules $\quad$ SG

Superoxide Dismutase SOD

Type 2 Diabetes T2D

Thyroxine $\quad \mathrm{T} 4$

Total Antioxidant Capacity $\quad$ TAC

Total Cholesterol TC

Tolerable Daily Intake $\quad$ TDI

$\begin{array}{ll}\text { Triglycerides } & \text { TG }\end{array}$ 


\section{References}

1. Schieber, M.; Chandel, N.S. ROS function in redox signaling and oxidative stress. Curr. Biol. 2014, 24, R453-R462. [CrossRef] [PubMed]

2. Acworth, I.N.; McCabe, D.R.; Maher, T.J. The Analysis of Free Radicals, Their Reaction Products, and Antioxidants. In Oxidants, Antioxidants, and Free Radicals; Baskin, S.I., Salem, H., Eds.; Taylor Francis: Washington, DC, USA, 1997; pp. 23-77.

3. Valko, M.; Leibfritz, D.; Moncol, J.; Cronin, M.T.D.; Mazur, M.; Telser, J. Free radicals and antioxidants in normal physiological functions and human disease. Int. J. Biochem. Cell Biol. 2007, 39, 44-84. [CrossRef] [PubMed]

4. Wang, J.; Yi, J. Cancer cell killing via ROS: To increase or decrease, that is a question. Cancer Biol. Ther. 2008, 7, 1875-1884. [CrossRef] [PubMed]

5. Lodovici, M.; Bigagli, E. Oxidative stress and air pollution exposure. J. Toxicol. 2011, 2011, 487074. [CrossRef] [PubMed]

6. Federico, A.; Cardaioli, E.; Da Pozzo, P.; Formichi, P.; Gallus, G.N.; Radi, E. Mitochondria, oxidative stress and neurodegeneration. J. Neurol. Sci. 2012, 322, 254-262. [CrossRef]

7. Zahn, D.; Neuwald, I.J.; Knepper, T.P. Analysis of mobile chemicals in the aquatic environment-current capabilities, limitations and future perspectives. Anal. Bioanal. Chem. 2020, 412, 4763-4784. [CrossRef] [PubMed]

8. Gorbi, S.; Virno Lamberti, C.; Notti, A.; Benedetti, M.; Fattorini, D.; Moltedo, G.; Regoli, F. An ecotoxicological protocol with caged mussels, Mytilus galloprovincialis, for monitoring the impact of an offshore platform in the Adriatic Sea. Mar. Environ. Res. 2008, 65, 34-49. [CrossRef]

9. Valko, M.; Jomova, K.; Rhodes, C.J.; Kuča, K.; Musílek, K. Redox- and non-redox-metal-induced formation of free radicals and their role in human disease. Arch. Toxicol. 2016, 90, 1-37. [CrossRef]

10. Halliwell, B. Antioxidant defence mechanisms: From the beginning to the end (of the beginning). Free Radic. Res. 1999, 31, 261-272. [CrossRef]

11. Ferro, K.; Ferro, D.; Corrà, F.; Bakiu, R.; Santovito, G.; Kurtz, J. Cu, Zn superoxide dismutase genes in Tribolium castaneum: Evolution, molecular characterisation, and gene expression during immune priming. Front. Immunol. 2017, 8. [CrossRef]

12. Chatzidimitriou, E.; Bisaccia, P.; Corrà, F.; Bonato, M.; Irato, P.; Manuto, L.; Toppo, S.; Bakiu, R.; Santovito, G. Copper/zinc superoxide dismutase from the crocodile icefish Chionodraco hamatus: Antioxidant defense at constant sub-zero temperature. Antioxidants 2020, 9, 325. [CrossRef] [PubMed]

13. Muhtadi, R.; Lorenz, A.; Mpaulo, S.J.; Siebenwirth, C.; Scherthan, H. Catalase T-deficient fission yeast meiocytes show resistance to ionizing radiation. Antioxidants 2020, 9, 881. [CrossRef] [PubMed]

14. Ferro, D.; Franchi, N.; Bakiu, R.; Ballarin, L.; Santovito, G. Molecular characterization and metal induced gene expression of the novel glutathione peroxidase 7 from the chordate invertebrate Ciona Robusta. Comp. Biochem. Physiol. C 2018, 205, 1-7. [CrossRef] [PubMed]

15. Al-Asadi, S.; Malik, A.; Bakiu, R.; Santovito, G.; Schuller, K. Characterization of the peroxiredoxin 1 subfamily from Tetrahymena thermophila. Cell. Mol. Life Sci. 2019, 76, 4745-4768. [CrossRef] [PubMed]

16. Tolomeo, A.M.; Carraro, A.; Bakiu, R.; Toppo, S.; Garofalo, F.; Pellegrino, D.; Gerdol, M.; Ferro, D.; Place, S.P.; Santovito, G. Molecular characterization of novel mitochondrial peroxiredoxins from the Antarctic emerald rockcod and their gene expression in response to environmental warming. Comp. Biochem. Physiol. C 2019, 255, 108580. [CrossRef]

17. Ricci, F.; Lauro, F.M.; Grzymski, J.J.; Read, R.; Bakiu, R.; Santovito, G.; Luporini, P.; Vallesi, A. The anti-oxidant defense system of the marine polar ciliate Euplotes nobilii: Characterization of the msrB gene family. Biology 2017, 6, 4. [CrossRef]

18. Formigari, A.; Boldrin, F.; Santovito, G.; Cassidy-Hanley, D.; Clark, T.G.; Piccinni, E. Functional characterization of the $5^{\prime}$-upstream region of MTT5 metallothionein gene from Tetrahymena thermophila. Protist 2010, 161, 71-77. [CrossRef]

19. Santovito, G.; Boldrin, F.; Irato, P. Metal and metallothionein distribution in different tissues of the Mediterranean clam Venerupis philippinarum during copper treatment and detoxification. Comp. Biochem. Physiol. C 2015, 174-175, 46-53. [CrossRef] 
20. Jakubczyk, K.; Kałduńska, J.; Dec, K.; Kawczuga, D.; Janda, K. Antioxidant properties of small-molecule non-enzymatic compounds. Pol. Merkur. Lekarski 2020, 48, 128-132.

21. Haug, L. Approaches to integrating the toxicology and epidemiology evidence on PFAS. Environ. Epidemiol. 2019, 3, 210. [CrossRef]

22. Cousins, I.T.; DeWitt, J.C.; Glüge, J.; Goldenman, G.; Herzke, D.; Lohmann, R.; Miller, M.; Ng, C.A.; Scheringer, M.; Vierke, L.; et al. Strategies for grouping per- and polyfluoroalkyl substances (PFAS) to protect human and environmental health. Environ. Sci. Process Impacts 2020, 22, 1444-1460. [CrossRef]

23. Hansen, K.J.; Clemen, L.A.; Ellefson, M.; Johnson, H.O. Compound-specific, quantitative characterization of organic fluorochemicals in biological matrices. Environ. Sci. Technol. 2001, 35, 766-770. [CrossRef]

24. Remde, A.; Debus, R. Biodegradability of fluorinated surfactants under aerobic and anaerobic conditions. Chemosphere 1996, 32, 1563-1574. [CrossRef]

25. Schröder, H.F. Determination of fluorinated surfactants and their metabolites in sewage sludge samples by liquid chromatography with mass spectrometry and tandem mass spectrometry after pressurised liquid extraction and separation on fluorine-modified reversed-phase sorbents. J. Chromatogr. A 2003, 1020, 131-151. [CrossRef] [PubMed]

26. Sáez, M.; de Voogt, P.; Parsons, J.R. Persistence of perfluoroalkylated substances in closed bottle tests with municipal sewage sludge. Environ. Sci. Pollut. Res. Int. 2008, 15, 472-477. [CrossRef]

27. Frömel, T.; Knepper, T.P. Biodegradation of fluorinated alkyl substances. Rev. Environ. Contam. Toxicol. 2010, 208, 161-177. [CrossRef] [PubMed]

28. Buck, R.C.; Franklin, J.; Berger, U.; Conder, J.M.; Cousins, I.T.; de Voogt, P.; Jensen, A.A.; Kannan, K.; Mabury, S.A.; van Leeuwen, S.P. Perfluoroalkyl and polyfluoroalkyl substances in the environment: Terminology, classification, and origins. Integr. Environ. Assess. Manag. 2011, 7, 513-541. [CrossRef] [PubMed]

29. Lau, C.; Anitole, K.; Hodes, C.; Lai, D.; Pfahles-Hutchens, A.; Seed, J. Perfluoroalkyl acids: A review of monitoring and toxicological findings. Toxicol. Sci. 2007, 99, 366-394. [CrossRef] [PubMed]

30. Wang, Z.; DeWitt, J.C.; Higgins, C.P.; Cousins, I.T. A never-ending story of per- and polyfluoroalkyl substances (PFAS)? Environ. Sci. Technol. 2017, 51, 2508-2518. [CrossRef]

31. Ghisi, R.; Vamerali, T.; Manzetti, S. Accumulation of perfluorinated alkyl substances (PFAS) in agricultural plants: A review. Environ. Res. 2019, 169, 326-341. [CrossRef]

32. Bossi, R.; Riget, F.F.; Dietz, R.; Sonne, C.; Fauser, P.; Dam, M.; Vorkamp, K. Preliminary screening of perfluorooctane sulfonate (PFOS) and other fluorochemicals in fish, birds and marine mammals from Greenland and the Faroe Islands. Environ. Pollut. 2005, 136, 323-329. [CrossRef] [PubMed]

33. Cai, M.; Zhao, Z.; Yin, Z.; Ahrens, L.; Huang, P.; Cai, M.; Yang, H.; He, J.; Sturm, R.; Ebinghaus, R. Occurrence of perfluoroalkyl compounds in surface waters from the North Pacific to the Arctic Ocean. Environ. Sci. Technol. 2011, 44, 661-668. [CrossRef] [PubMed]

34. Holmström, K.E.; Järnberg, U.; Bignert, A. Temporal trends of PFOS and PFOA in guillemot eggs from the Baltic Sea, 1968-2003. Environ. Sci. Technol. 2005, 39, 80-84. [CrossRef]

35. Paul, A.G.; Jones, K.C.; Sweetman, A.J. A first global production, emission, and environmental inventory for perfluorooctane sulfonate. Environ. Sci. Technol. 2008, 43, 386-392. [CrossRef]

36. Zhao, Y.; Wong, C.; Wong, M. Environmental contamination, human exposure and body loadings of perfluorooctane sulfonate (PFOS), focusing on Asian countries. Chemosphere 2012, 89, 355-368. [CrossRef] [PubMed]

37. Bytingsvik, J.; Van Leeuwen, S.P.J.; Hamers, T.; Swart, K.; Aars, J.; Lie, E.; Nilsen, E.M.E.; Wiig, O.; Derocher, A.E.; Jenssen, B.M. Perfluoroalkyl substances in polar bear mother-cub pairs: A comparative study based on plasma levels from 1998 and 2008. Environ. Int. 2012, 49, 92-99. [CrossRef]

38. Muir, D.; Bossi, R.; Carlsson, P.; Evans, M.; De Silva, A.; Halsall, C.; Rauert, C.; Herzke, D.; Hung, H.; Letcher, R.; et al. Levels and trends of poly- and perfluoroalkyl substances in the Arctic environment-An update. Emerg. Contam. 2019, 5, 240-271. [CrossRef]

39. Ahrens, L.; Xie, Z.; Ebinghaus, R. Distribution of perfluoroalkyl compounds in seawater from Northern Europe, Atlantic Ocean, and Southern Ocean. Chemosphere 2010, 78, 1011-1016. [CrossRef] 
40. Herzke, D.; Huber, S.; Bervoets, L.; D’Hollander, W.; Hajslova, J.; Pulkrabova, J.; Brambilla, G.; De Filippis, S.P.; Klenow, S.; Heinemeyer, G. Perfluorinated alkylated substances in vegetables collected in four European countries; occurrence and human exposure estimations. Environ. Sci. Pollut. Res. 2013, 20, 7930-7939. [CrossRef]

41. Jin, Y.H.; Liu, W.; Sato, I.; Nakayama, S.F.; Sasaki, K.; Saito, N.; Tsuda, S. PFOS and PFOA in environmental and tap water in China. Chemosphere 2009, 77, 605-611. [CrossRef]

42. Kowalczyk, J.; Ehlers, S.; Oberhausen, A.; Tischer, M.; Fürst, P.; Schafft, H.; Lahrssen-Wiederholt, M. Absorption, distribution, and milk secretion of the perfluoroalkyl acids PFBS, PFHxS, PFOS, and PFOA by dairy cows fed naturally contaminated feed. J. Agric. Food Chem. 2013, 61, 2903-2912. [CrossRef] [PubMed]

43. Loos, R.; Gawlik, B.M.; Locoro, G.; Rimaviciute, E.; Contini, S.; Bidoglio, G. EU wide survey of polar organic persistent pollutants in European river waters. Environ. Pollut. 2009, 157, 561-568. [CrossRef] [PubMed]

44. So, M.; Taniyasu, S.; Yamashita, N.; Giesy, J.; Zheng, J.; Fang, Z.; Im, S.; Lam, P.K. Perfluorinated compounds in coastal waters of Hong Kong, South China, and Korea. Environ. Sci. Technol. 2004, 38, 4056-4063. [CrossRef]

45. So, M.; Miyake, Y.; Yeung, W.; Ho, Y.; Taniyasu, S.; Rostkowski, P.; Yamashita, N.; Zhou, B.; Shi, X.; Wang, J. Perfluorinated compounds in the Pearl river and Yangtze river of China. Chemosphere 2007, 68, 2085-2095. [CrossRef]

46. Washington, J.W.; Yoo, H.; Ellington, J.J.; Jenkins, T.M.; Libelo, E.L. Concentrations, distribution, and persistence of perfluoroalkylates in sludge-applied soils near Decatur, Alabama, USA. Environ. Sci. Technol. 2010, 44, 8390-8396. [CrossRef] [PubMed]

47. Arinaitwe, K.; Koch, A.; Taabu-Munyaho, A.; Marien, K.; Reemtsma, T.; Berger, U. Spatial profiles of perfluoroalkyl substances and mercury in fish from northern Lake Victoria, East Africa. Chemosphere 2020, 260, 127536. [CrossRef]

48. Banzhaf, S.; Filipovic, M.; Lewis, J.; Sparrenbom, C.J.; Barthel, R. A review of contamination of surface-, ground-, and drinking water in Sweden by perfluoroalkyl and polyfluoroalkyl substances (PFAS). Ambio 2017, 46, 335-346. [CrossRef]

49. Prevedouros, K.; Cousins, I.T.; Buck, R.C.; Korzeniowski, S.H. Sources, fate and transport of perfluorocarboxylates. Environ. Sci. Technol. 2006, 40, 32-44. [CrossRef]

50. Wang, Z.; Cousins, I.T.; Scheringer, M.; Buck, R.C.; Hungerbu“hler, K. Global emission inventories for C4-C14 perfluoroalkyl carboxylic acid (PFCA) homologues from 1951 to 2030, part I: Production and emissions from quantifiable sources. Environ. Int. 2014, 70, 62-75. [CrossRef]

51. Gredelj, A.; Nicoletto, C.; Valsecchi, S.; Ferrario, C.; Polesello, S.; Lava, R.; Zanon, F.; Barausse, A.; Palmeri, L.; Guidolin, L.; et al. Uptake and translocation of perfluoroalkyl acids (PFAA) in red chicory (Cichorium intybus L.) under various treatments with pre-contaminated soil and irrigation water. Sci. Total Environ. 2020, 708, 134766. [CrossRef]

52. Borg, D.; Lund, B.O.; Lindquist, N.G.; Håkansson, H. Cumulative health risk assessment of 17 perfluoroalkylated and polyfluoroalkylated substances (PFAS) in the Swedish population. Environ. Int. 2013, 59, 112-123. [CrossRef]

53. Ahrens, L. Polyfluoroalkyl compounds in the aquatic environment: A review of their occurrence and fate. J. Environ. Monit. 2011, 13, 20-31. [CrossRef] [PubMed]

54. Houde, M.; De Silva, A.O.; Muir, D.C.; Letcher, R.J. Monitoring of perfluorinated compounds in aquatic biota: An updated review. Environ. Sci. Technol. 2011, 45, 7962-7973. [CrossRef]

55. Kannan, K.; Koistinen, J.; Beckmen, K.; Evans, T.; Gorzelany, J.F.; Hansen, K.J.; Jones, P.D.; Helle, E.; Nyman, M.; Giesy, J.P. Accumulation of perfluorooctane sulfonate in marine mammals. Environ. Sci. Technol. 2011, 35, 1593-1598. [CrossRef]

56. Kannan, K.; Tao, L.; Sinclair, E.; Pastva, S.D.; Jude, D.J.; Giesy, J.P. Perfluorinated compounds in aquatic organisms at various trophic levels in a Great Lakes food chain. Arch. Environ. Contam. Toxicol. 2005, 48, 559-566. [CrossRef]

57. Yamashita, N.; Kannan, K.; Taniyasu, S.; Horii, Y.; Petrick, G.; Gamo, T. A global survey of perfluorinated acids in oceans. Mar. Pollut. Bull. 2005, 51, 658-668. [CrossRef]

58. Fujii, S.; Polprasert, C.; Tanaka, S.; Lien, N.P.; Qui, Y. New POPs in the water environment: Distribution, bioaccumulation and treatment of perfluorinated compounds: A review paper. J. Water Suppl. Res. Technol. AQUA 2007, 56, 313-326. [CrossRef] 
59. Arvaniti, O.S.; Stasinakis, A.S. Review on the occurrence, fate and removal of perfluorinated compounds during wastewater treatment. Sci. Total Environ. 2015, 524-525, 81-92. [CrossRef] [PubMed]

60. Filipovic, M.; Berger, U. Are perfluoroalkyl acids in waste water treatment plant effluents the result of primary emissions from the technosphere or of environmental recirculation? Chemosphere 2015, 129, 74-80. [CrossRef]

61. Upham, B.L.; Park, J.S.; Babica, P.; Sovadinova, I.; Rummel, A.M.; Trosko, J.E.; Hirose, A.; Hasegawa, R.; Kanno, J.; Sai, K. Structure-activity-dependent regulation of cell communication by perfluorinated fatty acids using in vivo and in vitro model systems. Environ. Health Perspect. 2009, 117, 545-551. [CrossRef]

62. Klaunig, J.E.; Shinohara, M.; Iwai, H.; Chengelis, C.P.; Kirkpatrick, J.B.; Wang, Z.; Bruner, R.H. Evaluation of the chronic toxicity and carcinogenicity of perfluorohexanoic acid (PFHxA) in Sprague-Dawley rats. Toxicol. Pathol. 2014, 43, 209-220. [CrossRef] [PubMed]

63. Rosen, M.B.; Das, K.P.; Wood, C.R.; Wolf, C.J.; Abbott, B.D.; Lau, C. Evaluation of perfluoroalkyl acid activity using primary mouse and human hepatocytes. Toxicology 2013, 308, 129-137. [CrossRef]

64. Vongphachan, V.; Cassone, C.G.; Wu, D.; Chiu, S.; Crump, D.; Kennedy, S.W. Effects of perfluoroalkyl compounds (PFAS) on mRNA expression levels of thyroid hormone-responsive genes in primary cultures of avian neuronal cells. Toxicol. Sci. 2011, 120, 392-402. [CrossRef] [PubMed]

65. Wolf, C.J.; Schmid, J.E.; Lau, C.; Abbott, B.D. Activation of mouse and human peroxisome proliferator-activated receptor-alpha (PPAR $\alpha$ ) by perfluoroalkyl acids (PFAAs): Further investigation of C4-C12 compounds. Reprod. Toxicol. 2012, 33, 546-551. [CrossRef]

66. Abbott, B.D.; Wolf, C.J.; Schmid, J.E.; Das, K.P.; Zehr, R.D.; Helfant, L.; Nakayama, S.; Lindstrom, A.B.; Strynar, M.J.; Lau, C. Perfluorooctanoic acid-induced developmental toxicity in the mouse is dependent on expression of peroxisome proliferator- activated receptor-alpha. Toxicol. Sci. 2007, 98, 571-581. [CrossRef]

67. Kudo, N.; Kawashima, Y. Toxicity and toxicokinetics of perfluorooctanoic acid in humans and animals. J. Toxicol. Sci. 2003, 28, 49-57. [CrossRef]

68. Wolf, C.J.; Fenton, S.E.; Schmid, J.E.; Calafat, A.M.; Kuklenyik, Z.; Bryant, X.A.; Thibodeaux, J.; Das, K.P.; White, S.S.; Lau, C.S. Developmental toxicity of perfluorooctanoic acid in the CD-1 mouse after cross-foster and restricted gestational exposures. Toxicol. Sci. 2007, 95, 462-473. [CrossRef]

69. Henderson, W.M.; Smith, M.A. Perfluorooctanoic acid and perfluorononanoic acid in fetal and neonatal mice following in utero exposure to 8-2 fluorotelomer alcohol. Toxicol. Sci. 2007, 95, 452-461. [CrossRef]

70. Fang, X.; Zhang, L.; Feng, Y.; Zhao, Y.; Dai, J. Immunotoxic effects of perfluorononanoic acid on BALB/c mice. Toxicol. Sci. 2008, 105, 312-321. [CrossRef] [PubMed]

71. Wolf, C.J.; Zehr, R.D.; Schmid, J.E.; Lau, C.; Abbott, B.D. Developmental effects of perfluorononanoic acid in the mouse are dependent on peroxisome proliferator-activated receptor-alpha. PPAR Res. 2010, 2010, 282896. [CrossRef] [PubMed]

72. Harris, M.W.; Birnbaum, L.S. Developmental toxicity of perfluorodecanoic acid in C57BL/6N mice. Toxicol. Sci. 1989, 12, 442-448. [CrossRef]

73. Heuvel, J.P.V.; Kuslikis, B.I.; Peterson, R.E. Covalent binding of perfluorinated fatty acids to proteins in the plasma, liver and testes of rats. Chem. Biol. Interact. 1992, 82, 317-328. [CrossRef]

74. Takahashi, M.; Ishida, S.; Hirata-Koizumi, M.; Ono, A.; Hirose, A. Repeated dose and reproductive/ developmental toxicity of perfluoroundecanoic acid in rats. J. Toxicol. Sci. 2014, 39, 97-108. [CrossRef]

75. Liu, H.; Zhang, H.; Cui, R.; Guo, X.; Wang, D.; Dai, J. Activation of peroxisome proliferator-activated receptor $\alpha$ ameliorates perfluorododecanoic acid-induced production of reactive oxygen species in rat liver. Arch. Toxicol. 2016, 90, 1383-1397. [CrossRef]

76. Ren, X.M.; Zhang, Y.F.; Guo, L.H.; Qin, Z.F.; Lv, Q.Y.; Zhang, L.Y. Structure-activity relations in binding of perfluoroalkyl compounds to human thyroid hormone T3 receptor. Arch. Toxicol. 2015, 89, 233-242. [CrossRef]

77. Zhang, H.; Hou, J.; Cui, R.; Guo, X.; Shi, Z.; Yang, F.; Dai, J. Phosphoproteome analysis reveals an important role for glycogen synthase kinase-3 in perfluorododecanoic acid-induced rat liver toxicity. Toxicol. Lett. 2013, 218, 61-69. [CrossRef]

78. Hu, W.Y.; Jones, P.D.; DeCoen, W.; King, L.; Fraker, P.; Newsted, J.; Giesy, J.P. Alterations in cell membrane properties caused by perfluorinated compounds. Comp. Biochem. Physiol. C 2003, 135, 77-88. [CrossRef] 
79. Ankley, G.T.; Kuehl, D.W.; Kahl, M.D.; Jensen, K.M.; Linnum, A.; Leino, R.L.; Villeneuve, D.A. Reproductive and developmental toxicity and bioconcentration of perfluorooctanesulfonate in a partial life-cycle test with the fathead minnow (Pimephales promelas). Environ. Toxicol. Chem. 2005, 24, 2316-2324. [CrossRef]

80. Seacat, A.M.; Thomford, P.J.; Hansen, K.J.; Olsen, G.W.; Case, M.T.; Butenhoff, J.L. Subchronic toxicity studies on perfluorooctanesulfonate potassium salt in cynomolgus monkeys. Toxicol. Sci. 2002, 68, 249-264. [CrossRef] [PubMed]

81. Seacat, A.M.; Thomford, P.J.; Hansen, K.J.; Clemen, L.A.; Eldridge, S.R.; Elcombe, C.R.; Butenhoff, J.L. Sub-chronic dietary toxicity of potassium perfluorooctanesulfonate in rats. Toxicology 2003, 183, 117-131. [CrossRef]

82. Liu, Z.; Lu, Y.; Shi, Y.; Wang, P.; Jones, K.; Sweetman, A.J.; Johnson, A.C.; Zhang, M.; Zhou, Y.; Lu, X.; et al. Crop bioaccumulation and human exposure of perfluoroalkyl acids through multimedia transport from a mega fluorochemical industrial park, China. Environ. Int. 2017, 106, 37-47. [CrossRef]

83. Guelfo, J.L.; Higgins, C.P. Subsurface transport potential of perfluoroalkyl acids at aqueous film-forming foam (AFFF)-impacted sites. Environ. Sci. Technol. 2013, 47, 4164-4171. [CrossRef]

84. Blaine, A.C.; Rich, C.D.; Hundal, L.S.; Lau, C.; Mills, M.A.; Harris, K.M.; Higgins, C.P. Uptake of perfluoroalkyl acids into edible crops via land applied biosolids: Field and greenhouse studies. Environ. Sci. Technol. 2013, 47, 14062-14069. [CrossRef]

85. Blaine, A.C.; Rich, C.D.; Sedlacko, E.M.; Hyland, K.C.; Stushnoff, C.; Dickenson, E.R.V.; Higgins, C.P. Perfluoroalkyl acid uptake in lettuce (Lactuca sativa) and strawberry (Fragaria ananassa) irrigated with reclaimed water. Environ. Sci. Technol. 2014, 48, 14361-14368. [CrossRef]

86. Felizeter, S.; McLachlan, M.S.; De Voogt, P. Uptake of perfluorinated alkyl acids by hydroponically grown lettuce (Lactuca sativa). Environ. Sci. Technol. 2012, 46, 11735-11743. [CrossRef] [PubMed]

87. McLachlan, M.S.; Felizeter, S.; Klein, M.; Kotthoff, M.; De Voogt, P. Fate of a perfluoroalkyl acid mixture in an agricultural soil studied in lysimeters. Chemosphere 2019, 223, 180-187. [CrossRef]

88. Vestergren, R.; Ullah, S.; Cousins, I.T.; Berger, U. A matrix effect-free method for reliable quantification of perfluoroalkyl carboxylic acids and perfluoroalkane sulfonic acids at low parts per trillion levels in dietary samples. J. Chromatogr. A 2012, 1237, 64-71. [CrossRef]

89. European Food Safety Authority. Perfluoroalkylated substances in food: Occurrence and dietary exposure. EFSA J. 2012, 10, 2743. [CrossRef]

90. Vestergren, R.; Cousins, I.T. Tracking the pathways of human exposure to perfluorocarboxylates. Environ. Sci. Technol. 2009, 43, 5565-5575. [CrossRef]

91. Calafat, A.M.; Kuklenyik, Z.; Reidy, J.A.; Caudill, S.P.; Tully, J.S.; Needham, L.L. Serum concentrations of 11 polyfluoroalkyl compounds in the U.S. population: Data from the National Health and Nutrition Examination Survey (NHANES) 1999-2000. Environ. Sci. Technol. 2007, 41, 2237-2242. [CrossRef] [PubMed]

92. Biegel, L.B.; Hurtt, M.E.; Frame, S.R.; O'Connor, J.C.; Cook, J.C. Mechanisms of extrahepatic tumor induction by peroxisome proliferators in male CD rats. Toxicol. Sci. 2001, 60, 44-55. [CrossRef]

93. U.S. Environmental Protection Agency. SAB Review of EPA's Draft Risk Assessment of Potential Human Health Effects Associated with PFOA and Its Salts. EPA-SAB-06-006. Available online: http://yosemite.epa.gov/sab/SABPRODUCT.NSF/acdfe15ab1de42e485256ead006ff442/ A3C83648E77252828525717F004B9099/\$File/sab_06_006.pdf (accessed on 2 October 2020).

94. Lundin, J.I.; Alexander, B.H.; Olsen, G.W.; Church, T.R. Ammonium perfluorooctanoate production and occupational mortality. Epidemiology 2009, 20, 921-928. [CrossRef] [PubMed]

95. Barry, V.; Winquist, A.; Steenland, K. Per Uorooctanoic Acid (PFOA) exposures and incident cancers among adults living near a chemical plant. Environ. Health Perspect. 2013, 121, 1313-1318. [CrossRef] [PubMed]

96. Leonard, R.C.; Kreckmann, K.H.; Sakr, C.J.; Symons, J.M. Retrospective cohort mortality study of workers in a polymer production plant including a reference population of regional workers. Ann. Epidemiol. 2008, 18, 15-22. [CrossRef] [PubMed]

97. Steenland, K.; Woskie, S. Cohort mortality study of workers exposed to perfluorooctanoic acid. Am. J. Epidemiol. 2012, 176, 909-917. [CrossRef] [PubMed]

98. Frisbee, S.J.; Brooks, A.P., Jr.; Maher, A.; Flensborg, P.; Arnold, S.; Fletcher, T.; Steenland, K.; Shankar, A.; Knox, S.S.; Pollard, C.; et al. The C8 health project: Design, methods, and participants. Environ. Health Perspect. 2009, 117, 1873-1882. [CrossRef] [PubMed] 
99. Pistocchi, A.; Loos, R. A map of European emissions and concentrations of PFOS and PFOA. Environ. Sci. Technol. 2009, 43, 9237-9244. [CrossRef]

100. Atkinson, C.; Blake, S.; Hall, T.; Kanda, R.; Rumsby, P. Survey of the prevalence of perfluorooctane sulphonate (PFOS), perfluorooctanoic acid (PFOA) and related compounds in drinking water and their sources. Report DEFRA 7585, Drinking Water Inspectorate, Department for Environment, Food and Rural Affairs. Available online: http://www.fwr.org/analysis/dwi0854.htm (accessed on 2 October 2020).

101. Lange, F.T.; Wenz, M.; Schmidt, C.K.; Brauch, H.J. Occurrence of perfluoroalkyl sulfonates and carboxylates in German drinking water sources compared to other countries. Water Sci. Technol. 2007, 56, 151-158. [CrossRef]

102. Gyllenhammar, I.; Berger, U.; Sundstro“m, M.; McCleaf, P.; Eure'n, K.; Eriksson, S.; Ahlgren, S.; Lignell, S. Influence of contaminated drinking water on perfluoroalkyl acid levels in human serum-A case study from Uppsala, Sweden. Environ. Res. 2015, 140, 673-683. [CrossRef]

103. Pitter, G.; DaRe, F.; Canova, C.; Barbieri, G.; ZareJeddi, M.; Daprà, F.; Manea, M.; Zolin, R.; Bettega, A.M.; Stopazzolo, G.; et al. Serum levels of perfluoroalkyl substances (PFAS) in adolescents and young adults exposed to contaminated drinking water in the Veneto Region, Italy: A cross-sectional study based on a health surveillance program. Environ. Health Perspect. 2020, 128, 27007. [CrossRef]

104. Valsecchi, S.; Babut, M.; Mazzoni, M.; Pascariello, S.; Ferrario, C.; De Felice, B.; Bettinetti, R.; Veyrand, B.; Marchand, P.; Polesello, S. Perfluoroalkyl Substances (PFAS) in Fish from European Lakes: Current contamination status, sources, and perspectives for monitoring. Environ. Toxicol. Chem. 2020. [CrossRef] [PubMed]

105. Brooke, D.; Footitt, A.; Nwaogu, T.A. Environmental Risk Evaluation Report: Perfluorooctanesulphonate (PFOS). United Kingdom: Environment Agency. 2004. Available online: https://assets.publishing.service. gov.u/kgovernment/uploads/system/uploads/attachment_data/file/290857/scho1009brbl-e-e.pdf (accessed on 2 October 2020).

106. OECD Report ENV/JM/RD. 2002. Available online: https://www.oecd.org/env/ehs/risk-assessment/2382880. pdf (accessed on 2 October 2020).

107. OECD. Results of the 2006 Survey on Production and Use of PFOS, PFAS, PFOA, PFCA, Their Related Substances and Products/Mixtures Containing These Substances; ENV/JM/MONO; OECD: Paris, France, 2006; Volume 36, p. 6.

108. Stockholm Convention on POPs. POPRC Recommendations for Listing Chemicals. Available online: http: //chm.pops.int/Convention/POPs-ReviewCommittee/Chemicals/tabid/243/language/en-US/Default.aspx (accessed on 2 October 2020).

109. European Commission. Directive 2006/122/EC of the European Parliament and of the Council of 12 December 2006 amending for the 30th time Council Directive 76/769/EEC on the approximation of the laws, regulations and administrative provisions of the member states relating to restrictions on the marketing and use of certain dangerous substances and preparations (perfluorooctane sulfonates). Off. J. Eur. Commun. 2006, 58, 32-34. Available online: https://eur-lex.europa.eu/LexUriServ/LexUriServ.do?uri=OJ:L:2006:372:0032:0034:EN:PDF (accessed on 2 October 2020).

110. Blum, A.; Balan, S.A.; Scheringer, M.; Goldenman, G.; Trier, X.; Cousins, I.T.; Diamond, M.; Higgins, C.; Avery, E.; Peaslee, G.; et al. The Madrid Statement on poly- and perfluoroalkyl substances (PFAS). Environ. Health Perspect. 2015, 123, A107-A111. [CrossRef] [PubMed]

111. United Nations Environment Programme, Stockholm Convention. Decision SC-9/12. Listing of perfluorooctanoic acid (PFOA), its salts and PFOA related compounds. In Proceedings of the Ninth Meeting of the Conference of the Parties to the Stockholm Convention, Geneva, Switzerland, 29 April-10 May 2019; Available online: http://chm.pops.int/TheConvention/ConferenceoftheParties/Meetings/COP9/tabid/7521/ Default.aspx (accessed on 2 October 2020).

112. United Nations Environment Programme, Stockholm Convention. Working Document UNEP/POPS/ POPRC.13/4. Proposal to list perfluorohexane sulfonic acid (CAS No: 355-46-4, PFHxS), its salts and PFHxSrelated compounds in Annexes A, B and/or C to the Stockholm Convention on Persistent Organic Pollutants. In Proceedings of the Thirteenth meeting of the Persistent Organic Pollutants Review Committee (POPRC.13), Rome, Italy, 17-20 October 2017; Available online: https://assets.publishing.service.gov.uk/government/ uploads/system/uploads/attachment_data/file/338258/PFOS_PFOA_General_Information_phe_v1.pdf (accessed on 2 October 2020). 
113. Public Health England, Toxicology Department. PFOS and PFOA General Information. 2009. Available online: http://www.pops.int/Default.aspx?tabid=5965 (accessed on 2 October 2020).

114. Geueke, B. FPF Dossier: Per- and polyfluoroalkyl substances (PFAS). Zenodo 2016. [CrossRef]

115. Trinkwasserkommission (German Drinking Water Commission of the Ministry of Health). Provisional Evaluation of PFT in Drinking Water with the Guide Substances Perfluorooctanoic Acid (PFOA) and Perfluorooctane Sulfonate (PFOS) as Examples. 2006. Available online: https://www.umweltbundesamt.de/ sites/default/files/medien/pdfs/pft-in-drinking-water.pdf (accessed on 2 October 2020).

116. Veneto Region. Progress and Prospects for Veneto Agriculture. 2014. Available online: http://statistica.regione. veneto.it/ENG/Pubblicazioni/RapportoStatistico2014/pdf/Capitolo07.pdf (accessed on 2 October 2020).

117. Nicoletto, C.; Maucieri, C.; Sambo, P. Effects on water management and quality characteristics of ozone application in chicory forcing process: A pilot system. Agronomy 2017, 7, 29. [CrossRef]

118. WHO. Keeping Our Water Clean: The Case of Water Contamination in the Veneto Region, Italy. World Health Organization. 2017. Available online: https://www.euro.who.int/_data/assets/pdf_file/0019/341074/pfasreport-20170606-h1330-print-isbn.pdf (accessed on 2 October 2020).

119. ARPAV. Concentrations of the Perfluoroalkyl Substances in the Waters of Veneto Region, Open Data on PFAS Monitoring, from 02/07/2013 to 20/09/2018. 2018. Available online: http://www.arpa.veneto.it/dati-ambientali/ open-dataidrosfera/concentrazione-di-sostanze-perfluoroalchiliche-pfas-nelle-acqueprelevate-da-arpav (accessed on 2 October 2020).

120. Mastrantonio, M.; Bai, E.; Uccelli, R.; Cordiano, V.; Screpanti, A.; Crosignani, P. Drinking water contamination from perfluoroalkyl substances (PFAS): An ecological mortality study in the Veneto Region, Italy. Eur. J. Public Health 2018, 28, 180-185. [CrossRef]

121. Darrow, L.A.; Stein, C.R.; Steenland, K. Serum perfluorooctanoic acid and per- fluoro octane sulfonate concentrations in relation to birth outcomes in the Mid- Ohio Valley, 2005-2010. Environ. Health Perspect. 2013, 121, 1207-1213. [CrossRef]

122. Webster, E.; Ellis, D.A.; Reid, L.K. Modeling the environmental fate of perfluorooctanoic acid and perfluorooctanoate: An investigation of the role of individual species partitioning. Environ. Toxicol. Chem. 2010, 29, 1466-1475. [CrossRef]

123. Giesy, J.P.; Kannan, K. Global distribution of perfluorooctane sulfonate in wildlife. Environ. Sci. Technol. 2001, 35, 1339-1342. [CrossRef]

124. Grandjean, P. Health status of workers exposed to perfluorinated alkylate substances. J. Occup. Environ. Med. 2018, 60, e562. [CrossRef]

125. Taves, D.R. Evidence that there are two forms of fluoride in human serum. Nature 1968, 217, 1050. [CrossRef]

126. Taves, D.R. Comparison of "organic" fluoride in human and nonhuman serums. J. Dent. Res. 1971, $50,783$. [CrossRef]

127. Shen, Y.W.; Taves, D.R. Fluoride concentrations in the human placenta and maternal and cord blood. An. J. Obstet. Gynecol. 1974, 119, 205-207. [CrossRef]

128. Guy, W.S.; Taves, D.R.; Brey, W.S., Jr. Organic Fluorocompounds in Human Plasma: Prevalence and Characterization. In Biochemistry Involving Carbon-Fluorine Bonds; Filler, R., Ed.; ACS Publications: Washington, DC, USA, 1979; Volume 28, pp. 117-134. [CrossRef]

129. Ubel, F.A.; Sorenson, S.; Roach, D. Health status of plant workers exposed to fluorochemicals-a preliminary report. Am. Ind. Hyg. Assoc. J. 1980, 41, 584-589. [CrossRef] [PubMed]

130. Gilliland, F.D. Fluorocarbons and Human Health: Studies in an Occupational Cohort. Ph.D. Thesis, University of Minnesota, Minneapolis, MN, USA, 1992.

131. Gilliland, F.D.; Mandel, J.S. Peripheral Blood Lymphocyte Count in Men Occupationally Exposed to Perfluorooctanoic Acid. Personal Communication. 1993. Available online: https://www.ag.state.mn.us/ Office/Cases/3M/docs/PTX/PTX2498.pdf (accessed on 2 October 2020).

132. Gilliland, F.D.; Mandel, J.S. Mortality among employees of a perfluorooctanoic acid production plant. J. Occup. Med. 1993, 35, 950-954. [CrossRef] [PubMed]

133. Gilliland, F.D.; Mandel, J.S. Serum perfluorooctanoic acid and hepatic enzymes, lipoproteins and cholesterol: A study of occupationally exposed men. Am. J. Ind. Med. 1996, 29, 560-568. [CrossRef]

134. 3M. Perfluorooctane Sulfonate: Current Summary of Human Sera, Health and Toxicological Data; U.S. EPA Administrative Record AR226-0548; 3M: Saint Paul, MN, USA, 1999. 
135. Calafat, A.M.; Wong, L.Y.; Kuklenyik, Z.; Reidy, J.A.; Needham, L.L. Polyfluoroalkyl chemicals in the U.S. population: Data from the National Health and Nutrition Examination Survey (NHANES) 2003-2004 and comparisons with NHANES 1999-2000. Environ. Health Perspect. 2007, 115, 1596-1602. [CrossRef]

136. Andrews, D.; Walker, B. Poisoned Legacy. Know Your Environment: Protect Your Health. 2015. Available online: https://www.ewg.org/research/poisoned-legacy (accessed on 2 October 2020).

137. Scheringer, M.; Trier, X.; Cousins, I.T.; de Voogt, P.; Fletcher, T.; Wang, Z.; Webster, T.F. Helsingør statement on poly- and perfluorinated alkyl substances (PFAS). Chemosphere 2014, 114, 337-339. [CrossRef] [PubMed]

138. Ritscher, A.; Wang, Z.; Scheringer, M.; Boucher, J.M.; Ahrens, L.; Berger, U.; Bintein, S.; Bopp, S.K.; Borg, D.; Buser, A.M.; et al. Zürich statement on future actions on per- and polyfluoroalkyl substances (PFAS). Environ. Health Perspect. 2018, 126, 84502. [CrossRef]

139. CDC. Center for Disease Control and Prevention: National Health and Nutrition Examination Survey. 2009-2010 Data Documentation, Codebook, and Frequencies. 2013, Polyfluoroalkyl Chemicals (PFC_F). Available online: http://wwwn.cdc.gov/nchs/nhanes/2009-2010/PFC_F.htm (accessed on 2 October 2020).

140. Kato, K.; Wong, L.Y.; Jia, L.T.; Kuklenyik, Z.; Calafat, A.M. Trends in exposure to polyfluoroalkyl chemicals in the U.S. population: 1999-2008. Environ. Sci. Technol. 2011, 45, 8037-8045. [CrossRef]

141. Axmon, A.; Axelsson, J.; Jakobsson, K.; Lindh, C.H.; Jönsson, B.A. Time trends between 1987 and 2007 for perfluoroalkyl acids in plasma from Swedish women. Chemosphere 2014, 102, 61-67. [CrossRef] [PubMed]

142. Glynn, A.; Berger, U.; Bignert, A.; Ullah, S.; Aune, M.; Lignell, S.; Darnerud, P.O. Perfluorinated alkyl acids in blood serum from primiparous women in Sweden: Serial sampling during pregnancy and nursing, and temporal trends 1996-2010. Environ. Sci. Technol. 2012, 46, 9071-9079. [CrossRef]

143. Gebbink, W.A.; Berger, U.; Cousins, I.T. Estimating human exposure to PFOS isomers and PFCA homologues: The relative importance of direct and indirect (precursor) exposure. Environ. Int. 2015, 74, 160-169. [CrossRef]

144. Nøst, T.H.; Vestergren, R.; Berg, V.; Nieboer, E.; Odland, J.Ø.; Sandanger, T.M. Repeated measurements of per- and polyfluoroalkyl substances (PFAS) from 1979 to 2007 in males from Northern Norway: Assessing time trends, compound correlations and relations to age/birth cohort. Environ Int. 2014, 67, 43-53. [CrossRef]

145. Bjerregaard-Olsen, C.; Bach, C.C.; Long, M.; Ghisari, M.; Bossi, R.; Bech, B.H.; Nohr, E.A.; Henriksen, T.B.; Olsen, J.; Bonefeld-Jørgensen, E.C. Time trends of perfluorinated alkyl acids in serum from Danish pregnant women 2008-2013. Environ. Int. 2016, 91, 14-21. [CrossRef]

146. Schröter-Kermani, C.; Müller, J.; Jürling, H.; Conrad, A.; Schulte, C. Retrospective monitoring of perfluorocarboxylates and perfluorosulfonates in human plasma archived by the German Environmental Specimen Bank. Int. J. Hyg. Environ. Health 2016, 6, 633-640. [CrossRef]

147. Yeung, L.W.Y.; Robinson, S.J.; Koschorreck, J.; Mabury, S.A. Part I. A temporal study of PFCAs and their precursors in human plasma from two German cities 1982-2009. Environ. Sci. Technol. 2013, 47, 3865-3874. [CrossRef]

148. Yeung, L.W.Y.; Robinson, S.J.; Koschorreck, J.; Mabury, S.A. Part II. A temporal study of PFOS and its precursors in human plasma from two German cities in 1982-2009. Environ. Sci. Technol. 2013, 47, 3875-3882. [CrossRef]

149. Toms, L.M.L.; Thompson, J.; Rotander, A.; Hobson, P.; Calafat, A.M.; Kato, K.; Ye, X.; Broomhall, S.; Harden, F.; Mueller, J.F. Decline in perfluorooctane sulfonate and perfluorooctanoate serum concentrations in an Australian population from 2002 to 2011. Environ. Int. 2014, 71, 74-80. [CrossRef]

150. Hölzer, J.; Midasch, O.; Rauchfuss, K.; Kraft, M.; Reupert, R.; Angerer, J.; Kleeschulte, P.; Marschall, N.; Wilhelm, M. Biomonitoring of perfluorinated compounds in children and adults exposed to perfluorooctanoate-contaminated drinking water. Environ. Health Perspect. 2008, 116, 651-657. [CrossRef]

151. Okada, E.; Kashino, I.; Matsuura, H.; Sasaki, S.; Miyashita, C.; Yamamoto, J.; Ikeno, T.; Ito, Y.M.; Matsumura, T.; Tamakoshi, A.; et al. Temporal trends of perfluoroalkyl acids in plasma samples of pregnant women in Hokkaido, Japan, 2003-2011. Environ. Int. 2013, 60, 89-96. [CrossRef]

152. Harada, K.H.; Yang, H.R.; Moon, C.S.; Hung, N.N.; Hitomi, T.; Inoue, K.; Niisoe, T.; Watanabe, T.; Kamiyama, S.; Takenaka, K.; et al. Levels of perfluorooctane sulfonate and perfluorooctanoic acid in female serum samples from Japan in 2008, Korea in 1994-2008 and Vietnam in 2007-2008. Chemosphere 2010, 79, 314-319. [CrossRef]

153. Yeung, L.W.Y.; So, M.K.; Jiang, G.B.; Taniyasu, S.; Yamashita, N.; Song, M.Y.; Wu, Y.N.; Li, J.G.; Giesy, J.P.; Guruge, K.S.; et al. Perfluorooctanesulfonate and related fluorochemicals in human blood samples from China. Environ. Sci. Technol. 2006, 40, 715-720. [CrossRef] [PubMed] 
154. Pan, Y.Y.; Shi, Y.L.; Wang, J.; Cai, Y.; Wu, Y. Concentrations of perfluorinated compounds in human blood from twelve cities in China. Environ. Toxicol. Chem. 2010, 29, 2695-2701. [CrossRef]

155. Ingelido, A.M.; Marra, V.; Abballe, A.; Valentini, S.; Iacovella, N.; Barbieri, P.; Porpora, M.G.; Domenico, A.D.; De Felip, E. Perfluorooctanesulfonate and perfluorooctanoic acid exposures of the Italian general population. Chemosphere 2010, 80, 1125-1130. [CrossRef]

156. Olsen, G.W.; Church, T.R.; Miller, J.P.; Burris, J.M.; Hansen, K.J.; Lundberg, J.K.; Armitage, J.B.; Herron, R.M.; Medhdizadehkashi, Z.; Nobiletti, J.B.; et al. Perfluorooctanesulfonate and other fluorochemicals in the serum of American Red Cross adult blood donors. Environ. Health Perspect. 2003, 111, 1892-1901. [CrossRef]

157. Toms, L.M.; Calafat, A.; Kato, K.; Thompson, J.; Harden, F.; Hobson, P.; Sjodin, A.; Jochen, A.; Mueller, F. Polyfluoroalkyl Chemicals in pooled blood serum from infants, children and adults in Australia. Environ. Sci. Technol. 2009, 43, 4194-4199. [CrossRef] [PubMed]

158. Harada, K.; Saito, N.; Inoue, K.; Yoshinaga, T.; Watanabe, T.; Sasaki, S.; Kamiyama, S.; Koizumi, A. The influence of time, sex and geographic factors on levels of perfluorooctane sulfonate and perfluorooctanoate in human serum over the last 25 years. J. Occup. Health 2004, 46, 141-147. [CrossRef]

159. Midasch, O.; Schettgen, T.; Angerer, J. Pilot study on the perfluorooctanesulfonate and perfluorooctanoate exposure of the German general population. Int. J. Environ. Health 2006, 209, 489-496. [CrossRef]

160. Wilhelma, M.; Angererb, J.; Frommec, H.; Holzera, J. Contribution to the evaluation of reference values for PFOA and PFOS in plasma of children and adults from Germany. Int. J. Hyg. Environ. Health 2009, 212, 56-60. [CrossRef]

161. Ericson, I.; Gómez, M.; Nadal, M.; Van Bavel, B.; Lindström, G.; Domingo, J.L. Perfluorinated chemicals in blood of residents in Catalonia (Spain) in relation to age and gender: A pilot study. Environ. Int. 2007, 33, 616-623. [CrossRef] [PubMed]

162. Kannan, K.; Corsolini, S.; Falandysz, J.; Fillmann, G.; Kumar, K.S.; Loganathan, B.G.; Mustafa, A.M.; Olivero, J.; Van Wouwe, N.; Yang, J.H.; et al. Perfluorooctanesulfonate and related fluorochemicals in human blood from several countries. Environ. Sci. Technol. 2004, 38, 4489-4495. [CrossRef] [PubMed]

163. Tomy, G.T.; Tittlemier, S.A.; Palace, V.P.; Budakowski, W.R.; Braekevelt, E.; Brinkworth, L.; Friesen, K. Biotransformation of $\mathrm{N}$-ethyl perfluorooctanesulfonamide by rainbow trout (Onchorhynchus mykiss) liver microsomes. Environ. Sci. Technol. 2004, 38, 758-762. [CrossRef]

164. EFSA. Perfluorooctane sulfonate (PFOS), perfluorooctanoic acid (PFOA) and their salts. Scientific opinion of the panel on contaminants in the food chain. EFSA J. 2008, 653, 1-131. [CrossRef]

165. Fromme, H.; Midasch, O.; Twardella, D.; Angerer, J.; Boehmer, S.; Liebl, B. Occurrence of perfluorinated substances in an adult German population in southern Bavaria. Int. Arch. Occup. Environ. Health 2007, 80, 313-319. [CrossRef]

166. De Felip, E.; Abballe, A.; Albano, F.L.; Battista, T.; Carraro, V.; Conversano, M.; Franchini, S.; Giambanco, L.; Iacovella, N.; Ingelido, A.M.; et al. Current exposure of Italian women of reproductive age to PFOS and PFOA: A human biomonitoring study. Chemosphere 2015, 137, 1-8. [CrossRef]

167. Li, Y.; Fletcher, T.; Mucs, D.; Scott, K.; Lindh, C.H.; Tallving, P.; Jakobsson, K. Half-lives of PFOS, PFHxS and PFOA after end of exposure to contaminated drinking water. Occup. Environ. Med. 2018, 75, 46-51. [CrossRef]

168. Polesello, S.; Pagnotta, R.; Marziali, L.; Patrolecco, L.; Rusconi, M.; Stefani, F.; Valsecchi, S. Realizzazione di uno Studio di Valutazione del Rischio Ambientale e Sanitario Associato alla Contaminazione da Sostanze Perfluoro-Alchiliche (PFAS) nel Bacino del Po e nei Principali Bacini Fluviali Italiani. 2013, Relazione Finale. Available online: http://www.minambiente.it/sites/default/files/archivio/allegati/reach/progettoPFAS_ ottobre2013.pdf (accessed on 2 October 2020).

169. Valsecchi, S.; Rusconi, M.; Mazzoni, M.; Viviano, G.; Pagnotta, R.; Zaghi, C.; Serrini, G.; Polesello, S. Occurrence and sources of perfluoroalkyl acids in Italian river basins. Chemosphere 2015, 129, $126-134$. [CrossRef] [PubMed]

170. Ingelido, A.M.; Abballe, A.; Gemma, S.; Dellatte, E.; Iacovella, N.; DeAngelis, G.; Zampaglioni, F.; Marra, V.; Miniero, R.; Valentini, S.; et al. Biomonitoring of perfluorinated compounds in adults exposed to contaminated drinking water in the Veneto Region, Italy. Environ Int. 2018, 110, 149-159. [CrossRef]

171. U.S. EPA. Drinking Water Health Advisory for Perfluorooctanoic Acid (PFOA). 2016. Available online: https: //www.epa.gov/sites/production/files/2016-05/documents/pfoa_health_advisory_final_508.pdf (accessed on 2 October 2020). 
172. U.S. EPA. Drinking Water Health Advisory for Perfluorooctane Sulfonate (PFOS). 2016. Available online: https: //www.epa.gov/sites/production/files/2016-05/documents/pfos_health_advisory_final_508.pdf (accessed on 2 October 2020).

173. Danish Environmental Protection Agency. Perfluoroalkylated Substances: PFOA, PFOS and PFOSA Evaluation of Health Hazards and Proposal of a Health Based Quality Criterion for Drinking Water, Soil and Ground Water. Environmental Project No.1665. 2015, p. 2015. Available online: http://www2.mst.dk/Udgiv/ publications/2015/04/978-87-93283-01-5.pdf (accessed on 2 October 2020).

174. Health Council of the Netherlands. Perfluorooctanoic Acid and Its Salts. Evaluation of the Carcinogenicity and Genotoxicity. 2013. Publication no. 2013/32. Available online: https://www.gezondheidsraad.nl/sites/ default/files/201332Perfluorooctanoic_acid_and_its_salts.pdf (accessed on 2 October 2020).

175. Girardi, P.; Merler, E. A mortality study on male subjects exposed to polyfluoroalkyl acids with high internal dose of perfluorooctanoic acid. Environ. Res. 2019, 179, 108743. [CrossRef]

176. Crebelli, R.; Caiola, S.; Conti, L.; Cordelli, E.; De Luca, G.; Dellatte, E.; Eleuteri, P.; Iacovella, N.; Leopardi, P.; Marcon, F.; et al. Can sustained exposure to PFAS trigger a genotoxic response? A comprehensive genotoxicity assessment in mice after subacute oral administration of PFOA and PFBA. Regul. Toxicol. Pharmacol. 2019, 106, 169-177. [CrossRef] [PubMed]

177. Costa, G.; Sartori, S.; Consonni, D. Thirty years of medical surveillance in perfluorooctanoic acid production workers. J. Occup. Environ. Med. 2009, 51, 364-372. [CrossRef] [PubMed]

178. Salihovic, S.; Stubleski, J.; Kärrman, A.; Larsson, A.; Fall, T.; Lind, L. Changes in markers of liver function in relation to changes in perfluoroalkyl substances-A longitudinal study. Environ. Int. 2018, 117, 196-203. [CrossRef]

179. Gallo, V.; Leonardi, G.; Genser, B.; Lopez-Espinosa, M.-J.; Frisbee, S.J.; Karlsson, L.; Ducatman, A.M.; Fletcher, T. Serum perfluorooctanoate (PFOA) and perfluorooctane sulfonate (PFOS) concentrations and liver function biomarkers in a population with elevated PFOA exposure. Environ. Health Perspect. 2012, 120. [CrossRef]

180. Darrow, L.A.; Groth, A.C.; Winquist, A.; Shin, H.-M.; Bartell, S.M.; Steenland, K. Modeled perfluorooctanoic acid (PFOA) exposure and liver function in a Mid-Ohio valley community. Environ. Health Perspect. 2016, 124. [CrossRef]

181. Post, G.B.; Cohn, P.D.; Cooper, K.R. Perfluorooctanoic acid (PFOA), an emerging drinking water contaminant: A critical review of recent literature. Environ. Res. 2012, 116, 93-117. [CrossRef] [PubMed]

182. IARC Working Group on the Evaluation of Carcinogenic Risks to Humans. Polychlorinated Biphenyls and Polybrominated Biphenyls; IARC Monographs on the Evaluation of Carcinogenic Risks to Humans, No. 107; International Agency for Research on Cancer: Lyon, France, 2016.

183. Abdellatif, A.; Al-Tonsy, A.H.; Awad, M.E.; Roberfroid, M.; Khan, M.N. Peroxisomal enzymes and 8-hydroxydeoxyguanosine in rat liver treated with perfluorooctanoic acid. Dis. Markers 2003, 19, $19-25$. [CrossRef]

184. Liu, C.; Yu, K.; Shi, X.; Wang, J.; Lam, P.K.; Wu, R.S.; Zhou, B. Induction of oxidative stress and apoptosis by PFOS and PFOA in primary cultured hepatocytes of freshwater tilapia (Oreochromis niloticus). Aquat. Toxicol. 2007, 82, 135-143. [CrossRef]

185. Panaretakis, T.; Shabalina, I.G.; Grandér, D.; Shoshan, M.C.; DePierre, J.W. Reactive oxygen species and mitochondria mediate the induction of apoptosis in human hepatoma HepG2 cells by the rodent peroxisome proliferator and hepatocarcinogen, perfluorooctanoic acid. Toxicol. Appl. Pharmacol. 2001, 173, 56-64. [CrossRef]

186. Yao, X.; Zhong, L. Genotoxic risk and oxidative DNA damage in HepG2 cells exposed to perfluorooctanoic acid. Mutat. Res. 2005, 587, 38-44. [CrossRef]

187. Wang, X.; Liu, L.; Zhang, W.; Zhang, J.; Du, X.; Huang, Q.; Tian, M.; Shen, H. Serum metabolome biomarkers associate low-level environmental perfluorinated compound exposure with oxidative /nitrosative stress in humans. Environ. Pollut. 2017, 229, 168-176. [CrossRef] [PubMed]

188. Pandey, K.B.; Rizvi, S.I. Markers of oxidative stress in erythrocytes and plasma during aging in humans. Oxid. Med. Cell. Longev. 2010, 3, 2-12. [CrossRef] [PubMed]

189. Barnham, K.J.; Masters, C.L.; Bush, A.I. Neurodegenerative diseases and oxidative stress. Nat. Rev. Drug Discov. 2004, 3, 205-214. [CrossRef] [PubMed]

190. Visconti, R.; Grieco, D. New insights on oxidative stress in cancer. Curr. Opin. Drug Discov. 2009, 12, $240-245$. 
191. Tsutsui, H.; Kinugawa, S.; Matsushima, S. Oxidative stress and heart failure. Am. J. Physiol. Heart Circ. Physiol. 2011, 301, H2181-H2190. [CrossRef] [PubMed]

192. Hu, X.Z.; Hu, D.C. Effects of perfluorooctanoate and perfluorooctane sulfonate exposure on hepatoma Hep G2 cells. Arch. Toxicol. 2009, 83, 851-861. [CrossRef]

193. Harman, D. Origin and evolution of the free radical theory of aging: A brief personal history. Biogerontology 2009, 10, 773-781. [CrossRef] [PubMed]

194. Mates, J.M.; Segura, J.A.; Alonso, F.J.; Márquez, J. Roles of dioxins and heavy metals in cancer and neurological diseases using ROS-mediated mechanisms. Free Radic. Biol. Med. 2010, 49, 1328-1341. [CrossRef]

195. Santovito, G.; Trentin, E.; Gobbi, I.; Bisaccia, P.; Tallandini, I.; Irato, P. Non-enzymatic antioxidant responses of Mytilus galloprovincialis: Insights into the physiological role against metal-induced oxidative stress risk. Comp. Biochem. Physiol. C 2020, 240, 108909. [CrossRef]

196. Wielsøe, M.; Long, M.; Ghisari, M.; Bonefeld-Jørgensen, E.C. Perfluoroalkylated substances (PFAS) affect oxidative stress biomarkers in vitro. Chemosphere 2015, 129, 239-245. [CrossRef]

197. Zeng, Z.; Song, B.; Xiao, R.; Zeng, G.; Gong, J.; Chen, M.; Xu, P.; Zhang, P.; Shen, M.; Yi, H. Assessing the human health risks of perfluorooctane sulfonate by in vivo and in vitro studies. Environ. Int. 2019, 126, 598-610. [CrossRef] [PubMed]

198. Aruoma, O.K. Free radicals, oxidative stress, and antioxidants in human health and disease. J. Am. Oil Chem. Soc. 1998, 75, 199-212. [CrossRef] [PubMed]

199. Cooke, M.S.; Evans, M.D.; Dizdaroglu, M.; Lunec, J. Oxidative DNA damage: Mechanisms, mutation, and disease. FASEB J. 2003, 17, 1195-1214. [CrossRef] [PubMed]

200. Suh, K.S.; Choi, E.M.; Kim, Y.J.; Hong, S.M.; Park, S.Y.; Rhee, S.Y.; Oh, S.; Kim, S.W.; Pak, Y.K.; Choe, W.; et al. Perfluorooctanoic acid induces oxidative damage and mitochondrial dysfunction in pancreatic $\beta$-cells. Mol. Med. Rep. 2017, 15, 3871-3878. [CrossRef]

201. Watkins, A.M.; Wood, C.R.; Lin, M.T.; Abbott, B.D. The effects of perfluorinated chemicals on adipocyte differentiation in vitro. Mol. Cell. Endocrin. 2015, 400, 90-101. [CrossRef]

202. Henry, N.D.; Fair, P.A. Comparison of in vitro cytotoxicity, estrogenicity and antiestrogenicity of triclosan, perfluorooctane sulfonate and perfluorooctanoic acid. J. Appl. Toxicol. 2013, 33, 265-272. [CrossRef]

203. Kraugerud, M.; Zimmer, K.E.; Ropstad, E.; Verhaegen, S. Perfluorinated compounds differentially affect steroidogenesis and viability in the human adrenocortical carcinoma (H295R) in vitro cell assay. Toxicol. Lett. 2011, 205, 62-68. [CrossRef]

204. Kamendulis, L.M.; Wu, Q.; Sandusky, G.E.; Hocevar, B.A. Perfluorooctanoic acid exposure triggers oxidative stress in the mouse pancreas. Toxicol. Rep. 2014, 1, 513-521. [CrossRef]

205. Klaunig, J.E.; Babich, M.A.; Baetcke, K.P.; Cook, J.C.; Corton, J.C.; David, R.M.; DeLuca, J.G.; Lai, D.Y.; McKee, R.H.; Peters, J.M.; et al. PPAR $\alpha$ agonist-induced rodent tumors: Modes of action and human relevance. Crit. Rev. Toxicol. 2003, 33, 655-780. [CrossRef]

206. Andersen, M.E.; Butenhoff, J.L.; Chang, S.-C.; Farrar, D.G.; Kennedy, G.L., Jr.; Lau, C.; Olsen, G.W.; Seed, J.; Wallace, K.B. Perfluoroalkyl acids and related chemistries-Toxicokinetics and mode of action. Toxicol. Sci. 2008, 102, 3-14. [CrossRef]

207. Intrasuksri, U.; Rangwala, S.M.; O’Brien, M.; Noonan, D.J.; Feller, D.R. Mechanisms of peroxisome proliferation by perfluorooctanoic acid and endogenous fatty acids. Gen. Pharmacol. 1998, 31, 187-197. [CrossRef]

208. Sohlenius, A.K.; Eriksson, A.M.; Högström, C.; Kimland, M.; DePierre, J.W. Perfluorooctane sulfonic acid is a potent inducer of peroxisomal fatty acid b-oxidation and other activities known to be affected by peroxisome proliferators in mouse liver. Pharmacol. Toxicol. 1993, 72, 90-93. [CrossRef] [PubMed]

209. Rosen, M.B.; Lee, J.S.; Ren, H.; Vallanat, B.; Liu, J.; Waalkes, M.P.; Abbott, B.D.; Lau, C.; Corton, J.C. Toxicogenomic dissection of the perfluorooctanoic acid transcript profile in mouse liver: Evidence for the involvement of nuclear receptors PPAR $\alpha$ and CAR. Toxicol. Sci. 2008, 103, 46-56. [CrossRef]

210. Buhrke, T.; Kibellus, A.; Lampen, A. In vitro toxicological characterization of perfluorinated carboxylic acids with different carbon chain lengths. Toxicol. Lett. 2013, 218, 97-104. [CrossRef]

211. Vanden Heuvel, J.P.; Thompson, J.T.; Frame, S.R.; Gillies, P.J. Differential activation of nuclear receptors by perfluorinated fatty acid analogs and natural fatty acids: A comparison of human, mouse, and rat peroxisome proliferator-activated receptor-a, b, and c, liver $X$ receptor-b, and retinoid X receptor-a. Toxicol. Sci. 2006, 92, 476-489. [CrossRef] 
212. Berger, J.; Moller, D.E. The mechanisms of action of PPARs. Annu. Rev. Med. 2002, 53, 409-435. [CrossRef]

213. Melzer, D.; Rice, N.; Depledge, M.H.; Henley, W.E.; Galloway, T.S. Association between serum perfluorooctanoic acid (PFOA) and thyroid disease in the U.S. National Health and Nutrition Examination Survey. Environ. Health Perspect. 2010, 118, 686-692. [CrossRef]

214. Olsen, G.W.; Burlew, M.; Burris, J.; Mandel, J. A Cross-Sectional Analysis of Serum Perfluorooctanesulfonate (PFOS) and Perfluorooctanoate (PFOA) in Relation to Clinical Chemistry, Thyroid Hormone, Hematology and Urinalysis Results from Male and Female Employee Participants of the 2000 Antwerp and Decatur Fluorochemical Medical Surveillance Program 3M Company; Final Report; AR-226-1087; U.S. Environmental Protection Agency: Washington, DC, USA, 2001.

215. Wen, L.-L.; Lin, L.-Y.; Su, T.-C.; Chen, P.-C.; Lin, C.-Y. Association between serum perfluorinated chemicals and thyroid function in U.S. adults: The national health and nutrition examination survey 2007-2010. J. Clin. Endocrin. Metab 2013, 98, E1456-E1464. [CrossRef]

216. Shankar, A.; Xiao, J.; Ducatman, A. Perfluoroalkyl chemicals and chronic kidney disease in us adults. Am. J. Epidem. 2011, 174, 893-900. [CrossRef]

217. Watkins, D.J.; Josson, J.; Elston, B.; Bartell, S.M.; Shin, H.-M.; Vieira, V.M.; Savitz, D.A.; Fletcher, T.; Wellenius, G.A. Exposure to perfluoroalkyl acids and markers of kidney function among children and adolescents living near a chemical plant. Environ. Health Perspect. 2013, 121, 625. [CrossRef]

218. Fisher, M.; Arbuckle, T.E.; Wade, M.; Haines, D.A. Do perfluoroalkyl substances affect metabolic function and plasma lipids? Analysis of the 2007-2009, Canadian Health Measures Survey (CHMS) cycle 1. Environ. Res. 2013, 121, 95-103. [CrossRef] [PubMed]

219. Lin, C.Y.; Chen, P.C.; Lin, Y.C.; Lin, L.Y. Association among serum perfluoroalkyl chemicals, glucose homeostasis, and metabolic syndrome in adolescents and adults. Diabetes Care 2009, 32, 702-707. [CrossRef]

220. Olsen, G.W.; Gilliland, F.D.; Burlew, M.M.; Burris, J.M.; Mandel, J.S.; Mandel, J.H. An epidemiologic investigation of reproductive hormones in men with occupational exposure to perfluorooctanoic acid. J. Occupat. Environ. Med. 1998, 40, 614-622. [CrossRef]

221. Itoh, S.; Araki, A.; Mitsui, T.; Miyashita, C.; Goudarzi, H.; Sasaki, S.; Cho, K.; Nakazawa, H.; Iwasaki, Y.; Shinohara, N.; et al. Association of perfluoroalkyl substances exposure in utero with reproductive hormone levels in cord blood in the Hokkaido study on environment children's health. Environ. Int. 2016, 94, 51-59. [CrossRef] [PubMed]

222. Goudarzi, H.; Araki, A.; Itoh, S.; Sasaki, S.; Miyashita, C.; Mitsui, T.; Nakazawa, H.; Nonomura, K.; Kishi, R. The association of prenatal exposure to perfluorinated chemicals with glucocorticoid and androgenic hormones in cord blood samples: The Hokkaido study. Environ. Health Perspect. 2017, 125, 111-118. [CrossRef] [PubMed]

223. Minatoya, M.; Itoh, S.; Miyashita, C.; Araki, A.; Sasaki, S.; Miura, R.; Goudarzi, H.; Iwasaki, Y.; Kishi, R. Association of prenatal exposure to perfluoroalkyl substances with cord blood adipokines and birth size: The Hokkaido study on environment and children's health. Environ. Res. 2017, 156, 175-182. [CrossRef] [PubMed]

224. Okada, E.; Sasaki, S.; Kashino, I.; Matsuura, H.; Miyashita, C.; Kobayashi, S.; Itoh, K.; Ikeno, T.; Tamakoshi, A.; Kishi, R. Prenatal exposure to perfluoroalkyl acids and allergic diseases in early childhood. Environ. Int. 2014, 65, 127-134. [CrossRef]

225. Kishi, R.; Nakajima, T.; Goudarzi, H.; Kobayashi, S.; Sasaki, S.; Okada, E.; Miyashita, C.; Itoh, S.; Araki, A.; Ikeno, T.; et al. The association of prenatal exposure to perfluorinated chemicals with maternal essential and long-chain polyunsaturated fatty acids during pregnancy and the birth weight of their offspring: The Hokkaido study. Environ. Health Perspect. 2015, 123, 1038-1045. [CrossRef]

226. Pérez, F.; Nadal, M.; Navarro-Ortega, A.; Fàbrega, F.; Domingo, J.L.; Barceló, D.; Farré, M. Accumulation of perfluoroalkyl substances in human tissues. Environ. Int. 2013, 59, 354-362. [CrossRef]

227. Cargnelutti, F.; Di Nisio, A.; Pallotti, F.; Sabovic, I.; Spaziani, M.; Tarsitano, M.G.; Paoli, D.; Foresta, C. Effects of endocrine disruptors on foetal testis development, male puberty, and transition age. Endocrine 2020. [CrossRef]

228. Di Nisio, A.; Foresta, C. Water and soil pollution as determinant of water and food quality/contamination and its impact on male fertility. Repr. Biol. End. 2019, 17, 4. [CrossRef] [PubMed] 
229. Hauser, R.; Skakkebaek, N.E.; Hass, U.; Toppari, J.; Juul, A.; Andersson, A.M.; Kortenkamp, A.; Heindel, J.J.; Trasande, L. Male reproductive disorders, diseases and costs of exposure to endocrine-disrupting chemicals in the European Union. J. Clin. Endocrinol. Metab 2015, 100, 1267-1277. [CrossRef] [PubMed]

230. Darbandi, M.; Darbandi, S.; Agarwal, A.; Sengupta, P.; Durairajanayagam, D.; Henkel, R.; Sadeghi, M.R. Reactive oxygen species and male reproductive hormones. Reprod. Biol. Endocrinol. 2018, 16, 87. [CrossRef]

231. Beattie, M.C.; Chen, H.; Fan, J.; Papadopoulos, V.; Miller, P.; Zirkin, R.P. Aging and luteinizing hormone effects on reactive oxygen species production and DNA damage in rat Leydig cells. Biol. Reprod. 2013, 88, 1-7. [CrossRef]

232. Tostes, R.C.; Carneiro, F.S.; Carvalho, M.H.C.; Reckelhoff, J.F. Reactive oxygen species: Players in the cardiovascular effects of testosterone. Am. J. Physiol. Regul. Integr. Comp. Physiol. 2015, 310, R1-R14. [CrossRef] [PubMed]

233. Shi, Z.; Zhang, H.; Liu, Y.; Xu, M.; Dai, J. Alterations in gene expression and testosterone synthesis in the testes of male rats exposed to perfluorododecanoic acid. Tox. Sci. 2007, 98, 206-215. [CrossRef]

234. Wan, H.T.; Zhao, Y.G.; Wong, M.H.; Lee, K.F.; Yeung, W.S.B.; Giesy, J.P.; Wong, K.C.K. Testicular signaling is the potential target of perfluorooctanesulfonate-mediated subfertility in male mice. Biol. Repr. 2011, 84, 1016-1023. [CrossRef]

235. Zhang, H.; Lu, Y.; Luo, B.; Yan, S.; Guo, X.; Dai, J. Proteomic analysis of muse testis reveals perfluorooctanoic acid-induced reproductive dysfunction via direct disturbance of testicular steroidogenic machinery. J. Prot. Res. 2014, 13, 3370-3385. [CrossRef]

236. Baker, H.; Burger, H.; de Kretser, D.; Hudson, B.; Santen, R.J.; Swerdloff, R.S. Relative Incidence of Etiologic Disorders in Male Infertility. In Male Reproductive Dysfunction: Diagnosis and Management of Hypogonadism, Infertility and Impotence; Santen, R.J., Swerdloff, R.S., Eds.; Marcel Dekker Inc.: New York, NY, USA, 1986; pp. 341-372.

237. Bisht, S.; Faiq, M.; Tolahunase, M.; Dada, R. Oxidative stress and male infertility. Nat. Rev. Urol. 2017, 14, 470-485. [CrossRef]

238. Ramalho-Santos, J.; Varum, S.; Amaral, S.; Mota, P.C.; Sousa, A.P.; Amaral, A. Mitochondrial functionality in reproduction: From gonads and gametes to embryos and embryonic stem cells. Hum. Reprod. Update 2009, 15, 553-572. [CrossRef]

239. Blaylock, M.G.; Cuthbertson, B.H.; Galley, H.F.; Ferguson, N.R.; Webster, N.R. The effect of nitric oxide and peroxynitrite on apoptosis in human polymorphonuclear leukocytes. Free Radic. Biol. Med. 1998, 25, 748-752. [CrossRef]

240. Wang, W.; Zhou, W.; Wu, S.; Liang, F.; Li, Y.; Zhang, J.; Cui, L.; Feng, Y.; Wang, Y. Perfluoroalkyl substances exposure and risk of polycystic ovarian syndrome related infertility in Chinese women. Envron. Pollut. 2019, 247, 824-831. [CrossRef]

241. Masjedi, F.; Keshtgar, S.; Zal, F.; Talaei-Khozani, T.; Sameti, S.; Fallahi, S.; Kazeroni, M. Effects of vitamin $\mathrm{D}$ on steroidogenesis, reactive oxygen species production, and enzymatic antioxidant defence in human granulosa cells of normal and polycystic ovaries. J. Ster. Biochem. Mol. Biol. 2020, 197, 105521. [CrossRef]

242. Di Nisio, A.; Rocca, M.S.; Sabovic, I.; De Rocco, M.; Corsini, P.C.; Guidolin, D.; Zanon, C.; Acquasaliente, L.; Carosso, A.R.; De Toni, L.; et al. Perfluorooctanoic acid alters progesterone activity in human endometrial cells and induces reproductive alterations in young women. Chemosphere 2020, 242, 125208. [CrossRef]

243. Taketani, T.; Tamura, H.; Takasaki, A.; Lee, L.; Kizuka, F.; Tamura, I.; Taniguchi, K.; Maekawa, R.; Asada, H.; Shimamura, K.; et al. Protective role of melatonin in progesterone production by human luteal cells. J. Pineal. Res. 2011, 51, 207-213. [CrossRef]

244. Mamsen, L.S.; Jonsson, B.A.G.; Lindh, C.H.; Olesen, R.H.; Larsen, A.; Ernst, E.; Kelsey, T.W.; Andersen, C.Y. Concentration of perfluorinated compounds in cotinine in human foetal organs, placenta, and maternal plasma. Sci. Tot. Environ. 2017, 596-597, 97-105. [CrossRef]

245. Sagiv, S.K.; Rifas-Shiman, S.L.; Fleisch, A.F.; Webster, T.F.; Calafat, A.M.; Ye, X.; Gillman, M.W.; Oken, E. Early-pregnancy plasma concentrations of perfluoroalkyl substances and birth outcomes in Project Viva: Confounded by pregnancy hemodynamics? Am. J. Epidemiol. 2018, 187, 793-802. [CrossRef]

246. Spratlen, M.J.; Perera, F.P.; Lederman, S.A.; Robinson, M.; Kannan, K.; Trasande, L.; Herbstman, J. Cord blood perfluoroalkyl substances in mothers exposed to the World Trade Center disaster during pregnancy. Environ. Pollut. 2020, 246, 482-490. [CrossRef] 
247. Midasch, O.; Drexler, H.; Hart, N.; Beckmann, M.W.; Angerer, J. Transplacental exposure of neonates to perfluorooctanesulfonate and perfluorooctanoate: A pilot study. Int. Arch. Occup. Environ. Health 2007, 80, 643-648. [CrossRef] [PubMed]

248. Fei, C.; McLaughlin, J.K.; Tarone, R.E.; Olsen, J. Perfluorinated chemicals and fetal growth: A study within the danish national birth cohort. Environ. Health Perspect. 2007, 115, 1677-1682. [CrossRef] [PubMed]

249. Winkens, K.V.R.; Berger, U.; Cousins, I. Early life exposure to per- and polyfluoroalkyl substances (PFAS): A critical review. Emer. Contamin. 2017, 3, 55-68. [CrossRef]

250. Huo, X.; Zhang, L.; Huang, R.; Feng, L.; Wang, W.; Zhang, J. Perfluoroalkyl substances exposure in early pregnancy and preterm birth in singleton pregnancies: A prospective cohort study. Environ. Health 2020, 19, 60. [CrossRef] [PubMed]

251. Trier, X.; Granby, K.; Christensen, J.H. Polyfluorinated surfactants (pfs) in paper and board coatings for food packaging. Environ. Sci. Pollut. Res. Int. 2011, 18, 1108-1120. [CrossRef]

252. Washino, N.; Saijo, Y.; Sasaki, S.; Kato, S.; Ban, S.; Konishi, K.; Ito, R.; Nakata, A.; Iwasaki, Y.; Saito, K.; et al. Correlations between prenatal exposure to perfluorinated chemicals and reduced fetal growth. Environ. Health Perspect. 2009, 117, 660-667. [CrossRef]

253. Bjerregaard-Olesen, C.; Bach, C.C.; Long, M.; Ghisari, M.; Bech, B.H.; Nohr, E.A.; Henriksen, T.B.; Olsen, J.; Bonefeld-Jørgensen, E.C. Determinants of serum levels of perfluorinated alkyl acids in Danish pregnant women. Int. J. Hyg. Environ. Health 2016, 219, 867-875. [CrossRef] [PubMed]

254. Brantsaeter, A.L.; Whitworth, K.W.; Ydersbond, T.A.; Haug, L.S.; Haugen, M.; Knutsen, H.K.; Thomsen, C.; Meltzer, H.M.; Becher, G.; Sabaredzovic, A.; et al. Determinants of plasma concentrations of perfluoroalkyl substances in pregnant Norwegian women. Environ. Int. 2013, 54, 74-84. [CrossRef]

255. Lewin, A.; Arbuckle, T.E.; Fisher, M.; Liang, C.L.; Marro, L.; Davis, K.; Abdelouahab, N.; Fraser, W.D. Univariate predictors of maternal concentrations of environmental chemicals: The MIREC study. Int. J. Hyg. Environ. Health 2017, 220, 77-85. [CrossRef] [PubMed]

256. Berg, V.; Nost, T.H.; Huber, S.; Rylander, C.; Hansen, S.; Veyhe, A.S.; Fuskevåg, O.M.; Odland, J.Ø.; Sandanger, T.M. Maternal serum concentrations of per-and polyfluoroalkyl substances and their predictors in years with reduced production and use. Environ. Int. 2014, 69, 58-66. [CrossRef] [PubMed]

257. Eriksson, U.; Mueller, J.F.; Toms, L.L.; Hobson, P.; Karrman, A. Temporal trends of PFSAs, PFCAs and selected precursors in Australian serum from 2002 to 2013. Environ. Pollut. 2017, 220, 168-177. [CrossRef]

258. Wilhelm, M.; Wittsiepe, J.; Volkel, W.; Fromme, H.; Kasper-Sonnenberg, M. Perfluoroalkyl acids in children and their mothers: Association with drinking water and time trends of inner exposures-results of the Duisburg birth cohort and Bochum cohort studies. Int. J. Hyg. Environ. Health 2015, 218, 645-655. [CrossRef]

259. Tsai, M.S.; Miyashita, C.; Araki, A.; Itoh, S.; Bamai, Y.A.; Goudarzi, H.; Okada, E.; Kashino, I.; Matsuura, H.; Kishi, R. Determinants and temporal trends of perfluoroalkyl substances in pregnant women: The Hokkaido study on Environment and Children's Health. Int. J. Environ. Res. Public Health 2018, 15, 989. [CrossRef] [PubMed]

260. de Cock, M.; de Boer, M.R.; Lamoree, M.; Legler, J.; van de Bor, M. Prenatal exposure to endocrine disrupting chemicals in relation to thyroid hormone levels in infants-A Dutch prospective cohort study. Environ. Health 2014, 13, 106. [CrossRef]

261. Johnson, P.I.; Sutton, P.; Atchley, D.S.; Koustas, E.; Lam, J.; Sen, S.; Robinson, K.A.; Axelrad, D.A.; Woodruff, T.J.; Sutton, P.; et al. The navigation guide-evidence-based medicine meets environmental health: Systematic review of non-human evidence for PFOA effects on fetal growth. Environ. Health Perspect. 2014, 122, 1040-1051. [CrossRef]

262. Bach, C.C.; Bech, B.H.; Brix, N.; Nohr, E.A.; Bonde, J.P.E.; Henriksen, T.B. Perfluoroalkyl and polyfluoroalkyl substances and human fetal growth: A systematic review. Crit. Rev. Toxicol. 2015, 45, 53-67. [CrossRef]

263. Liew, Z.; Ritz, B.; Bonefeld-Jorgensen, E.C.; Henriksen, T.B.; Nohr, E.A.; Bech, B.H.; Fei, C.; Bossi, R.; von Ehrenstein, O.S.; Streja, E.; et al. Prenatal exposure to perfluoroalkyl substances and the risk of congenital cerebral palsy in children. Am. J. Epidemiol. 2014, 180, 574-581. [CrossRef]

264. Jensen, T.K.; Andersen, L.B.; Kyhl, H.B.; Nielsen, F.; Christesen, H.T.; Grandjean, P. Association between perfluorinated compound exposure and miscarriage in Danish pregnant women. PLoS ONE 2015, 10, e0123496. [CrossRef] 
265. Apelberg, B.J.; Witter, F.R.; Herbstman, J.B.; Calafat, A.M.; Halden, R.U.; Needham, L.L.; Goldman, L.R. Cord serum concentrations of perfluorooctane sulfonate (PFOS) and perfluorooctanoate (PFOA) in relation to weight and size at birth. Environ. Health Perspect. 2007, 115, 1670-1676. [CrossRef]

266. Negri, E.; Metruccio, F.; Guercio, V.; Tosti, L.; Benfenati, E.; Bonzi, R.; La Vecchia, C.; Moretto, A. Exposure to PFOA and PFOS and fetal growth: A critical merging of toxicological and epidemiological data. Crit. Rev. Toxicol. 2017, 47, 482-508. [CrossRef]

267. Fei, C.; McLaughlin, J.K.; Tarone, R.E.; Olsen, J. Fetal growth indicators and perfluorinated chemicals: A study in the Danish National Birth Cohort. Am. J. Epidemiol. 2008, 168, 66-72. [CrossRef] [PubMed]

268. Dong, G.H.; Tung, K.Y.; Tsai, C.-H.; Liu, M.M.; Wang, D.; Liu, W.; Jin, Y.-H.; Hsieh, W.-S.; Lee, Y.L.; Chen, P.-C. Serum perfluoroalkyl concentrations, asthma outcomes, and immulogical markers in a case-control study of Taiwanese children. Environ. Health Perspect. 2013, 121, 507-513. [CrossRef]

269. Dong, G.H.; Liu, M.M.; Wang, D.; Zheng, L.; Liang, Z.F.; Jin, Y.-H. Sub-chronic effect of perfluorooctanesulfonate (PFOS) on the balance of type 1 and type 2 cytokine in adult C57BL6 mice. Arch. Toxicol. 2011, 85, 1235-1244. [CrossRef] [PubMed]

270. Humblet, O.; Diaz-Ramirez, L.G.; Balmes, J.R.; Pinney, S.M.; Hiatt, R.A. Perfluoroalkyl chemicals and asthma among children 12-19 years of age: NHANES (1999-2008). Environ. Health Perspect. 2014, 122, 1129-1233. [CrossRef] [PubMed]

271. Gruber, C.; Illi, S.; Lau, S.; Nickel, R.; Forster, J.; Kamin, W.; Bauer, C.-P.; Wahn, V.; Wahn, U. Transient suppression of atopy in early childhood is associated with high vaccination coverage. Pediatrics. 2003, 111, 282-288. [CrossRef]

272. Timmermann, C.A.; Rossing, L.I.; Grøntved, A.; Ried-Larsen, M.; Dalgård, C.; Andersen, L.B.; Grandjean, P.; Nielsen, F.; Svendsen, K.D.; Scheike, T.; et al. Adiposity and glycemic control in children exposed to perfluorinated compounds. J. Clin. Endocrinol. Metab. 2014, 99, E608-E614. [CrossRef]

273. Ovsyannikova, I.G.; Dhiman, N.; Jacobson, R.M.; Vierkant, R.A.; Poland, G.A. Frequency of measles virus-specific CD4+ and CD8+ T cells in subjects seronegative or highly seropositive for measles vaccine. Clin. Diagn. Lab. Immunol. 2003, 10, 411-416. [CrossRef]

274. Mora, A.M.; Fleisch, A.F.; Rifas-Shiman, S.L.; Baidal, J.A.W.; Pardo, L.; Webster, T.F.; Calafat, A.M.; Ye, X.; Oken, E.; Sagiv, S.K. Early life-exposure to per- and polyfluoroalkyl substances and mid-childhood lipid and alanine aminotransferase levels. Environ. Int. 2018, 111, 1-13. [CrossRef] [PubMed]

275. Olsen, G.W.; Butenhoff, J.L.; Zobel, L.R. Perfluoroalkyl chemicals and human fetal development: An epidemiologic review with clinical and toxicological perspectives. Reprod. Toxicol. 2009, 27, 212-213. [CrossRef]

276. Kudo, N.; Katakura, M.; Sato, Y.; Kawashima, Y. Sex hormone-regulated renal transport of perfluorooctanoic acid. Chem. Biol. Interact. 2002, 139, 301-316. [CrossRef]

277. Zhang, W.; Zhang, Y.; Taniyasu, S.; Yeung, L.W.Y.; Lam, P.K.S.; Wang, J.; Li, X.; Yamashita, N.; Dai, J. Distribution and fate of perfluoroalkyl substances in municipal wastewater treatment plants in economically developed areas in China. Environ. Pollut. 2013, 176, 10-17. [CrossRef]

278. Blake, B.E.; Pinney, S.M.; Hines, E.P.; Fenton, S.E.; Ferguson, K.K. Associations between longitudinal serum perfluoroalkyl substance (PFAS) levels and measures of thyroid hormone, kidney function, and body mass index in the Fernald Community Cohort. Environ. Pollut. 2018, 242, 894-904. [CrossRef]

279. Han, X.; Nabb, D.L.; Russell, M.H.; Kennedy, G.L.; Rickard, R.W. Renal elimination of perfluorocarboxylates (PFCAs). Chem. Res. Toxicol. 2012, 25, 35-46. [CrossRef] [PubMed]

280. Wolf, C.J.; Takacs, M.L.; Schmid, J.E.; Lau, C.; Abbott, B.D. Activation of mouse and human peroxisome proliferator-activated receptor alpha by perfluoroalkyl acids of different functional groups and chain lengths. Toxicol. Sci. 2008, 106, 162-171. [CrossRef]

281. Hagenaars, A.; Vergauwen, L.; Benoot, D.; Laukens, K.; Knapen, D. Mechanistic toxicity study of perfluorooctanoic acid in zebrafish suggests mitochondrial dysfunction to play a key role in PFOA toxicity. Chemosphere 2013, 91, 844-856. [CrossRef] [PubMed]

282. Stanifer, J.W.; Stapleton, H.M.; Souma, T.; Wittmer, A.; Zhao, X.; Boulware, L.E. Perfluorinated chemicals as emerging environmental threats to kidney health. A scoping review. Clin. J. Am. Soc. Nephrol. 2018, 13, 1479-1492. [CrossRef]

283. Basu, G.; Mohapatra, A. Interactions between thyroid disorders and kidney disease. Indian J. Endocrinol. Metab. 2012, 16, 204-213. [CrossRef] 
284. Verner, M.A.; Loccisano, A.E.; Morken, N.H.; Yoon, M.; Wu, H.; McDougall, R.; Maisonet, M.; Marcus, M.; Kishi, R.; Miyashita, C.; et al. Associations of perfluoroalkyl substances (PFAS) with lower birth weight: An evaluation of potential confounding by glomerular filtration rate using a physiologically based pharmacokinetic model (PBPK). Environ. Health Perspect. 2015, 123, 1317-1324. [CrossRef]

285. Bjork, J.; Butenhoff, J.; Wallace, K.J.T. Multiplicity of nuclear receptor activation by PFOA and PFOS in primary human and rodent hepatocytes. Toxicol. 2011, 288, 8-17. [CrossRef] [PubMed]

286. Rakhshandehroo, M.; Hooiveld, G.; Muller, M.; Kersten, S. Comparative analysis of gene regulation by the transcription factor PPAR $\alpha$ between mouse and human. PLoS ONE 2009, 4, e6796. [CrossRef] [PubMed]

287. Steenland, K.; Tinker, S.; Frisbee, S.; Ducatman, A.; Vaccarino, V. Association of perfluorooctanoic acid and perfluorooctane sulfonate with serum lipids among adults living near a chemical plant. Am. J. Epidemiol. 2009, 170, 1268-1278. [CrossRef] [PubMed]

288. Olsen, G.W.; Zobel, L.R. Assessment of lipid, hepatic, and thyroid parameters with serum perfluorooctanoate (PFOA) concentrations in fluorochemical production workers. Int. Arch. Occup. Environ. Health 2007, 81, 231-246. [CrossRef]

289. Steenland, K.; Savitz, T.F.; David, A. Epidemiologic evidence on the health effects of perfluorooctanoic acid (PFOA). Environ. Health Perspect. 2010, 118, 1100-1108. [CrossRef] [PubMed]

290. Dong, Z.; Wang, H.; Yu, Y.Y.; Li, Y.B.; Naidu, R.; Liu, R. Using 2003-2014 U.S. NHANES data to determine the associations between per- and polyfluoroalkyl substances and cholesterol: Trend and implications. Ecotoxicol. Environ. Saf. 2019, 173, 461-468. [CrossRef]

291. Nelson, J.W.; Hatch, E.E.; Webster, T.F. Exposure to polyfluoroalkyl chemicals and cholesterol, body weight, and insulin resistance in the general U.S. population. Environ. Health Perspect. 2010, 118, 197-202. [CrossRef] [PubMed]

292. Graber, J.M.; Alexander, C.; Laumbach, R.J.; Black, K.; Strickland, P.O.; Georgopoulos, P.G.; Marshall, E.G.; Shendell, D.G.; Alderson, D.; Mi, Z.; et al. Per and polyfluoroalkyl substances (PFAS) blood levels after contamination of a community water supply and comparison with 2013-2014 NHANES. J. Expo. Environ. Epidemiol. 2019, 29, 172-182. [CrossRef]

293. Jain, R.B.; Ducatman, A. Roles of gender and obesity in defining correlations between perfluoroalkyl substances and lipid/lipoproteins. Sci. Tot. Environ. 2019, 653, 74-81. [CrossRef]

294. Guruge, K.S.; Yeung, L.W.; Yamanaka, N.; Miyazaki, S.; Lam, P.K.; Giesy, J.P.; Jones, P.D.; Yamashita, N. Gene expression profiles in rat liver treated with perfluorooctanoic acid (PFOA). Toxicol. Sci. 2006, 89, 93-107. [CrossRef]

295. Pedersen, K.E.; Letcher, R.J.; Sonne, C.; Dietz, R.; Styrishave, B. Per- and polyfluoroalkyl substances (PFAS)-new endocrine disruptors in polar bears (Ursus maritimus)? Environ. Int. 2016, 96, 180-189. [CrossRef]

296. Scharmach, E.; Buhrke, T.; Lichtenstein, D.; Lampen, A. Perfluorooctanoic acid affects the activity of the hepatocyte nuclear factor 4 alpha (HNF4a). Toxicol. Lett. 2012, 212, 106-112. [CrossRef]

297. Hayhurst, G.P.; Lee, Y.H.; Lambert, G.; Ward, J.M.; Gonzalez, F.J. Hepatocyte nuclear factor 4a (nuclear receptor 2A1) is essential for maintenance of hepatic gene expression and lipid homeostasis. Mol. Cell. Biol. 2001, 21, 1393-1403. [CrossRef]

298. Rhee, J.; Inoue, Y.; Yoon, J.C.; Puigserver, P.; Fan, M.; Gonzalez, F.J.; Spiegelman, B.M. Regulation of hepatic fasting response by PPAR $\gamma$ coactivator-1a (PGC-1): Requirement for hepatocyte nuclear factor 4a in gluconeogenesis. Proc. Natl. Acad. Sci. USA 2003, 100, 4012-4017. [CrossRef]

299. Ohguchi, H.; Tanaka, T.; Uchida, A.; Magoori, K.; Kudo, H.; Kim, I.; Daigo, K.; Sakakibara, I.; Okamura, M.; Harigae, H.; et al. Hepatocyte nuclear factor 4a contributes to thyroid hormone homeostasis by cooperatively regulating the type 1 iodothyronine deiodinase gene with GATA4 and Krüppel like transcription factor 9. Mol. Cell. Biol. 2008, 28, 3917-3931. [CrossRef]

300. Sun, Q.; Zong, G.; Valvi, D.; Nielsen, F.; Coull, B.; Grandjean, P. Plasma concentrations of perfluoroalkyl substances and risk of Type 2 diabetes: A prospective investigation among U.S. women. Environ. Health Perspect. 2018, 126. [CrossRef] [PubMed]

301. Domazet, S.L.; Grøntved, A.; Timmermann, A.G.; Nielsen, F.; Jensen, T.K. Longitudinal associations of exposure to perfluoroalkylated substances in childhood and adolescence and indicators of adiposity and glucose metabolism 6 and 12 years later: The European Youth Heart Study. Diabetes Care 2016, 39, 1745-1751. [CrossRef] [PubMed] 
302. Su, T.C.; Kuo, C.C.; Hwang, J.J.; Lien, G.W.; Chen, M.F.; Chen, P.C. Serum perfluorinated chemicals, glucose homeostasis and the risk of diabetes in working-aged Taiwanese adults. Environ. Int. 2016, 88, 15-22. [CrossRef] [PubMed]

303. Lind, L.; Zethelius, B.; Salihovic, S.; van Bavel, B.; Lind, P.M. Circulating levels of perfluoroalkyl substances and prevalent diabetes in the elderly. Diabetologia 2014, 57, 473-479. [CrossRef] [PubMed]

304. Cardenas, A.; Gold, D.R.; Hauser, R.; Kleinman, K.P.; Hivert, M.F.; Calafat, A.M.; Ye, X.; Webster, T.F.; Horton, E.S.; Oken, E. Plasma concentrations of per- and polyfluoroalkyl substances at baseline and associations with glycemic indicators and diabetes incidence among high-risk adults in the diabetes prevention program trial. Environ. Health Perspect. 2017, 125, 107001. [CrossRef]

305. De Toni, L.; Radu, C.M.; Sabovic, I.; Di Nisio, A.; Dall'Acqua, S.; Guidolin, D.; Spampinato, S.; Campello, E.; Simioni, P.; Foresta, C. Increased cardiovascular risk associated with chemical sensitivity to perfluoro-octanoic acid: Role of impaired platelet aggregation. Int. J. Mol. Sci. 2020, 21, 399. [CrossRef]

306. Tang, J.; Lu, X.; Chen, F.; Ye, X.; Zhou, D.; Yuan, J.; He, J.; Chen, B.; Shan, X.; Jiang, J.; et al. Effects of perfluorooctanoic acid on the associated genes expression of autophagy signaling pathway of Carassius auratus lymphocytes in vitro. Front. Physiol. 2018, 9, 1748. [CrossRef]

307. Shi, X.; Zhou, B. The role of Nrf2 and MAPK pathways in PFOS-induced oxidative stress in zebrafish embryos. Toxicol. Sci. 2010, 115, 391-400. [CrossRef]

308. Du, J.; Cai, J.; Wang, S.; You, H. Oxidative stress and apotosis to zebrafish (Danio rerio) embryos exposed to perfluorooctane sulfonate (PFOS) and $\mathrm{ZnO}$ nanoparticles. Int. J. Occup. Med. Environ. Health 2017, 30, 213-229. [CrossRef]

309. Li, Y.; Men, B.; He, Y.; Xu, H.; Liu, M.; Wang, D. Effect of single-wall carbon nanotubes on bioconcentration and toxicity of perfluorooctane sulfonate in zebrafish (Danio rerio). Sci. Total Environ. 2017, 607-608, 509-518. [CrossRef] [PubMed]

310. Liu, H.; Sheng, N.; Zhang, W.; Dai, J. Toxic effects of perfluorononanoic acid on the development of Zebrafish (Danio rerio) embryos. J. Environ. Sci. 2015, 32, 26-34. [CrossRef] [PubMed]

311. Shi, G.; Xie, Y.; Guo, Y.; Dai, J. 6:2 fluorotelomer sulfonamide alkylbetaine (6:2 FTAB), a novel perfluorooctane sulfonate alternative, induced developmental toxicity in zebrafish embryos. Aquat. Toxicol. 2018, 195, $24-32$. [CrossRef]

312. Wu, Y.; Huang, J.; Deng, M.; Jin, Y.; Yang, H.; Liu, Y.; Cao, Q.; Mennigen, J.A.; Tu, W. Acute exposure to environmentally relevant concentrations of Chinese PFOS alternative F-53B induces oxidative stress in early developing zebrafish. Chemosphere 2019, 235, 945-951. [CrossRef] [PubMed]

313. Lee, J.W.; Choi, K.; Park, K.; Seong, C.; Yu, S.D.; Kim, P. Adverse effects of perfluoroalkyl acids on fish and other aquatic organisms: A review. Sci. Total Environ. 2020, 707, 135334. [CrossRef] [PubMed]

314. Rainieri, S.; Conlledo, N.; Langerholc, T.; Madorran, E.; Sala, M.; Barranco, A. Toxic effects of perfluorinated compounds at human cellular level and on a model vertebrate. Food Chem. Toxicol. 2017, 104, 14-25. [CrossRef]

315. Oakes, K.D.; Sibley, P.K.; Solomon, K.R.; Mabury, S.A.; Van der Kraak, G.J. Impact of perfluorooctanoic acid on fathead minnow (Pimephales promelas) fatty acyl-CoA oxidase activity, circulating steroids, and reproduction in outdoor microcosms. Environ. Toxicol. Chem. 2004, 23, 1912-1919. [CrossRef]

316. Garofalo, F.; Santovito, G.; Amelio, D. Morpho-functional effects of heat stress on the gills of Antarctic T. bernacchii and C. hamatus. Mar. Poll. Bull. 2019, 141, 194-204. [CrossRef]

317. Wu, Y.; Deng, M.; Jin, Y.; Liu, X.; Mai, Z.; You, H.; Mu, X.; He, X.; Alharthi, R.; Kostyniuk, D.J.; et al. Toxicokinetics and toxic effects of a Chinese PFOS alternative F-53B in adult zebrafish. Ecotoxicol. Environ. Saf. 2019, 171, 460-466. [CrossRef]

318. Wu, Y.; Deng, M.; Jin, Y.; Mu, X.; He, X.; Luu, N.T.; Yang, C.; Tu, W. Uptake and elimination of emerging polyfluoroalkyl substance F-53B in zebrafish larvae: Response of oxidative stress biomarkers. Chemosphere 2019, 215, 182-188. [CrossRef]

319. Briels, N.; Ciesielski, T.M.; Herzke, D.; Jaspers, V.L.B. Developmental toxicity of perfluorooctanesulfonate (PFOS) and its chlorinated polyfluoroalkyl ether sulfonate alternative F-53B in the domestic chicken. Environ. Sci. Technol. 2018, 52, 12859-12867. [CrossRef] [PubMed]

320. Cole, S.P.; Deeley, R.G. Transport of glutathione and glutathione conjugates by MRP1. Trends Pharmacol. Sci. 2006, 27, 438-446. [CrossRef] 
321. Houde, M.; Giraudo, M.; Douville, M.; Bougas, B.; Couture, P.; De Silva, A.O.; Spencer, C.; Lair, S.; Verreault, J.; Bernatchez, L.; et al. A multi-level biological approach to evaluate impacts of a major municipal effluent in wild St. Lawrence River yellow perch (Perca flavescens). Sci. Total Environ. 2014, 497-498, 307-318. [CrossRef] [PubMed]

322. Yang, J.H. Perfluorooctanoic acid induces peroxisomal fatty acid oxidation and cytokine expression in the liver of male Japanese medaka (Oryzias latipes). Chemosphere 2010, 81, 548-552. [CrossRef] [PubMed]

323. Ferro, D.; Bakiu, R.; De Pittà, C.; Boldrin, F.; Cattalini, F.; Pucciarelli, S.; Miceli, C.; Santovito, G. Cu,Zn superoxide dismutases from Tetrahymena thermophila: Molecular evolution and gene expression of the first line of antioxidant defenses. Protist 2015, 166, 131-145. [CrossRef] [PubMed]

324. Tilton, S.C.; Orner, G.A.; Benninghoff, A.D.; Carpenter, H.M.; Hendricks, J.D.; Pereira, C.B.; Williams, D.E. Genomic profiling reveals an alternate mechanism for hepatic tumor promotion by perfluorooctanoic acid in rainbow trout. Environ. Health Perspect. 2008, 116, 1047-1055. [CrossRef]

325. Costantini, D.; Blévin, P.; Herzke, D.; Moe, B.; Gabrielsen, G.W.; Bustnes, J.O.; Chastel, O. Higher plasma oxidative damage and lower plasma antioxidant defences in an Arctic seabird exposed to longer perfluoroalkyl acids. Environ. Res. 2019, 168, 278-285. [CrossRef] [PubMed]

326. Ferro, D.; Bakiu, R.; Pucciarelli, S.; Miceli, C.; Vallesi, A.; Irato, P.; Santovito, G. Molecular characterization, protein-protein interaction network, and evolution of four glutathione peroxidases from Tetrahymena thermophila. Antioxidants 2020, 9, 949. [CrossRef]

327. Franchi, N.; Ferro, D.; Ballarin, L.; Santovito, G. Transcription of genes involved in glutathione biosynthesis in the solitary tunicate Ciona intestinalis exposed to metals. Aquat. Toxicol. 2012, 114-115, 14-22. [CrossRef]

328. Arukwe, A.; Mortensen, A.S. Lipid peroxidation and oxidative stress responses of salmon fed a diet containing perfluorooctane sulfonic- or perfluorooctane carboxylic acids. Comp. Biochem. Physiol. C 2011, 154, 288-295. [CrossRef]

329. Wei, Y.; Chan, L.L.; Wang, D.; Zhang, H.; Wang, J.; Dai, J. Proteomic analysis of hepatic protein profiles in rare minnow (Gobiocypris rarus) exposed to perfluorooctanoic acid. J. Proteome Res. 2008, 7, 1729-1739. [CrossRef]

330. Wei, Y.; Liu, Y.; Wang, J.; Tao, Y.; Dai, J. Toxicogenomic analysis of the hepatic effects of perfluorooctanoic acid on rare minnows (Gobiocypris rarus). Toxicol. Appl. Pharmacol. 2008, 226, 285-297. [CrossRef]

331. Kim, S.; Stroski, K.M.; Killeen, G.; Smitherman, C.; Simcik, M.F.; Brooks, B.W. 8:8 Perfluoroalkyl phosphinic acid affects neurobehavioral development, thyroid disruption, and DNA methylation in developing zebrafish. Sci. Total Environ. 2020, 736, 139600. [CrossRef]

332. Collí-Dulá, R.C.; Martyniuk, C.J.; Streets, S.; Denslow, N.D.; Lehr, R. Molecular impacts of perfluorinated chemicals (PFAS) in the liver and testis of male largemouth bass (Micropterus salmoides) in Minnesota Lakes. Comp. Biochem. Physiol. D 2016, 19, 129-139. [CrossRef]

333. Lavut, A.; Raveh, D. Sequestration of highly expressed mRNAs in cytoplasmic granules, P-bodies, and stress granules enhances cell viability. PLoS Genet. 2012, 8, e1002527. [CrossRef]

334. Olszewska, M.; Bujarski, J.J.; Kurpisz, M. P-bodies and their functions during mRNA cell cycle: Mini-review. Cell Biochem. Funct. 2012, 30, 177-182. [CrossRef] [PubMed]

335. Nicorelli, E.; Gerdol, M.; Buonocore, F.; Pallavicini, A.; Scapigliati, G.; Guidolin, L.; Irato, P.; Corrà, F.; Santovito, G. First evidence of T cell restricted intracellular antigen (TIA) protein gene expression in Antarctic fish. Invert. Surviv. J. 2018, 15, 127.

336. Drago, L.; Ballarin, L.; Santovito, G. Stress granules in Ciona robusta: Molecular evolution of TIAR and TTP and early evidence of their gene expression under stress conditions induced by metals. Invert. Surviv. J. 2020, $17,12-13$.

337. Tolomeo, A.M.; Carraro, A.; Bakiu, R.; Toppo, S.; Gerdol, M.; Irato, P.; Pellegrino, D.; Garofalo, F.; Bisaccia, P.; Corrà, F.; et al. Too warm or not too warm... Is the antioxidant system of Antarctic fish ready to face climate changes? Invert. Surviv. J. 2020, 17, 11.

338. Wang, Z.; Cousins, I.T.; Scheringer, M.; Hungerbühler, K. Fluorinated alternatives to long-chain perfluoroalkyl carboxylic acids (PFCAs), perfluoroalkane sulfonic acids (PFSAs) and their potential precursors. Environ. Int. 2013, 60, 242-248. [CrossRef]

339. Wang, S.; Huang, J.; Yang, Y.; Hui, Y.; Ge, Y.; Larssen, T.; Yu, G.; Deng, S.; Wang, B.; Harman, C. First report of a Chinese PFOS alternative overlooked for 30 years: Its toxicity, persistence, and presence in the environment. Environ. Sci. Technol. 2013, 47, 10163-10170. [CrossRef] 
340. Munoz, G.; Liu, J.; Duy, S.V.; Sauvé, S. Analysis of F-53B, Gen-X, ADONA, and emerging fluoroalkylether substances in environmental and biomonitoring samples: A review. Trends Environ. Anal. Chem. 2019, 23, e00066. [CrossRef]

341. Xiao, F. Emerging poly-and perfluoroalkyl substances in the aquatic environment: A review of current literature. Water Res. 2017, 124, 482-495. [CrossRef] [PubMed]

342. Szilagyi, J.T.; Avula, V.; Fry, R.C. Perfluoroalkyl Substances (PFAS) and Their Effects on the Placenta, Pregnancy, and Child Development: A Potential Mechanistic Role for Placental Peroxisome Proliferator-Activated Receptors (PPARs). Curr. Environ. Health Rep. 2020, 7, 222-230. [CrossRef] [PubMed]

Publisher's Note: MDPI stays neutral with regard to jurisdictional claims in published maps and institutional affiliations.

(C) 2020 by the authors. Licensee MDPI, Basel, Switzerland. This article is an open access article distributed under the terms and conditions of the Creative Commons Attribution (CC BY) license (http://creativecommons.org/licenses/by/4.0/). 